\title{
Preliminary Performance Assessment for Disposal of APT and CLWR/TEF Wastes at SRS
}

by

E. L. Wilhite

Westinghouse Savannah River Company

Savannah River Site

Aiken, South Carolina 29808

L. B. Collard

J. R. Cook

R. A. Hane

T. Hang

DOE Contract No. DE-AC09-96SR18500

This paper was prepared in connection with work done under the above contract number with the U.S.

Department of Energy. By acceptance of this paper, the publisher and/or recipient acknowledges the U. S. Government's right to retain a nonexclusive, royalty-free license in and to any copyright covering this paper, along with the right to reproduce and to authorize others to reproduce all or part of the copyrighted paper. 
DISCLAIMER

This report was prepared as an account of work sponsored by an agency of the United States Government. Neither the United States Government nor any agency thereof, nor any of their employees, makes any warranty, express or implied, or assumes any legal liability or responsibility for the accuracy, completeness, or usefulness of any information, apparatus, product, or process disclosed, or represents that its use would not infringe privately owned rights. Reference herein to any specific commercial product, process, or service by trade name, trademark, manufacturer, or otherwise does not necessarily constitute or imply its endorsement, recommendation, or favoring by the United States Government or any agency thereof. The views and opinions of authors expressed herein do not necessarily state or reflect those of the United States Government or any agency thereof.

This report has been reproduced directly from the best available copy.

Available to DOE and DOE contractors from the Office of Scientific and Technical Information, P. O. Box 62, Oak Ridge, TN 37831; prices available from (423) 576-8401.

Available to the public from the National Technical Information Service, U. S. Department of Commerce, 5285.Port Royal Road, Springfield, VA 22161. 


\section{DISCLAIMER}

Portions of this document may be illegible in electronic image products. Images are produced from the best available original document. 
WESTINGHOUSE SAVANNAH RIVER COMPANY

SAVANNAH RIVER TECHNOLOGY CENTER

Derivative Classifier Le tetwers

Keywords: EAV

Environmental Transport

Pathways Analysis

Performance Assessment

WSRC-RP-98-01055

\section{PRELIMINARY PERFORMANCE ASSESSMENT}

FOR DISPOSAL OF APT AND CLWR/TEF WASTES AT SRS (U)

by
L.B. Collard
J.R. Cook
R.A. Hane
T. Hang
E.L. Wilhite

September 21, 1998 


\section{DISTRIBUTION}

W. E. Stevens, 773-A

J. R. Cook, 773-43A

E. L. Wilhite, 773-A

L. B. Collard, 773-43A

T. Hang, 773-42A

R.A. Hane, 773-43A

R. H. Hsu, 773-A

G.T. Chandler, 773-A

E.A. Clark, 773-A

R.M. Seaborn, 705-3C

P.I. Hudson, 705-3C

W. T. Goldston, 705-3C

M. J. Ades, 705-3C

D. F. Sink, 724-15E

L.C. Thomas, 705-3C

M.W. Lewis, 724-7E

R. W. Reynolds, 703-45A

J. L. England, LANL

S. O. Sheetz, LANL

J.S. Roberts, 703-45A

P.L. Nowacki, 730-1B

F.H. Brown, 730-1B

D.E. Grove, 730-1B

G.R. Vozniak, 730-1B

W.F. Brizes, 730-1B

S.S. Patel, 730-1B

J.R. Purucker, 730-1B

R. A. Smith, 730-1B

D. Morris, Burns \& Roe

C. Drewry, Burns \& Roe

A. Coons, Burns \& Roe

H. Shih, Burns \& Roe

P. Lanik, Burns \& Roe

G. DeCamp, Burns \& Roe

A. Ugelow, Burns \& Roe

H. Cohen, Burns \& Roe

K. Barbour, Burns \& Roe

M. Richards, GA-LANL

J.L. Anderson, LANL

SRTC Records (4), 773-52A 


\section{CONTENTS}

FIGURES.

TABLES

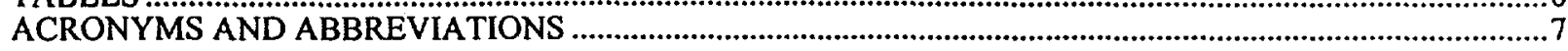

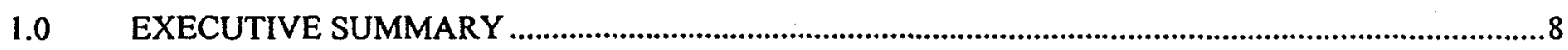

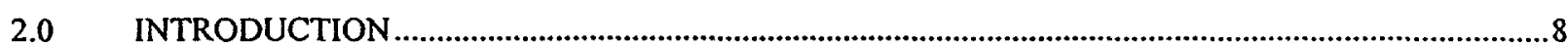

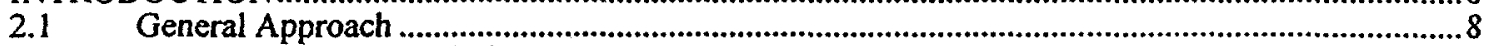

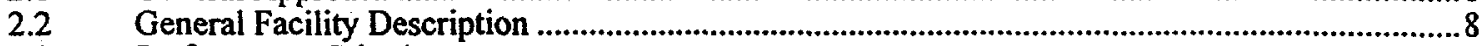

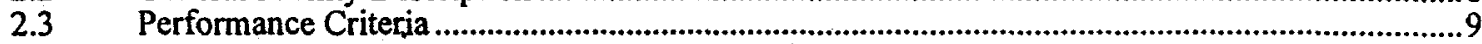

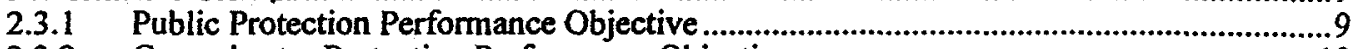

2.3.2 Groundwater Protection Performance Objective ........................................................10

2.3.3 Inadvertent Intruder Protection Performance Objective ........................................... 11

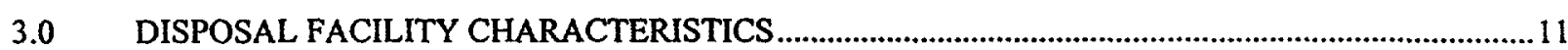

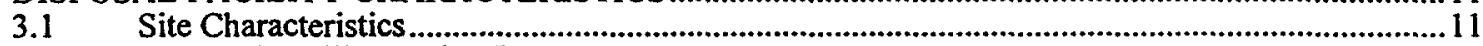

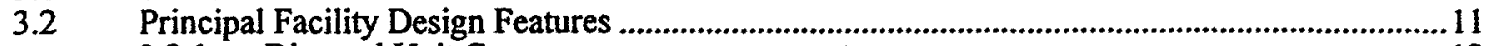

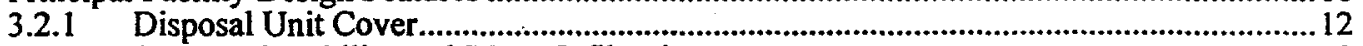

3.2.2 Structural Stability and Water Infiltration .........................................................12

Inadvertent Intruder Barrier ........................................................................ 12

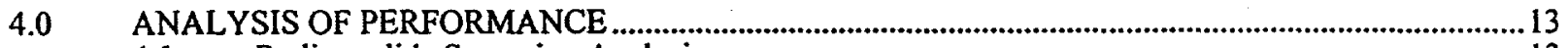

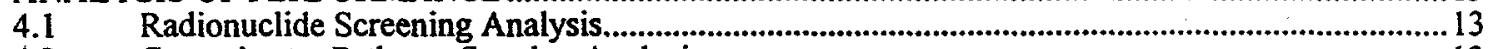

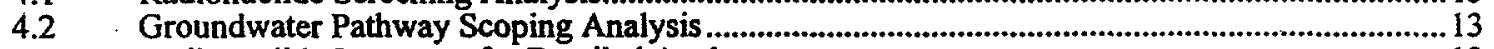

4.3 Radionuclide Inventory for Detailed Analyses ..................................................................13

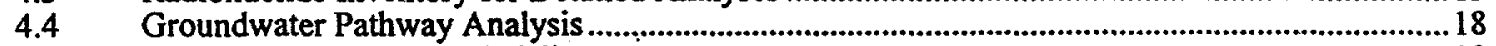

4.4.1 Vadose Zone Modeling ..........................................................................................18

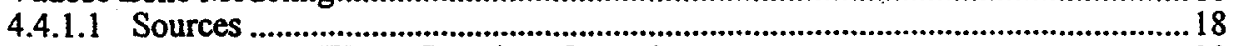

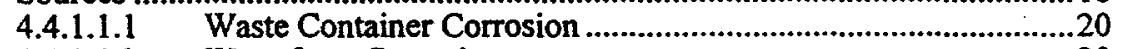

4.4.1.1.2 Wasteform Corrosion ..............................................................20

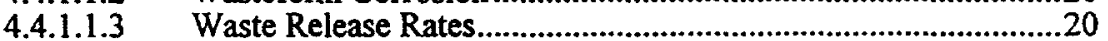

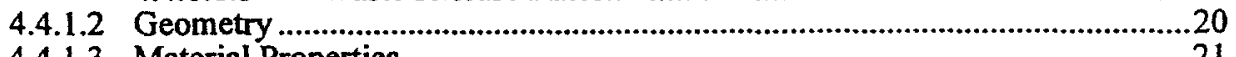

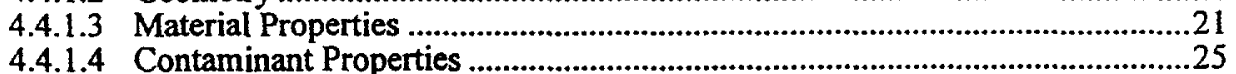

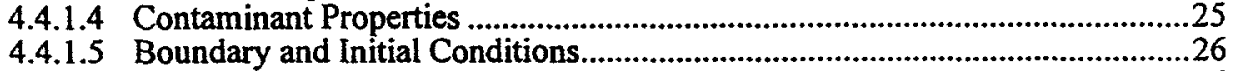

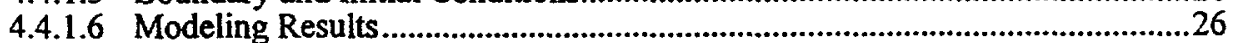

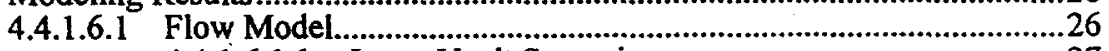

4.4.1.6.1.1 Intact Vault Scenario ................................................27

4.4.1.6.1.2 Cracked Vault Scenario...............................................27

4.4.1.6.1.3 Failed Vault Scenario ................................................ 30

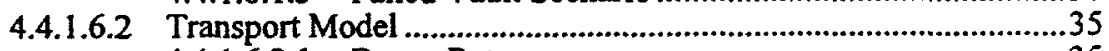

4.4.1.6.2.1 Decay Rate ..........................................................35

4.4.1.6.2.2 Retardation in the Vault ............................................... 35

4.4.1.6.2.3 Retardation in the Sediments................................. 36

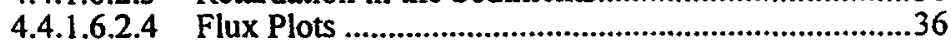

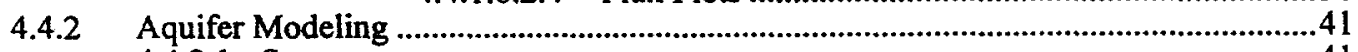

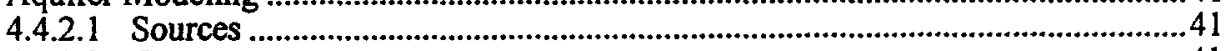

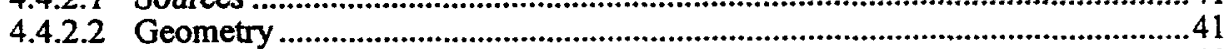

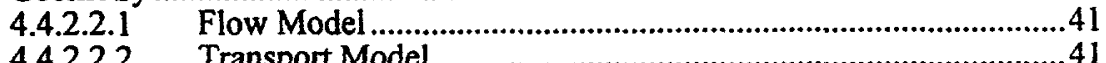

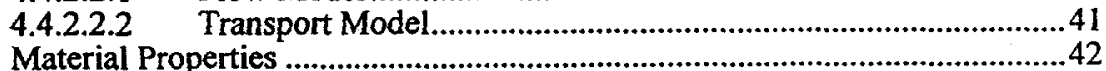

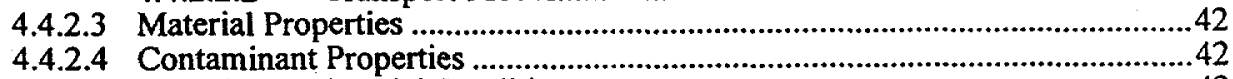

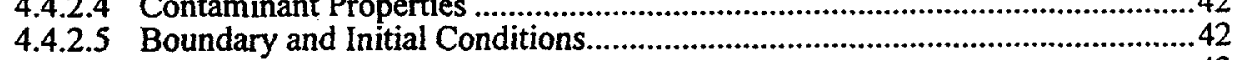

4.4.2.5.1 Flow Model ...................................................................42

4.4.2.5.2 Transport Model ........................................................................4. 42

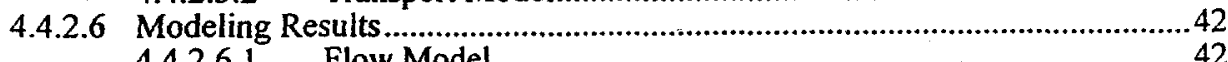

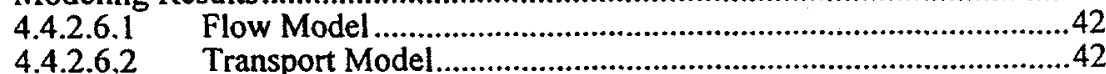

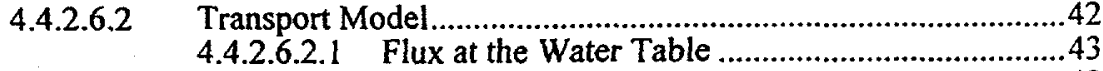

4.4.2.6.2.2 Decay Rate........................................................43

4.4.2.6.2.3 Retardation in the Aquifer .................................4 43

4.4.2.6.2.4 Normalized Concentration Plots................................44

4.4.3 Fractional Flux and Normalized Concentration Figures ........................................46 
4.5 Air Pathway Analysis

4.5.1 Tritium Wasteforms

69

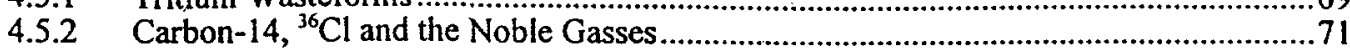

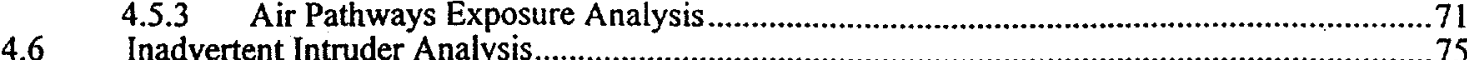

4.6.1 Exposure Scenarios for Inadvertent Intruders...........................................................

4.6.1.1 Chronic Exposure Scenarios for Inadvertent Intruders .................................75

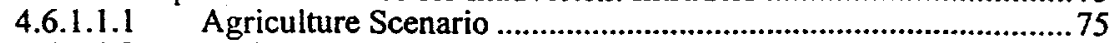

4.6.1.1.2 Resident Scenario ...................................................................75

4.6.1.1.3 Comparison of Agriculture and Resident Scenarios .....................76

4.6.1.1.4 Post-Drilling Scenario ..............................................................76

4.6.1.1.5 Comparison of Agriculture and Post-Drilling Scenarios..............77

4.6.1.2 Acute Exposure Scenarios for Intruders ...........................................................77

4.6.1.2.1 Construction Scenario ..................................................................77

4.6.1.2.2 Discovery Scenario ....................................................................77

4.6.1.2.3 Drilling Scenario ......................................................................78

4.6.1.2.4 Summary of Acute Exposure Scenarios..........................................78

4.6.1.3 Summary of Exposure Scenarios for Inadvertent Intruders ..............................78

4.6.2 Screening Of Radionuclides for Intruder Dose Analysis ....................................................78

4.6.3 Dose To Inadvertent Intruders ...........................................................................78

4.6.3.1 Dose Analysis for Agriculture Scenario

4.6.3.2 Dose Analysis for Resident Scenario.

4.6.3.3 Dose Analysis for Post-Drilling Scenario

4.6.4 Sensitivity and Uncertainty in Dose Models for Inadvertent Intruders ...............................

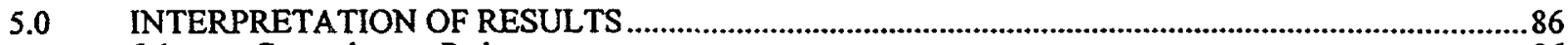

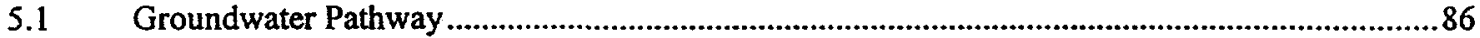

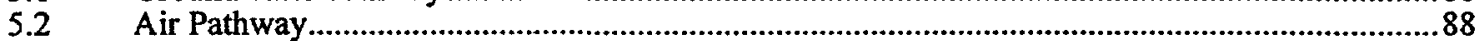

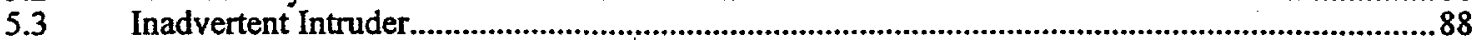

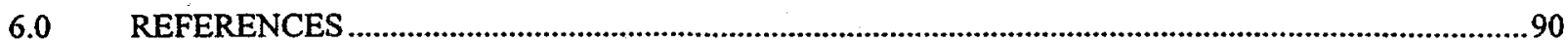




\section{FIGURES}

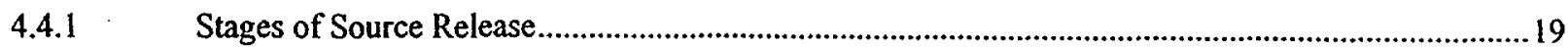

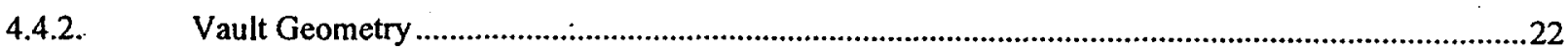

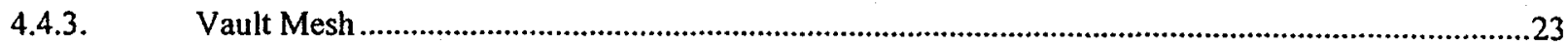

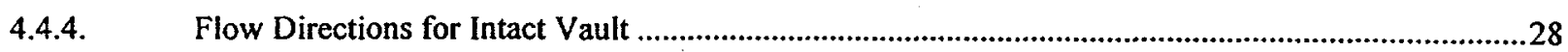

4.4.5. Velocity Flow Field and Streamlines with Time Markers for Intact Vault .......................................29

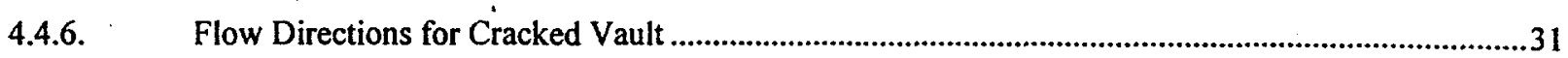

4.4.7. Velocity Flow Field and Streamlines with Time Markers for Cracked Vault....................................32

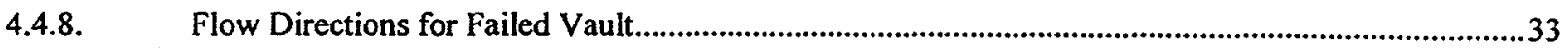

4.4.9. Velocity Flow Field and Streamlines with Time Markers for Failed Vauit .......................................34

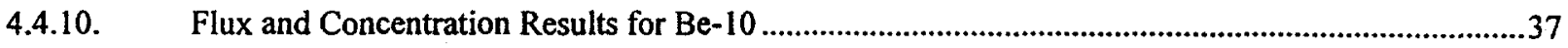

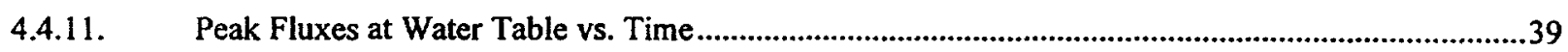

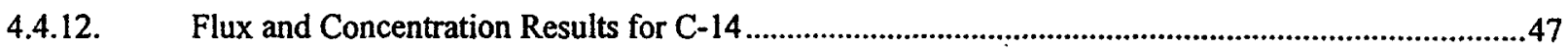

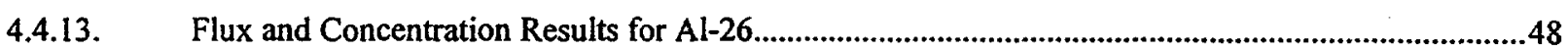

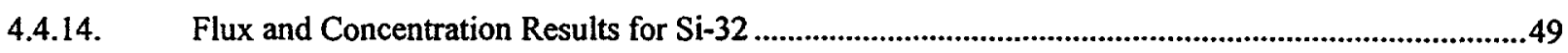

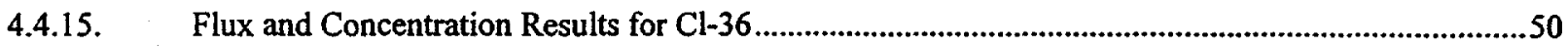

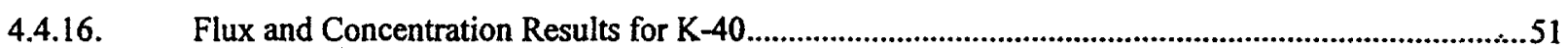

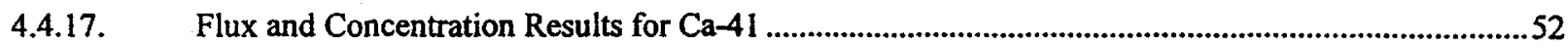

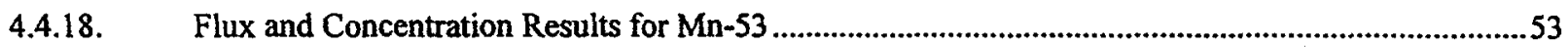

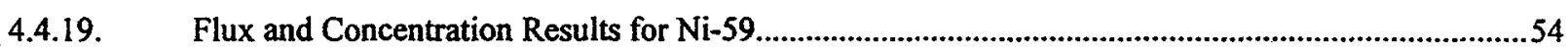

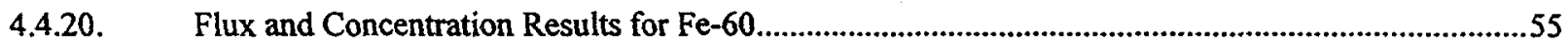

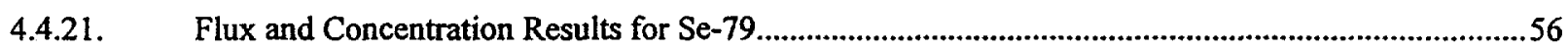

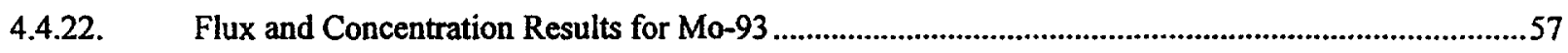

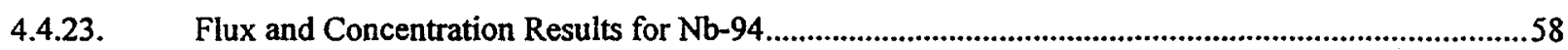

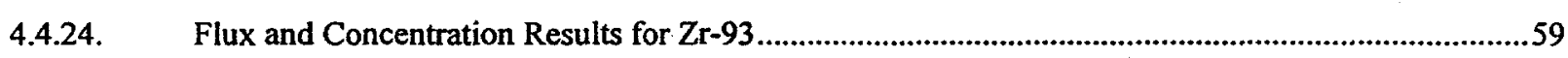

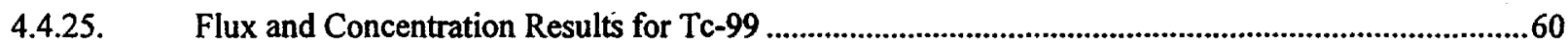

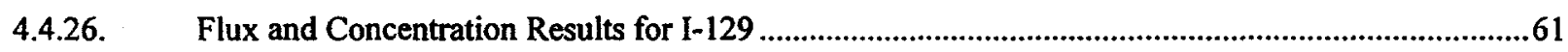

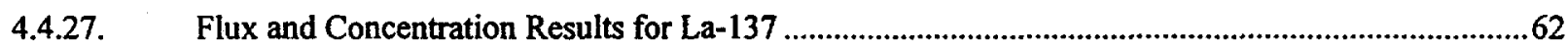

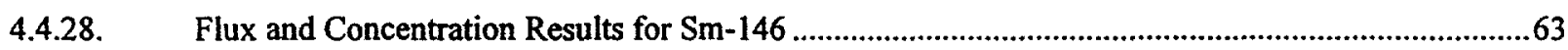

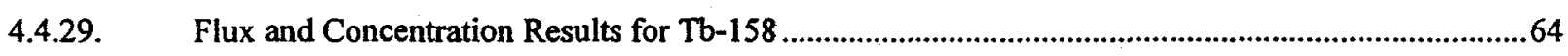

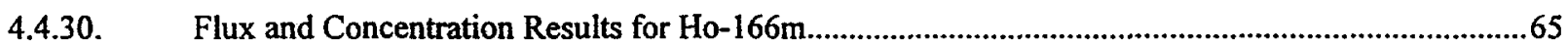

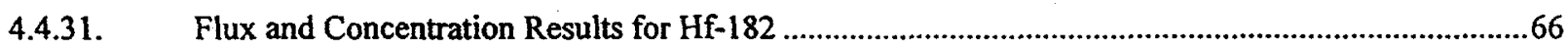

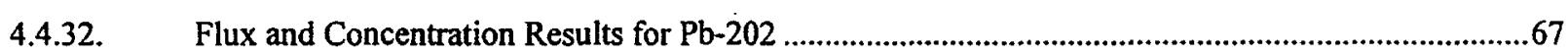

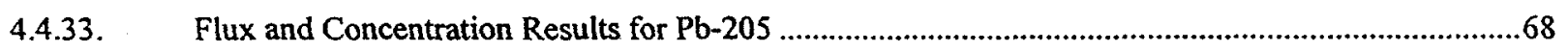




\section{TABLES}

2.3-1 Performance Measures and Points of Compliance ....................................................................... 10

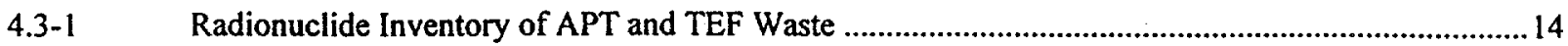

4.3-2 Total Project Inventory of APT and TEF Waste

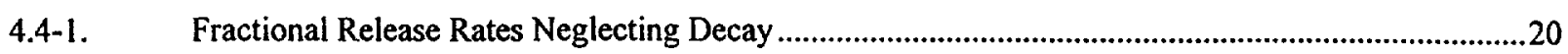

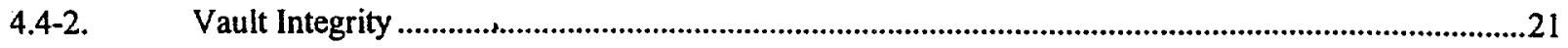

4.4-4. Selected Input Parameter Ranges from the Literature .................................................................21

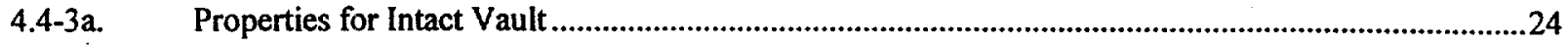

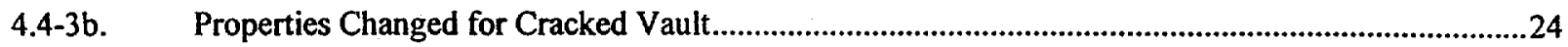

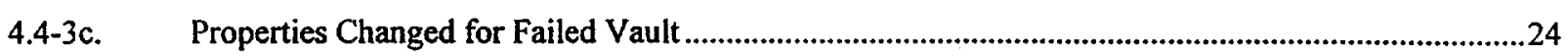

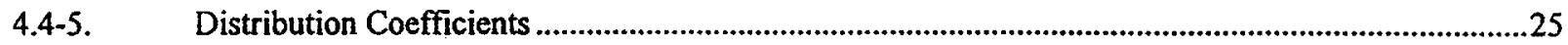

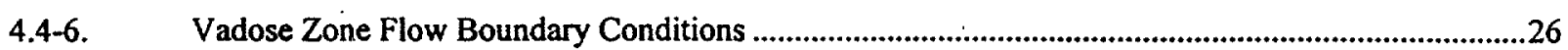

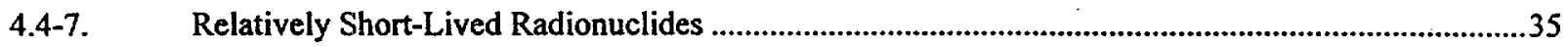

4.4-8. Radionuclides with Little Retardation in the Vault .......................................................................36

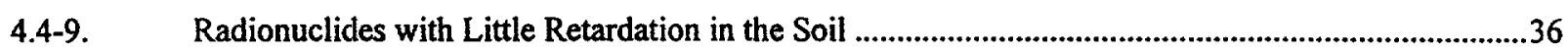

4.4-10. Peak Fluxes at Water Table versus Times..........................................................................................38

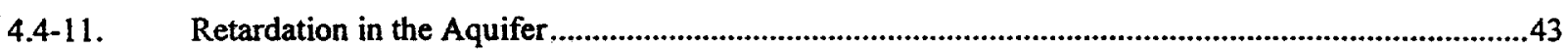

4.4-12. Peak Fractional Fluxes and Normalized Concentrations versus Time ................................................45

4.5-1. Input Parameters Used for APT Waste Container Tritium Permeation Calculation ............................69

4.5-2. Input Parameters Used for TEF Waste Container Tritium Permeation Calculation............................70

4.5-3. Tritium permeation calculation results..............................................................................................70

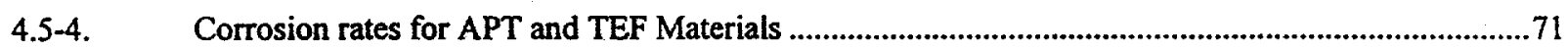

4.5.5. Release fractions for $\mathrm{C}-14, \mathrm{Cl}-36$, and noble gasses from APT and TEF wasteforms.......................71

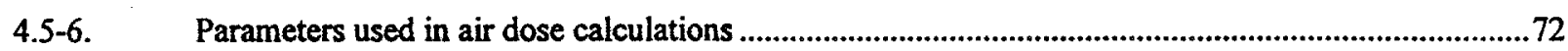

4.5-7. Dose factors for the air pathway......................................................................................................

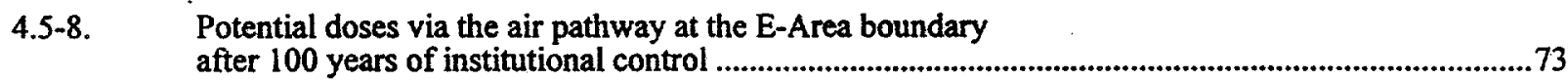

4.5-9. Potential doses via the air pathway at the SRS boundary ..................................................................74

4.5-10. Maximum dose via the air pathway ..................................................................................................74

4.5-11. Combined maximum doses for the air pathway for APT LLW, APT Lead,

4.6.3-1 Intruder Scenario Dose Conversion Factors

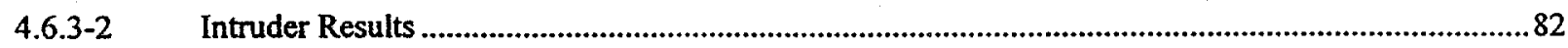

4.6.4-1 Parameters used in calculating SDCFs for Intruder dose analyses, by exposure scenario ...................85

5.1-1 Projected Maximum Groundwater Concentrations and MCLs ........................................................... 86

5.1-2 Ratio of Projected Maximum Groundwater Concentration to MCL ...............................................87

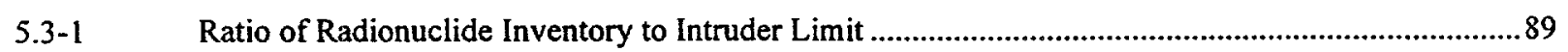




\section{ACRONYMS AND ABBREVIATIONS}

$\begin{array}{ll}\text { ALARA } & \text { As Low As reasonably Achievable } \\ \text { APT } & \text { Accelerator Production of Tritium } \\ \text { CERCLA } & \text { Comprehensive Environmental Response, Compensation, and Liability Act } \\ \text { DOE } & \text { Department of Energy } \\ \text { EDE } & \text { Effective Dose Equivalent } \\ \text { EH } & \text { DOE Office of Environment, Safety, and Health } \\ \text { EPA } & \text { Environmental Protection Agency } \\ \text { FY } & \text { Fiscal Year } \\ \text { GSA } & \text { General Separations Area } \\ \text { HTO } & \text { Tritiated Water Vapor } \\ \text { HT } & \text { Tritiated Hydrogen } \\ \text { ICRP } & \text { International Commission on Radiological Protection } \\ \text { ILNTV } & \text { Intermediate Level non-Tritium Vault } \\ \text { ILTV } & \text { Intermediate Level Tritium Vault } \\ \text { ILV } & \text { Intermediate Level Vaults } \\ \text { LLW } & \text { Low-level radioactive waste } \\ \text { LLWF } & \text { E-Area low-level waste facility } \\ \text { MCL } & \text { Maximum Contaminant Level } \\ \text { NPL } & \text { National Priority List } \\ \text { NRC } & \text { Nuclear Regulatory Commission } \\ \text { PA } & \text { Performance Assessment } \\ \text { PNNL } & \text { Pacific Northwest National Laboratory } \\ \text { SCDF } & \text { Scenario Dose Conversion Factor } \\ \text { SRS } & \text { Savannah River Site } \\ \text { TEF } & \text { Commercial Light Water Reactor/Tritium Extraction Facility } \\ \text { TPBAR } & \text { Tritium Producing Burnable Absorber Rod } \\ \text { UTR } & \text { Upper Three Runs } \\ \text { WAC } & \text { Waste Acceptance Criteria } \\ \text { WSRC } & \text { Westinghouse Savannah River Company } \\ & \end{array}$


The Department of Energy is considering two alternative processes for the future production of tritium for defense purposes. These are the Accelerator Production of Tritium and the Commercial Light Water Reactor/Tritium Extraction Facility projects. A preliminary performance assessment has been completed to assess the potential for disposal of low-level radioactive waste expected to arise from these processes in the E-Area low-level waste facility at the Savannah River Site.

Results indicate that the Accelerator Production of Tritium low-level wasteforms evaluated (i.e., Tungsten, Window, Steel, and Aluminum) and the Commercial Light Water Reactor/Tritium Extraction Facility waste evaluated (i.e., Tritium Producing Burnable Absorber Rods and baseplates) can be disposed in the E-Area low-level waste facility at the Savannah River Site.

The Accelerator Production of Tritium mixed-waste lead was also evaluated, even though the Savannah River Site has no plans to develop the capability for mixed-waste disposal. The conclusion of this preliminary performance assessment is that the Accelerator Production of Tritium lead wasteform, based solely on its radionuclide content, is not acceptable for disposal at the Savannah River Site.

\subsection{INTRODUCTION}

This section provides the descriptive information for understanding the analyses presented in this preliminary performance assessment (PA). This section addresses the approach taken in the PA, provides a general description of the Savannah River Site (SRS) E-Area low-level waste facility (LLWF), and discusses the performance criteria used for evaluating performance.

\subsection{General Approach}

Site-specific PAs are required by U.S. Department of Energy (DOE) Order $5820.2 \mathrm{~A}^{1.2}$ for the disposal of low-level radioactive waste (LLW) at DOE facilities. The purpose of this preliminary PA is to assess the potential for disposal of LLW expected to arise from facilities being considered for the future production of tritium for defense purposes at SRS. The facilities are the Accelerator Production of Tritium (APT) and the Commercial Light Water Reactor/Tritium Extraction Facility (TEF). These facilities are in the early project stage. Prior to construction of the facility selected for future tritium production, a more rigorous PA must be done to develop waste acceptance criteria (WAC) for these specific wastes unless the wastes conform to the WAC in force at that time.

The PA for the LLWF was originally published in 1994. The LLWF PA is now being revised. This preliminary PA for the APT and TEF wastes is based on the analysis methodology used in the revised LLWF PA ${ }^{3}$.

Details of wasteform and radionuclide inventory were extracted from current project documentation $n^{4}$, 6, 7, 8, 9. Due to the expected intense radiation field associated with the wastes, we assumed that all of the waste would be disposed in the Intermediate Level Vaults (ILV). We assumed that the waste would be contained in steel boxes that are welded shut after the waste is emplaced. The approach taken to the analysis methodology (e.g., radionuclide screening, groundwater flow and transport modeling, intruder analysis) is the same as in the revised LLWF PA.

\subsection{General Facility Description}

The LLWF is located near the center of the Savannah River Site, adjacent to the formerly used LLW burial grounds. Although the LLWF facility includes several types of disposal units (e.g., trenches, low-activity waste vaults, intermediate activity vaults), this preliminary PA only considers the intermediate level vaults (ILV).

The ILV is described in detail in the revised LLWF PA. There are two types of ILV, that for non-tritium waste (ILNTV) and that for tritium waste (ILTV). The ILTV has two types of cell, a cell for bulk waste that is the same as the cells in the ILNTV, and a cell comprised of vertical silos for tritium extraction crucibles. For the purposes of this preliminary PA we modeled all the APT and TEF wastes as if they were disposed in the bulk cell of the ILTV. The Tritium Producing Burnable Absorber Rods (TPBARS) from the TEF will probably be disposed in the ILTV silos. However, modeling them as being disposed in the bulk ILTV cell was judged to be appropriate for this preliminary PA.

Basically, the ILTV bulk cell is a below-grade concrete structure open at the top. Waste containers are placed into the cell by overhead crane. When the bottom of the cell is filled with waste containers, grout is poured around and over the containers and allowed to cure to provide a new working surface. When the cell is filled with waste a permanent concrete roof will be built. When all of the cells have been filled, constructing a multi-layered cap to divert infiltrating water will close the vault. 


\subsection{Performance Criteria}

The specific performance objectives for low-level radioactive waste disposal are contained in DOE Order 5820.2A ':

1. Protect public health and safety in accordance with standards specified in applicable EH Orders and other DOE Orders.

2. Assure that external exposure to the waste and concentrations of radioactive material which may be released to surface water, groundwater, soil, plants, and animals results in an effective dose equivalent (EDE) that does not exceed $25 \mathrm{mrem}$ per year to a member of the general public. Releases to the atmosphere shall meet the requirements of 40 CFR 61 which limits the EDE to 10 mrem per year. Reasonable effort should be made to maintain releases of radioactivity in effluent to the general environment ALARA.

3. Assure that the EDE from all exposure pathways received by individuals who inadvertently may intrude into the facility after the loss of active institutional control (100 years) will not exceed 100 mrem per year for continuous exposure or $500 \mathrm{mrem}$ for a single acute exposure.

4. Protect groundwater resources, consistent with Federal, State, and local requirements.

DOE Order 5820.2A is in the process of being revised. The revised Order will be DOE 435.1, which is expected to be issued in FY'99. In October 1996, DOE issued interim guidance for performance assessment ${ }^{2}$. This guidance clarifies the interpretation of the performance objectives in DOE Order 5820.2A. Table A-1 of the interim guidance, which is reproduced here as Table 2.3-1, delineates the specific performance measures for performance assessments.

According to the interim guidance, the point of compliance for protection of the public and water resources should be at the projected land-use boundary that separates land controlled by DOE (or other Federal agency) from land accessible to the general public. The new DOE Order, DOE 435.1, is expected to require use of a default point of compliance, outside a 100-m buffer zone around the disposed waste, where the projected dose or concentration is highest.

The interim guidance also states that the Performance assessment is to demonstrate a reasonable expectation of meeting the applicable performance objectives for the period from closure of the disposal facility to 1000 years post-closure. Calculation of doses or water concentrations at times later than 1000 years may be of interest, for the purpose of sensitivity or uncertainty analysis. The new Order, DOE 435.1, is expected to require the presentation of the maximum calculated impacts (e.g., dose, concentration) and the time they are calculated to occur, as part of the sensitivity analysis.

Due to the uncertainty regarding future point and time of compliance requirements, a more conservative approach than that required by the interim guidance has been taken in this preliminary PA. The point of compliance is taken to be that location more than 100-m from any disposed waste at which the projected dose or projected concentrations of contaminants in groundwater are the highest. The performance objectives for protection of off-site members of the public, inadvertent intruders, and groundwater resources are applied for 10,000 years after disposal. The 10,000-year period was selected to be consistent with PA guidance from the Nuclear Regulatory Commission ${ }^{10}$.

Compliance with the performance objective to protect water resources is interpreted at SRS as meaning that concentrations of radioactive contaminants at any points of compliance should not exceed standards for public drinking water supplies established by the Environmental Protection Agency (EPA).

Specific interpretation and application of the performance objectives listed above are further discussed below with respect to protection of the public, water resources, and inadvertent intruders.

\subsubsection{Public Protection Performance Objective}

Protection of the public according to the stated performance objectives requires that calculated annual dose to a hypothetical future member of the public shall not exceed $25 \mathrm{mrem}$ total effective dose equivalent (EDE) from all exposure pathways. "All exposure pathways" includes all modes of exposure, including the air pathway, but excluding exposures to radon and short-lived progeny. Furthermore, calculated dose via the air pathway is not to exceed $10-\mathrm{mrem} / \mathrm{yr}$. total EDE, again excluding dose from radon and short-lived progeny. The $10-\mathrm{mrem} / \mathrm{yr}$. limit, from 40 CFR 61 , is applicable to all sources, not just the E-Area LLWF. Therefore, the presence of other potential sources should be considered. The point of compliance, as stated earlier, is the point of highest calculated dose beyond a 100-meter buffer zone surrounding the waste.

Radon is addressed separately, with separate applicable limits. The wastes being assessed here do not contain radon or radon-producing radionuclides. 


\begin{tabular}{|c|c|c|}
\hline Component & Measure & Point of Compliance \\
\hline All pathways & $\begin{array}{l}\leq 25 \mathrm{mrem} \text { in a year, not including } \\
\text { doses from radon and progeny }\end{array}$ & Land-use boundary \\
\hline \multirow{3}{*}{ Air pathway } & $\begin{array}{l}\leq 10 \mathrm{mrem} \text { in a year, not including } \\
\text { doses from radon and progeny }\end{array}$ & Land-use boundary \\
\hline & $\begin{array}{l}\text { For radon- } 220 \text { and radon- } 222 \text {, either } \\
\text { (1) an average flux of } \leq 20 \mathrm{pCi} / \mathrm{m}^{2} / \mathrm{s} \text {, }\end{array}$ & Disposal facility surface \\
\hline & $\begin{array}{l}\text { Or, } \\
\text { (2) an air concentration of } \leq 0.5 \mathrm{pCi} / \mathrm{L} \\
\text { unless constrained by applicable } \\
\text { laws, regulations, or agreements }\end{array}$ & Land-use boundary \\
\hline \multirow[t]{2}{*}{$\begin{array}{l}\text { Hypothetical inadvertent } \\
\text { intruder }\end{array}$} & $\begin{array}{l}100 \text { mrem in a year from chronic } \\
\text { exposure, excluding radon and } \\
\text { progeny }\end{array}$ & Disposal facility \\
\hline & $\begin{array}{l}500 \text { mrem from a single event, } \\
\text { excluding radon and progeny }\end{array}$ & Disposal facility \\
\hline Groundwater protection & $\begin{array}{l}\text { Established consistent with laws, } \\
\text { agreements, or groundwater protection } \\
\text { management program }\end{array}$ & $\begin{array}{l}\text { Land-use boundary unless } \\
\text { constrained by applicable laws, } \\
\text { regulations, agreement, or } \\
\text { groundwater protection } \\
\text { management program and plan }\end{array}$ \\
\hline
\end{tabular}

\subsubsection{Groundwater Protection Performance Objective}

DOE Order 5820.2A and the interim guidance do not specify either dose or concentration limits for radionuclides in water. Therefore, there is some ambiguity in applying the performance objective even though, as described previously, the performance objective is interpreted as requiring that concentrations of contaminants in groundwater should not exceed values specified in EPA standards for public drinking water supplies".

In the revised PA for the E-Area Vault Facility ${ }^{3}$, three different options for specifying maximum contaminant levels (MCLs) of radionuclides in groundwater are considered. The three options, each of which is consistent with EPA standards for radioactivity in drinking water, are summarized below.

1) Current EPA standards for radionuclides in drinking water, including the method prescribed by the EPA for calculating MCLs for beta/gamma-emitting radionuclides based on internal dosimetry data from ICRP Publication and the specified MCLs for H-3 and Sr-90;

2) Current EPA standards for radionuclides in drinking water, except all MCLs for beta/gamma-emitting radionuclides are calculated from the prescribed dose limit using updated internal dosimetry data based on ICRP Publication 30; and

3) Proposed revisions of the EPA standards for radionuclides in drinking water, with MCLs for beta/gamma-emitting radionuclides calculated using internal dosimetry data based on ICRP Publication 30, except no standard for radon is assumed.

We used option 1 to assess compliance with the groundwater protection performance objective. The SRS is one of the DOE sites designated as being on the National Priority List (NPL) by the Comprehensive Environmental Response, Compensation, and Liability Act (CERCLA). As a result, all groundwater at SRS is regulated by CERCLA. Under CERCLA, the MCLs promulgated under the Safe Drinking Water Act are used as applicable or relevant and appropriate requirements (ARARs). Thus, even though they use out-dated dose methodology, the 
current MCLs (Option 1) should be used for compliance. Where the current MCLs do not specify a limit, we used the most restrictive limit derived from Options 2 and 3. In most, but not all, cases Option 1 produces the most restrictive MCLs.

\subsubsection{Inadvertent Intruder Protection Performance Objective}

Protection of persons who may inadvertently intrude into the E-Area LLWF requires that calculated annual total EDE to such individuals not exceed $100 \mathrm{mrem}$ for chronic exposure scenarios. For acute exposure scenarios, calculated doses are not to exceed 500-mrem total EDE. Institutional controls are assumed to be effective in deterring intrusion for at least 100 years following closure of the facility. Passive controls, in the form of engineered barriers or features of the site, can be claimed as further deterrents to intrusion.

In general, the chronic exposure scenarios address all reasonable pathways. Consumption of groundwater and contamination of crops by groundwater are exposure pathways that are excluded from the intruder analysis; impacts of groundwater contamination are evaluated separately in the PA in the all-pathways analysis and the water resource protection analysis.

\subsection{DISPOSAL FACILITY CHARACTERISTICS}

This section provides brief descriptions of the LLWF site, the principal design features of the facility, including the disposal unit cover, the structural stability of the closed facility and associated water infiltration, and the barrier to inadvertent intrusion. More detail is provided in reference 3.

\subsection{Site Characteristics}

The E-Area at the SRS, where the LLWF is located, consists of about 200 acres and is situated immediately north of the burial ground. The currently active disposal site is an elbow-shaped, cleared area of 100 acres in the center of the SRS. The site slopes from an elevation of 290 feet in the southernmost comer to an elevation of 250 feet in the northernmost corner. Runoff is to the north and east toward Upper Three Runs (UTR) creek and two of its ephemeral tributaries, Crouch Branch to the east of the LLWF and an unnamed branch to the west. UTR is about 2,500 feet north of the facility boundary. The nearest perennial stream is about 1,200 feet northeast of the boundary.

Groundwater flow directions in the uppermost aquifer (Aquifer Unit IIB) are northward toward discharge areas along Crouch Branch, UTR, and unnamed branch. Groundwater flow in this unit cannot move southward because of natural hydraulic gradients. Vertical flow is downward into Aquifer Unit IIA, which lies under Aquifer Unit IIB. Horizontal flow directions in Aquifer Unit IIA are directly toward UTR, which is the regional discharge zone for this unit in the vicinity of the LLWF. Aquifer Unit IIA is a zone of vertical-flow convergence. Groundwater flow is into the unit from both overlying and underlying aquifers. Natural groundwater gradients prevent the possibility of any contaminants migrating any deeper than Aquifer Unit IIA.

\subsection{Principal Facility Design Features}

The LLWF facility includes several types of disposal units (e.g., trenches, low-activity waste vaults, intermediate activity vaults, naval reactor component disposal). However, all of the wasteforms projected to arise from the APT and TEF facilities are expected to be classified as intermediate activity waste due to the external radiation field being greater than $200 \mathrm{mrem} / \mathrm{hour}$. Thus, this preliminary PA only considers the intermediate level vaults (ILV).

There are two types of ILV, that for non-tritium waste (ILNTV) and that for tritium waste (ILTV). The ILTV has two types of cell, a cell for bulk waste that is the same as the cells in the ILNTV, and a cell comprised of vertical silos for tritium extraction crucibles. For the purposes of this preliminary PA we modeled all the APT and TEF wastes as if they were disposed in the bulk cell of the ILTV. The Tritium Producing Bumable Absorber Rods (TPBARS) from the TEF will probably be disposed in the ILTV silos. However, modeling them as being disposed in the bulk ILTV cell was judged to be appropriate for this preliminary PA.

The ILTV is a subsurface concrete structure approximately $17-\mathrm{m}$ long, $15-\mathrm{m}$ wide, and $8.8-\mathrm{m}$ high. The end exterior walls are $0.8-\mathrm{m}$ thick, the side exterior walls are $0.6-\mathrm{m}$ thick, and interior walls are $0.5-\mathrm{m}$ thick. All walls are structurally mated to a base slab, which is $0.8-\mathrm{m}$ thick and extends past the outside of the exterior walls approximately $0.6 \mathrm{~m}$. The $0.8 \mathrm{-m}$ base slab rests on two layers of crushed stone placed on the compacted subsurface.

The floor of each cell slopes to a drain which runs to a sump in the base slab for each cell. Any water accumulating in the sump can be monitored and removed through a $0.15 \mathrm{~m}$-diameter riser pipe at the top of the wall. Any water that collects under the vault will flow to dry wells between the ILNTV and the ILTV. Access to the dry well is obtained through a manhole at grade level. 
Each cell is covered with reinforced concrete slabs, known as shielding tees, to reduce the radiation level at the edge of the vault. The profile of these tees is in the shape of the letter " $T$ " so that they can be interlocked to provide 0.5 $\mathrm{m}$ of shielding. Each cell is also provided with a metal rain cover that is installed over each cell when not operating to minimize the infiltration of rainwater.

Intermediate Activity Waste will be packaged in engineered metal or concrete containers that have been approved by Solid Waste Management. The containers will be remotely placed into the vault in layers. Containers will be grouted in place to provide better waste isolation, reduce dose to operators, and improve container stacking.

\subsubsection{Disposal Unit Cover}

Because closure of the LLWF will not occur for several years, a detailed closure design has not been fully developed. Rather a closure concept has been formulated for the purposes of the revised LLWF PA ${ }^{3}$. This closure concept is also used in this preliminary PA. The closure concept is described below.

Closure operations will begin when the vaults have been filled with waste and the concrete roof of the vault has been installed. At least $0.9-\mathrm{m}$ of backfill will be placed on the top of each vault. This layer of backfill will serve to establish slopes for the overlying layers so that infiltrating water will tend to flow down the slope and away from the vaults, limiting the amount of infiltration into the vault itself. Above this layer of backfill, a laterally extensive moisture barrier will be installed. This moisture barrier will consist of $0.76-\mathrm{m}$ of clay and an overlying layer of $0.3-$ $\mathrm{m}$ of gravel. A geotextile fabric will be placed on the gravel layer, and a second backfill layer, approximately 0.76$\mathrm{m}$ thick, will be placed over the moisture barrier. Finally, a $0.15-\mathrm{m}$ layer of topsoil will be placed on the top layer of backfill. This sequence of layers will provide a minimum of $2.9-\mathrm{m}$ of cover for each vault.

Final closure will be accomplished by constructing a drainage system and revegetating the site. The drainage system will consist of a system of riprap lined ditches that intercept the gravel layer of the moisture barrier. These ditches will divert surface runoff and water intercepted by the moisture barrier away from the disposal site. The drainage ditches will be constructed between rows of vaults and around the perimeter of the LLWF.

Bamboo, or some other vegetative cover, will be planted in the topsoil. Bamboo will quickly establish a dense ground cover that will prevent the growth of pine trees, the most deeply rooted naturally occurring plant type at SRS. Bamboo is a shallow-rooted climax species which evapotranspirates year-round in the SRS climate, thus, removing a large amount of moisture from the soil and decreasing the infiltration into the underlying disposal system. The dense ground cover provided by the bamboo will also limit soil erosion, contributing to the long-term integrity of the closure.

\subsubsection{Structural Stability and Water Infiltration}

The intermediate level tritium vaults will receive only containerized waste. The waste containers will be grouted into place within the vault. Thus, there will be minimal void space within the vault. Mechanisms for degradation of the vault were studied in the LLWF PA ${ }^{3}$. The results of this study defined three stages for the vaults. The initial stage, when all vault properties are the same as when the vaults were constructed, is termed the intact stage. The intact stage lasts for 575 years. The second stage is when the vault walls have through-wall cracks. The net water infiltration through the vaults in these stages is $4 \mathrm{~cm} /$ year. The cracked stage lasts for 475 years. The third stage is when the vault roof has lost sufficient strength to not be able to support the overburden. This stage is termed the failed stage. In the failed stage, we assume that the closure cap has been breached. Thus, the net water infiltration through the vaults in the failed stage is $40 \mathrm{~cm} /$ year.

\subsubsection{Inadvertent Intruder Barrier}

The SRS Future Use Plan ${ }^{15}$ indicates that the entire SRS will remain under Federal control for the indefinite future. However, because of the possibility of lapses of control, the potential impacts to a hypothetical individual who may inadvertently intrude into the LLWF must be determined. In this preliminary PA, we assumed that, for the first one hundred years following closure of the LLWF, no lapses of control would occur. Following this period, the structural integrity of the ILV will serve as an effective barrier to intrusion until the failed stage (1,050 years).

In the area surrounding the SRS, the types of drill bits normally used in constructing wells in the soft soils could not easily penetrate an intact concrete vault. Therefore, in attempting to drill directly through the disposal facility, it seems reasonable to assume that an intruder would encounter considerable resistance. Instead of taking extraordinary measures to obtain a drill bit designed to penetrate through hard rock, the intruder would move the drilling operation to a different location away from the disposal unit. Similarly, we assumed that an intruder carrying out activities to build a house could excavate to the top surface of the vault but during the first 1,050 years, would not take the steps necessary to penetrate to the waste. Rather, the intruder would use the top of the vault as a pad for constructing a house. 


\subsection{ANALYSIS OF PERFORMANCE}

This section presents the analysis of the performance of the APT and TEF wasteforms disposed in the Intermediate Level Tritium Vault. The analysis includes radionuclide screening, the scoping analysis for the groundwater pathway, the radionuclide inventory for the detailed analyses, and the detailed analysis of the groundwater pathway, the air pathway analysis and the intruder analysis.

\subsection{Radionuclide Screening Analysis}

The performance assessment process involves a series of iterative steps to consider the potential impacts of specific radionuclides and wasteforms on the environment and the public. Initially, very conservative (i.e., pessimistic) assumptions are made to construct simple models of radionuclide impact from disposed low-level waste (LLW). The purpose of the highly simplified calculations is to determine which radionuclides, environmental transport pathways, and exposure scenarios must be analyzed in more detail. This process involves screening and scoping calculations. Screening calculations utilize the most conservative assumptions and are intended to reduce a broad set of radionuclides, pathways, etc. to a relatively small set. Following screening, scoping calculations are performed on radionuclides requiring further analysis to determine which mitigating considerations may be necessary to produce acceptable results in the final calculations.

The screening process used initial, conservative estimates of the radionuclide inventory expected in the wastes, ${ }^{4.5}$. Radionuclide screening for the APT and TEF wastes ${ }^{12}$ considered a total of 826 radionuclides. Of these, the screening process demonstrates that, of the radionuclides expected to be in the APT and TEF wastes, only 56 must be considered further for the groundwater pathway, 64 for the inadvertent intruder, and 8 for the air pathway.

\subsection{Groundwater Pathway Scoping Analysis}

The purpose of the scoping analysis is to further reduce the number of radionuclides that need to be considered in a detailed analysis of the groundwater pathway. We selected a methodology ${ }^{13}$ that is more rigorous than that employed in the screening analysis described above. The methodology is still conservative enough that radionuclides shown to have minimal dose impact can be neglected with assurance that they would not have produced significant results if included in a detailed computer model. The groundwater pathway scoping analysis used the same conservative inventory used in the screening process. The scoping analysis reduced the number of radionuclides that need to be considered in the detailed groundwater analysis from 56 to 23 .

\subsection{Radionuclide Inventory for Detailed Analyses}

The radionuclide inventory used for the screening ${ }^{12}$ and scoping $^{13}$ analyses was obtained from earlier project documentation ${ }^{4.5}$. These documents provided a conservative (i.e., overstated) radionuclide inventory. Additionally, in developing the inventory for the TEF waste in the screening report ${ }^{2}$, the data from reference 5 was misinterpreted which increased the inventory for the baseplates by 38 times. This inventory was also used in the scoping analysis. However, for screening and scoping analyses, it is prudent to use conservative estimates of inventory.

For the detailed analyses, less conservative inventory estimates were used ${ }^{6,7,8,9}$. The final radionuclide inventory is presented in Tables 4.3-1 and 4.3-2 (only radionuclides that were not screened out are presented). Table 4.3-1 presents the radionuclide inventory of each APT and TEF wasteform after the current best estimate of interim storage. For APT waste, the interim storage is now assumed to be 10 years. For TEF waste, the interim storage period is assumed to be 90 days. The inventory presented for the tungsten, window and steel wasteforms is in curies expected to be produced per year. For the aluminum and lead waste, the inventory is in curies per cubic centimeter of waste. For the TEF wastes, Table 4.3-1 presents curies per TPBAR or baseplate.

Table 4.3-2 presents the total projected inventory over the project life of 40 years. For the APT wastes, the annual volume of waste expected to arise was obtained from reference 6. For the TEF wastes, a total of 4,200 TPBARS are projected to be produced per year and 250 baseplates are projected to be produced per year's. 


\begin{tabular}{|c|c|c|c|c|c|c|c|}
\hline & \multicolumn{5}{|c|}{ APT Waste } & \multicolumn{2}{|c|}{ TEF Waste } \\
\hline & Tungsten & Window & Steel & Aluminum & Lead & TPBAR & Baseplate \\
\hline Nuclide & $\mathrm{Ci} /$ year & $\mathrm{Ci} /$ year & $\mathrm{Ci} /$ year & $\mathrm{Ci} / \mathrm{cc}$ & $\mathrm{Ci} / \mathrm{cc}$ & Ci/TPBAR & Ci/Baseplate \\
\hline $\mathrm{H}-3$ & $6.00 \mathrm{E}+05$ & $2.00 \mathrm{E}+03$ & $2.00 \mathrm{E}+03$ & $2.95 \mathrm{E}-02$ & $5.63 \mathrm{E}-02$ & $1.14 \mathrm{E}+04$ & $1.81 \mathrm{E}-06$ \\
\hline $\mathrm{Be}-10$ & $4.00 \mathrm{E}-04$ & $2.00 \mathrm{E}-05$ & $2.00 \mathrm{E}-05$ & $7.10 \mathrm{E}-09$ & $5.81 \mathrm{E}-09$ & & \\
\hline $\mathrm{C}-14$ & $7.00 \mathrm{E}-02$ & $2.00 \mathrm{E}-02$ & $2.00 \mathrm{E}-02$ & $2.06 \mathrm{E}-06$ & $8.52 \mathrm{E}-06$ & $9.45 \mathrm{E}-03$ & $9.92 \mathrm{E}-03$ \\
\hline $\mathrm{Na}-22$ & $3.00 \mathrm{E}+02$ & $3.00 \mathrm{E}+01$ & $3.00 \mathrm{E}+01$ & $6.23 \mathrm{E}-03$ & $6.60 \mathrm{E}-04$ & & \\
\hline $\mathrm{Al}-26$ & $3.00 \mathrm{E}-02$ & $2.00 \mathrm{E}-03$ & $2.00 \mathrm{E}-03$ & $3.56 \mathrm{E}-06$ & $4.46 \mathrm{E}-07$ & & \\
\hline Si-32 & $3.00 \mathrm{E}+00$ & $4.00 \mathrm{E}-05$ & $4.00 \mathrm{E}-05$ & $3.04 \mathrm{E}-13$ & $4.88 \mathrm{E}-11$ & & \\
\hline $\mathrm{S}-35$ & $2.00 \mathrm{E}-15$ & $2.00 \mathrm{E}-10$ & $2.00 \mathrm{E}-10$ & $9.37 \mathrm{E}-25$ & $1.12 \mathrm{E}-18$ & $3.86 \mathrm{E}-03$ & \\
\hline $\mathrm{Cl}-36$ & $7.50 \mathrm{E}-02$ & $8.00 \mathrm{E}-03$ & $8.00 \mathrm{E}-03$ & $4.03 \mathrm{E}-18$ & $1.16 \mathrm{E}-08$ & & \\
\hline Ar-39 & $3.00 \mathrm{E}+01$ & $3.00 \mathrm{E}+00$ & $3.00 \mathrm{E}+00$ & $1.02 \mathrm{E}-12$ & $1.25 \mathrm{E}-06$ & $7.05 \mathrm{E}-03$ & \\
\hline Ar-42 & $4.00 \mathrm{E}+00$ & $3.00 \mathrm{E}-06$ & $3.00 \mathrm{E}-06$ & $3.01 \mathrm{E}-15$ & $1.30 \mathrm{E}-05$ & & \\
\hline $\mathrm{K}-40$ & $3.00 \mathrm{E}-05$ & $2.00 \mathrm{E}-06$ & $2.00 \mathrm{E}-06$ & $7.76 \mathrm{E}-17$ & $2.84 \mathrm{E}-11$ & & \\
\hline $\mathrm{Ca}-41$ & $3.00 \mathrm{E}-01$ & $2.00 \mathrm{E}-02$ & $2.00 \mathrm{E}-02$ & $3.66 \mathrm{E}-08$ & $2.99 \mathrm{E}-07$ & $4.53 \mathrm{E}-05$ & \\
\hline Sc-46 & $3.00 \mathrm{E}-15$ & $2.00 \mathrm{E}-10$ & $2.00 \mathrm{E}-10$ & $3.34 \mathrm{E}-18$ & $2.60 \mathrm{E}-17$ & $1.53 \mathrm{E}-03$ & \\
\hline $\mathrm{Ti}-44$ & $5.00 \mathrm{E}+01$ & $6.00 \mathrm{E}+00$ & $6.00 \mathrm{E}+00$ & $4.85 \mathrm{E}-18$ & & & \\
\hline$V-49$ & $5.00 \mathrm{E}+01$ & $3.00 \mathrm{E}+00$ & $3.00 \mathrm{E}+00$ & $9.21 \mathrm{E}-07$ & $2.62 \mathrm{E}-07$ & & \\
\hline Mn-53 & $4.00 \mathrm{E}-02$ & $1.00 \mathrm{E}-03$ & $1.00 \mathrm{E}-03$ & $1.05 \mathrm{E}-17$ & $3.37 \mathrm{E}-10$ & & \\
\hline $\mathrm{Fe}-60$ & $8.00 \mathrm{E}-04$ & $2.00 \mathrm{E}-05$ & $2.00 \mathrm{E}-05$ & $3.08 \mathrm{E}-14$ & $7.26 \mathrm{E}-10$ & & \\
\hline $\mathrm{Co}-60$ & $3.00 \mathrm{E}+04$ & $6.00 \mathrm{E}+01$ & $6.00 \mathrm{E}+01$ & $1.15 \mathrm{E}-05$ & $3.40 \mathrm{E}-05$ & $3.25 \mathrm{E}+01$ & $1.08 E+02$ \\
\hline $\mathrm{Ni}-59$ & $1.00 \mathrm{E}+01$ & $6.00 \mathrm{E}-02$ & $6.00 \mathrm{E}-02$ & $4.59 \mathrm{E}-08$ & $1.88 \mathrm{E}-11$ & $2.53 \mathrm{E}-02$ & $4.45 \mathrm{E}-02$ \\
\hline $\mathrm{Ni}-63$ & $3.66 \mathrm{E}-04$ & $4.00 \mathrm{E}+00$ & $4.00 \mathrm{E}+00$ & $2.90 \mathrm{E}-05$ & $2.95 \mathrm{E}-05$ & $4.10 \mathrm{E}+00$ & $4.82 \mathrm{E}+00$ \\
\hline $\mathrm{Ge}-68$ & $7.00 \mathrm{E}-02$ & $3.00 \mathrm{E}-03$ & $3.00 \mathrm{E}-03$ & & $2.14 \mathrm{E}-08$ & & \\
\hline Se-79 & $9.00 \mathrm{E}-03$ & $1.00 \mathrm{E}-07$ & $1.00 \mathrm{E}-07$ & & $8.94 \mathrm{E}-08$ & & \\
\hline $\mathrm{Kr}-81$ & $4.00 \mathrm{E}-02$ & $9.00 \mathrm{E}-04$ & $9.00 \mathrm{E}-04$ & & $1.30 \mathrm{E}-08$ & & \\
\hline $\mathrm{Kr}-85$ & $9.00 \mathrm{E}+00$ & $3.00 \mathrm{E}-05$ & $3.00 \mathrm{E}-05$ & & $6.54 \mathrm{E}-05$ & & \\
\hline $\mathrm{Rb}-87$ & $8.55 \mathrm{E}-16$ & $2.00 \mathrm{E}-14$ & $2.00 \mathrm{E}-14$ & & $5.77 \mathrm{E}-14$ & & \\
\hline Sr-90+d & $6.00 \mathrm{E}+00$ & $2.00 \mathrm{E}-06$ & $2.00 \mathrm{E}-06$ & & $9.36 \mathrm{E}-05$ & & \\
\hline $\mathrm{Zr}-93$ & $3.00 \mathrm{E}-03$ & $3.00 \mathrm{E}-05$ & $3.00 \mathrm{E}-05$ & & $2.95 \mathrm{E}-09$ & $1.46 \mathrm{E}-04$ & \\
\hline $\mathrm{Nb}-93 \mathrm{~m}$ & $3.00 \mathrm{E}+03$ & $1.00 \mathrm{E}+01$ & $1.00 \mathrm{E}+01$ & & $9.36 \mathrm{E}-07$ & $6.71 \mathrm{E}-06$ & \\
\hline $\mathrm{Nb}-94$ & $1.00 \mathrm{E}+01$ & $2.00 \mathrm{E}-02$ & $2.00 \mathrm{E}-02$ & & $1.12 \mathrm{E}-07$ & $3.76 \mathrm{E}-04$ & $1.02 \mathrm{E}-04$ \\
\hline Mo-93 & $6.00 \mathrm{E}+00$ & $3.00 \mathrm{E}-02$ & $3.00 \mathrm{E}-02$ & & $7.68 \mathrm{E}-07$ & $7.18 \mathrm{E}-04$ & $3.03 \mathrm{E}-04$ \\
\hline Tc-97 & $6.00 \mathrm{E}-03$ & $9.00 \mathrm{E}-11$ & $9.00 \mathrm{E}-11$ & & $9.12 \mathrm{E}-10$ & & \\
\hline Tc-98 & $8.00 \mathrm{E}-04$ & $2.00 \mathrm{E}-09$ & $2.00 \mathrm{E}-09$ & & $3.42 \mathrm{E}-10$ & & \\
\hline Tc-99 & $3.00 \mathrm{E}-01$ & $3.00 \mathrm{E}-04$ & $3.00 \mathrm{E}-04$ & & $3.16 \mathrm{E}-08$ & $1.88 \mathrm{E}-04$ & $2.33 \mathrm{E}-05$ \\
\hline Rh-101 & $9.00 \mathrm{E}+02$ & $2.00 \mathrm{E}-15$ & $2.00 \mathrm{E}-15$ & & $1.07 \mathrm{E}-04$ & & \\
\hline Rh-102m & $2.00 \mathrm{E}-03$ & $1.00 \mathrm{E}-17$ & $1.00 \mathrm{E}-17$ & & $5.23 \mathrm{E}-10$ & & \\
\hline Rh-102 & $3.00 \mathrm{E}+02$ & $4.00 \mathrm{E}-14$ & $4.00 \mathrm{E}-14$ & & $1.94 \mathrm{E}-05$ & & \\
\hline Pd-107 & $4.00 \mathrm{E}-04$ & & & & $7.56 \mathrm{E}-10$ & & \\
\hline $\mathrm{Ag}-108 \mathrm{~m}$ & $7.00 \mathrm{E}-02$ & & & & $1.23 \mathrm{E}-08$ & & \\
\hline $\mathrm{Cd}-113 \mathrm{~m}$ & $3.00 \mathrm{E}-01$ & & & & $5.00 \mathrm{E}-08$ & & \\
\hline $\mathrm{Cd}-113$ & $2.00 \mathrm{E}-19$ & & & & & & \\
\hline
\end{tabular}




\begin{tabular}{|c|c|c|c|c|c|c|c|}
\hline & \multicolumn{5}{|c|}{ APT Waste } & \multicolumn{2}{|c|}{ TEF Waste } \\
\hline & Tungsten & Window & Steel & Aluminum & Lead & TPBAR & Baseplate \\
\hline Nuclide & $\mathrm{Ci} /$ year & Ci/year & $\mathrm{Ci} /$ year & $\mathrm{Ci} / \mathrm{cc}$ & $\mathrm{Ci} / \mathrm{cc}$ & $\mathrm{Ci} / \mathrm{TPBAR}$ & Ci/Baseplate \\
\hline In-115 & $8.00 \mathrm{E}-18$ & & & & & & \\
\hline $\mathrm{Sn}-121 \mathrm{~m}$ & $4.00 \mathrm{E}-03$ & & & & 9.24E-07 & $3.21 \mathrm{E}-04$ & \\
\hline Sn-126 & $4.00 \mathrm{E}-16$ & & & & $8.46 \mathrm{E}-14$ & & \\
\hline $\mathrm{Te}-123$ & $4.00 \mathrm{E}-07$ & & & & $3.73 \mathrm{E}-17$ & & \\
\hline I-129 & $2.00 \mathrm{E}-06$ & & & & $3.31 \mathrm{E}-11$ & & \\
\hline $\mathrm{Xe}-127$ & & & & & $6.12 \mathrm{E}-34$ & & \\
\hline Cs-135 & $1.10 \mathrm{E}-05$ & & & & $2.75 \mathrm{E}-10$ & & \\
\hline Cs-137+d & $4.00 \mathrm{E}-05$ & & & & $1.03 \mathrm{E}-08$ & & \\
\hline Ba-133 & $3.00 \mathrm{E}+03$ & & & & $8.10 \mathrm{E}-05$ & $4.40 \mathrm{E}-04$ & \\
\hline La-137 & $3.00 \mathrm{E}+00$ & & & & $1.27 \mathrm{E}-08$ & & \\
\hline La-138 & $8.00 \mathrm{E}-13$ & & & & $6.90 \mathrm{E}-15$ & & \\
\hline $\mathrm{Pm}-145$ & $4.00 \mathrm{E}+03$ & & & & $3.74 \mathrm{E}-05$ & & \\
\hline $\mathrm{Sm}-146$ & $8.00 \mathrm{E}-04$ & & & & $3.02 \mathrm{E}-11$ & & \\
\hline Sm-147 & $7.00 \mathrm{E}-07$ & & & & $1.65 \mathrm{E}-14$ & & \\
\hline Sm-151 & $4.00 \mathrm{E}+00$ & & & & $4.74 \mathrm{E}-06$ & & \\
\hline Eu-150 & $1.00 \mathrm{E}+02$ & & & & $7.26 \mathrm{E}-06$ & & \\
\hline $\mathrm{Eu}-152$ & $4.00 \mathrm{E}+02$ & & & & $6.42 \mathrm{E}-06$ & & \\
\hline Eu-154 & $6.00 \mathrm{E}+01$ & & & & $2.45 \mathrm{E}-05$ & & \\
\hline Gd-148 & $9.00 \mathrm{E}+02$ & & & & $3.86 \mathrm{E}-05$ & & \\
\hline Gd-152 & $2.00 \mathrm{E}-14$ & & & & $5.02 \mathrm{E}-17$ & & \\
\hline $\mathrm{Tb}-157$ & $6.00 \mathrm{E}+02$ & & & & $1.90 \mathrm{E}-05$ & & \\
\hline Tb-158 & $1.00 \mathrm{E}+02$ & & & & $1.74 \mathrm{E}-05$ & & \\
\hline Ho- $166 \mathrm{~m}$ & $3.00 \mathrm{E}-01$ & & & & $3.25 \mathrm{E}-07$ & & \\
\hline Lu-176 & $3.00 \mathrm{E}-07$ & & . & & $3.38 \mathrm{E}-14$ & & \\
\hline Hf-178m & $8.00 \mathrm{E}-02$ & & & & $3.53 \mathrm{E}-09$ & & \\
\hline Hf- 182 & $3.00 \mathrm{E}-03$ & & & & $7.02 \mathrm{E}-13$ & & \\
\hline$W-181$ & $4.00 \mathrm{E}-03$ & & & & $4.69 \mathrm{E}-11$ & $2.17 \mathrm{E}-03$ & \\
\hline W-185 & $1.88 \mathrm{E}-13$ & & & & $7.98 \mathrm{E}-19$ & $4.65 \mathrm{E}-02$ & \\
\hline W-188 & $2.11 \mathrm{E}-18$ & & & & $3.90 \mathrm{E}-23$ & $2.94 \mathrm{E}-03$ & \\
\hline $\operatorname{Re}-187$ & $3.00 \mathrm{E}-04$ & & & & $3.35 \mathrm{E}-14$ & & \\
\hline Os-194 & $3.00 \mathrm{E}-13$ & & & & $1.58 \mathrm{E}-10$ & & \\
\hline Pt-193 & $4.00 \mathrm{E}-07$ & & & & $3.70 \mathrm{E}-03$ & & \\
\hline Tl-204 & & & & & $1.31 \mathrm{E}-02$ & & \\
\hline $\mathrm{Pb}-202$ & & & & & $1.73 \mathrm{E}-05$ & & \\
\hline $\mathrm{Pb}-205$ & . & & & & $2.31 \mathrm{E}-07$ & & \\
\hline $\mathrm{Pb}-210$ & & & & & $5.57 \mathrm{E}-10$ & & \\
\hline $\mathrm{Bi}-207$ & & & & & $8.34 \mathrm{E}-04$ & & \\
\hline Bi-210m & & & & & $1.21 \mathrm{E}-12$ & & \\
\hline
\end{tabular}


Table 4.3-2 Total Project Inventory of APT and TEF Waste

\begin{tabular}{|c|c|c|c|c|c|c|c|}
\hline & \multicolumn{5}{|c|}{ APT Waste } & \multicolumn{2}{|c|}{ TEF Waste } \\
\hline & Tungsten & Window & Steel & Aluminum & Lead & TPBAR & Baseplate \\
\hline Nuclide & Total $\mathrm{Ci}$ & Total $\mathrm{Ci}$ & Total $\mathrm{Ci}$ & Total Ci & Total $\mathrm{Ci}$ & Total Ci & Total Ci \\
\hline $\mathrm{H}-3$ & $2.40 \mathrm{E}+07$ & $8.00 \mathrm{E}+04$ & $8.00 \mathrm{E}+04$ & $2.36 \mathrm{E}+06$ & $2.70 \mathrm{E}+07$ & $1.92 \mathrm{E}+09$ & $1.81 \mathrm{E}-02$ \\
\hline $\mathrm{Be}-10$ & $1.60 \mathrm{E}-02$ & $8.00 \mathrm{E}-04$ & $8.00 \mathrm{E}-04$ & $5.68 \mathrm{E}-01$ & $2.79 \mathrm{E}+00$ & & \\
\hline $\mathrm{C}-14$ & $2.80 \mathrm{E}+00$ & $8.00 \mathrm{E}-01$ & $8.00 \mathrm{E}-01$ & $1.65 \mathrm{E}+02$ & $4.09 \mathrm{E}+03$ & $1.59 \mathrm{E}+03$ & $9.92 \mathrm{E}+01$ \\
\hline $\mathrm{Na}-22$ & $1.20 \mathrm{E}+04$ & $1.20 \mathrm{E}+03$ & $1.20 \mathrm{E}+03$ & $4.98 \mathrm{E}+05$ & $3.17 \mathrm{E}+05$ & & \\
\hline $\mathrm{Al}-26$ & $1.20 \mathrm{E}+00$ & $8.00 \mathrm{E}-02$ & $8.00 \mathrm{E}-02$ & $2.85 \mathrm{E}+02$ & $2.14 \mathrm{E}+02$ & & \\
\hline $\mathrm{Si}-32$ & $1.20 \mathrm{E}+02$ & $1.60 \mathrm{E}-03$ & $1.60 \mathrm{E}-03$ & $2.43 \mathrm{E}-05$ & $2.34 \mathrm{E}-02$ & & \\
\hline$S-35$ & $8.00 \mathrm{E}-14$ & 8.00E-09 & $8.00 \mathrm{E}-09$ & $7.50 \mathrm{E}-17$ & $5.36 \mathrm{E}-10$ & $6.48 \mathrm{E}+02$ & \\
\hline $\mathrm{Cl}-36$ & $3.00 \mathrm{E}+00$ & $3.20 \mathrm{E}-01$ & $3.20 \mathrm{E}-01$ & $3.22 \mathrm{E}-10$ & $5.56 \mathrm{E}+00$ & & \\
\hline Ar-39 & $1.20 \mathrm{E}+03$ & $1.20 \mathrm{E}+02$ & $1.20 \mathrm{E}+02$ & 8.12E-05 & $6.02 \mathrm{E}+02$ & $1.18 \mathrm{E}+03$ & \\
\hline Ar -42 & $1.60 \mathrm{E}+02$ & $1.20 \mathrm{E}-04$ & $1.20 \mathrm{E}-04$ & $2.41 \mathrm{E}-07$ & $6.25 \mathrm{E}+03$ & & \\
\hline $\mathrm{K}-40$ & $1.20 \mathrm{E}-03$ & $8.00 \mathrm{E}-05$ & $8.00 \mathrm{E}-05$ & $6.20 \mathrm{E}-09$ & $1.36 \mathrm{E}-02$ & & \\
\hline $\mathrm{Ca}-4 \mathrm{I}$ & $1.20 \mathrm{E}+01$ & $8.00 \mathrm{E}-01$ & $8.00 \mathrm{E}-01$ & $2.92 \mathrm{E}+00$ & $1.43 E+02$ & $7.61 \mathrm{E}+00$ & \\
\hline $\mathrm{Sc}-46$ & $1.20 \mathrm{E}-13$ & 8.00E-09 & $8.00 \mathrm{E}-09$ & $2.67 \mathrm{E}-10$ & $1.25 \mathrm{E}-08$ & $2.57 \mathrm{E}+02$ & \\
\hline $\mathrm{Ti}-44$ & $2.00 \mathrm{E}+03$ & $2.40 \mathrm{E}+02$ & $2.40 \mathrm{E}+02$ & $3.88 \mathrm{E}-10$ & & & \\
\hline$V-49$ & $2.00 \mathrm{E}+03$ & $1.20 \mathrm{E}+02$ & $1.20 \mathrm{E}+02$ & $7.37 \mathrm{E}+01$ & $1.26 \mathrm{E}+02$ & & \\
\hline $\mathrm{Mn}-53$ & $1.60 \mathrm{E}+00$ & $4.00 \mathrm{E}-02$ & $4.00 \mathrm{E}-02$ & $8.40 \mathrm{E}-10$ & $1.62 \mathrm{E}-01$ & & \\
\hline $\mathrm{Fe}-60$ & $3.20 \mathrm{E}-02$ & $8.00 \mathrm{E}-04$ & $8.00 \mathrm{E}-04$ & $2.46 \mathrm{E}-06$ & $3.48 \mathrm{E}-01$ & & \\
\hline Co-60 & $1.20 \mathrm{E}+06$ & $2.40 \mathrm{E}+03$ & $2.40 \mathrm{E}+03$ & $9.24 \mathrm{E}+02$ & $1.63 E+04$ & $5.46 \mathrm{E}+06$ & $1.08 E+06$ \\
\hline $\mathrm{Ni}-59$ & $4.00 \mathrm{E}+02$ & $2.40 \mathrm{E}+00$ & $2.40 \mathrm{E}+00$ & $3.67 \mathrm{E}+00$ & $9.01 \mathrm{E}-03$ & $4.25 \mathrm{E}+03$ & $4.45 \mathrm{E}+02$ \\
\hline $\mathrm{Ni}-63$ & $1.46 \mathrm{E}-02$ & $1.60 \mathrm{E}+02$ & $1.60 \mathrm{E}+02$ & $2.32 \mathrm{E}+03$ & $1.42 \mathrm{E}+04$ & $6.89 \mathrm{E}+05$ & $4.82 E+04$ \\
\hline $\mathrm{Ge}-68$ & $2.80 \mathrm{E}+00$ & $1.20 \mathrm{E}-01$ & $1.20 \mathrm{E}-01$ & & $1.03 \mathrm{E}+01$ & & \\
\hline Se-79 & $3.60 \mathrm{E}-01$ & $4.00 \mathrm{E}-06$ & $4.00 \mathrm{E}-06$ & & $4.29 \mathrm{E}+01$ & & \\
\hline $\mathrm{Kr}-81$ & $1.60 \mathrm{E}+00$ & $3.60 \mathrm{E}-02$ & $3.60 \mathrm{E}-02$ & & $6.25 \mathrm{E}+00$ & & \\
\hline $\mathrm{Kr}-85$ & $3.60 \mathrm{E}+02$ & $1.20 \mathrm{E}-03$ & $1.20 \mathrm{E}-03$ & & $3.14 \mathrm{E}+04$ & & \\
\hline $\mathrm{Rb}-87$ & $3.42 \mathrm{E}-14$ & $8.00 \mathrm{E}-13$ & $8.00 \mathrm{E}-13$ & & $2.77 \mathrm{E}-05$ & & \\
\hline Sr-90 & $2.40 \mathrm{E}+02$ & $8.00 \mathrm{E}-05$ & $8.00 \mathrm{E}-05$ & & $4.49 \mathrm{E}+04$ & & \\
\hline $\mathrm{Zr}-93$ & $1.20 \mathrm{E}-01$ & $1.20 \mathrm{E}-03$ & $1.20 \mathrm{E}-03$ & & $1.42 \mathrm{E}+00$ & $2.45 \mathrm{E}+01$ & \\
\hline $\mathrm{Nb}-93 \mathrm{~m}$ & $1.20 \mathrm{E}+05$ & $4.00 \mathrm{E}+02$ & $4.00 \mathrm{E}+02$ & & $4.49 \mathrm{E}+02$ & $1.13 E+00$ & \\
\hline Nb-94 & $4.00 \mathrm{E}+02$ & $8.00 \mathrm{E}-01$ & $8.00 \mathrm{E}-01$ & & $5.39 \mathrm{E}+01$ & $6.32 \mathrm{E}+01$ & $1.02 \mathrm{E}+00$ \\
\hline Mo-93 & $2.40 \mathrm{E}+02$ & $1.20 \mathrm{E}+00$ & $1.20 \mathrm{E}+00$ & & $3.69 \mathrm{E}+02$ & $1.21 \mathrm{E}+02$ & $3.03 E+00$ \\
\hline Tc-97 & $2.40 \mathrm{E}-01$ & $3.60 \mathrm{E}-09$ & $3.60 \mathrm{E}-09$ & & $4.38 \mathrm{E}-01$ & & \\
\hline Tc-98 & $3.20 \mathrm{E}-02$ & $8.00 \mathrm{E}-08$ & $8.00 \mathrm{E}-08$ & & $1.64 \mathrm{E}-01$ & & \\
\hline Tc-99 & $1.20 \mathrm{E}+01$ & $1.20 \mathrm{E}-02$ & $1.20 \mathrm{E}-02$ & & $1.52 \mathrm{E}+01$ & $3.16 \mathrm{E}+01$ & $2.33 \mathrm{E}-01$ \\
\hline Rh-101 & $3.60 \mathrm{E}+04$ & $8.00 \mathrm{E}-14$ & $8.00 \mathrm{E}-14$ & & $5.16 \mathrm{E}+04$ & & \\
\hline $\mathrm{Rh}-102 \mathrm{~m}$ & $8.00 \mathrm{E}-02$ & $4.00 \mathrm{E}-16$ & $4.00 \mathrm{E}-16$ & & $2.51 \mathrm{E}-01$ & & \\
\hline Rh-102 & $1.20 \mathrm{E}+04$ & $1.60 \mathrm{E}-12$ & $1.60 \mathrm{E}-12$ & & $9.30 \mathrm{E}+03$ & & \\
\hline Pd-107 & $1.60 \mathrm{E}-02$ & & & & $3.63 \mathrm{E}-01$ & & \\
\hline $\mathrm{Ag}-108 \mathrm{~m}$ & $2.80 \mathrm{E}+00$ & & & & $5.90 \mathrm{E}+00$ & & \\
\hline $\mathrm{Cd}-113 \mathrm{~m}$ & $1.20 \mathrm{E}+01$ & & & & $2.40 \mathrm{E}+01$ & & \\
\hline $\mathrm{Cd}-113$ & $8.00 \mathrm{E}-18$ & & & & & & \\
\hline In-115 & $3.20 \mathrm{E}-16$ & & & & & & \\
\hline
\end{tabular}




\begin{tabular}{|c|c|c|c|c|c|c|c|}
\hline & \multicolumn{5}{|c|}{ APT Waste } & \multicolumn{2}{|c|}{ TEF Waste } \\
\hline & Tungsten & Window & Steel & Aluminum & Lead & TPBAR & Baseplate \\
\hline Nuclide & Total Ci & Total Ci & Total $\mathrm{Ci}$ & Total Ci & Total $\mathrm{Ci}$ & Total $\mathrm{Ci}$ & Total $\mathrm{Ci}$ \\
\hline $\mathrm{Sn}-121 \mathrm{~m}$ & $1.60 \mathrm{E}-01$ & & & & $4.44 \mathrm{E}+02$ & $5.39 \mathrm{E}+01$ & \\
\hline Sn-126 & $1.60 \mathrm{E}-14$ & & & & $4.06 \mathrm{E}-05$ & & \\
\hline Te-123 & $1.60 \mathrm{E}-05$ & & & & $1.79 \mathrm{E}-08$ & & \\
\hline I-129 & $8.00 \mathrm{E}-05$ & & & & $1.59 \mathrm{E}-02$ & & \\
\hline $\mathrm{Xe}-127$ & & & & & $2.94 \mathrm{E}-25$ & & \\
\hline Cs-135 & $4.40 \mathrm{E}-04$ & & & & 1.32E-01 & & \\
\hline Cs- 137 & $1.60 \mathrm{E}-03$ & & & & $4.92 \mathrm{E}+00$ & & \\
\hline$B a-133$ & $1.20 \mathrm{E}+05$ & & & & $3.89 \mathrm{E}+04$ & $7.39 \mathrm{E}+01$ & \\
\hline La-137 & $1.20 \mathrm{E}+02$ & & & & $6.08 \mathrm{E}+00$ & & \\
\hline La- 138 & $3.20 \mathrm{E}-11$ & & & & $3.31 \mathrm{E}-06$ & & \\
\hline $\mathrm{Pm}-145$ & $1.60 \mathrm{E}+05$ & & & & $1.80 \mathrm{E}+04$ & & \\
\hline Sm-146 & $3.20 \mathrm{E}-02$ & & & & $1.45 \mathrm{E}-02$ & & \\
\hline $\mathrm{Sm}-147$ & $2.80 \mathrm{E}-05$ & & & & $7.92 \mathrm{E}-06$ & & \\
\hline $\mathrm{Sm}-151$ & $1.60 \mathrm{E}+02$ & & & & $2.28 \mathrm{E}+03$ & . & \\
\hline Eu-150 & $4.00 \mathrm{E}+03$ & & & & $3.48 \mathrm{E}+03$ & & \\
\hline Eu-152 & $1.60 \mathrm{E}+04$ & & & & $3.08 \mathrm{E}+03$ & & \\
\hline Eu-154 & $2.40 \mathrm{E}+03$ & & & & $1.18 \mathrm{E}+04$ & & \\
\hline Gd-148 & $3.60 \mathrm{E}+04$ & & & & $1.85 \mathrm{E}+04$ & & \\
\hline Gd-152 & $8.00 \mathrm{E}-13$ & & & & $2.41 \mathrm{E}-08$ & & \\
\hline $\mathrm{Tb}-157$ & $2.40 \mathrm{E}+04$ & & & & $9.10 \mathrm{E}+03$ & & \\
\hline Tb-158 & $4.00 \mathrm{E}+03$ & & & & $8.35 E+03$ & & \\
\hline Ho- $166 \mathrm{~m}$ & $1.20 \mathrm{E}+01$ & & & & $1.56 \mathrm{E}+02$ & & \\
\hline Lu-176 & $1.20 \mathrm{E}-05$ & & & & $1.62 \mathrm{E}-05$ & & \\
\hline Hf $-178 m$ & $3.20 \mathrm{E}+00$ & & & & $1.70 \mathrm{E}+00$ & & \\
\hline Hf- 182 & $1.20 \mathrm{E}-01$ & & & & 3.37E-04 & & \\
\hline W-181 & $1.60 \mathrm{E}-01$ & & & & $2.25 \mathrm{E}-02$ & $3.65 \mathrm{E}+02$ & \\
\hline W-185 & $7.52 \mathrm{E}-12$ & & & & $3.83 \mathrm{E}-10$ & $7.81 \mathrm{E}+03$ & \\
\hline W-188 & $8.44 \mathrm{E}-17$ & & & & $1.87 \mathrm{E}-14$ & $4.94 \mathrm{E}+02$ & \\
\hline $\operatorname{Re}-187$ & $1.20 \mathrm{E}-02$ & & & & $1.61 \mathrm{E}-05$ & & \\
\hline Os-194 & $1.20 \mathrm{E}-11$ & & & & $7.57 \mathrm{E}-02$ & & \\
\hline Pt-193 & $1.60 \mathrm{E}-05$ & & & & $1.78 \mathrm{E}+06$ & & \\
\hline TI-204 & & & & & $6.28 \mathrm{E}+06$ & & \\
\hline $\mathrm{Pb}-202$ & & & & & $8.32 \mathrm{E}+03$ & & \\
\hline $\mathrm{Pb}-205$ & & & & & $1.11 \mathrm{E}+02$ & & \\
\hline $\mathrm{Pb}-210$ & & & & & $2.68 \mathrm{E}-01$ & & \\
\hline $\mathrm{Bi}-207$ & & & & & $4.00 \mathrm{E}+05$ & & \\
\hline $\mathrm{Bi}-210 \mathrm{~m}$ & & & & & $5.82 \mathrm{E}-04$ & & \\
\hline
\end{tabular}




\subsection{Groundwater Pathway Analysis}

After the screening and scoping steps for the ground water pathway reduced the set of radionuclides requiring further consideration, the remaining radionuclides were analyzed using numerical models. The vadose zone numerical models simulated the fate and transport of radionuclides from the waste through the vadose zone to the water table. The aquifer numerical models simulated the fate and transport of radionuclides from the water table through the aquifer to a well 400 feet $(122-\mathrm{m})$ from the vault $(100-\mathrm{m}$ from the facility).

The vadose zone model simulated the corrosion of the waste container and the wasteform. The contaminant movement was calculated from the waste to the water table, producing an output of contaminant flux to the water table. This flux became the source input to the aquifer model. Modeling results are presented below in separate sections for the vadose zone and the aquifer.

The numerical models require inputs for the following categories of information:

Source terms

Geometry

Material properties

Boundary and initial conditions.

Each of these categories is described below in the sections on modeling inputs.

The numerical models were based on the PORFLOW computer program, version $4^{17}$, and the FACT ${ }^{18}$ computer program. The PORFLOW program was used to simulate flow and transport through the vadose zone. The FACT program was used to simulate flow through the aquifer. The PORFLOW program was used to simulate transport through the aquifer. Descriptions of these programs and the interfaces are described in the LLWF PA ${ }^{3}$.

\subsubsection{Vadose Zone Modeling}

The vadose zone model was based on the original E-Area PA $^{3}$ model with appropriate changes to accommodate different radionuclides produced by the APT process and different release mechanisms. For consistency with the revised E-Area PA, the latest version of PORFLOW was employed.

\subsubsection{Sources}

Sources consist of radionuclides present in wasteforms enclosed in stainless steel waste containers. The list of radionuclides is those that remained after the scoping analysis was completed. A list of the radionuclides is presented in the section on material properties, while this section describes the release mechanisms.

The vadose zone model includes four stages of source releases, as shown in Figure 4.4.1. There is no source release for the initial stage when the waste container is intact. The wasteform corrodes during this stage, hence radionuclides become available for release inside the waste container. The second stage represents an accelerated release rate. The waste container has breached and radionuclides from previous corrosion and ongoing corrosion are released simultaneously. During the third stage, only radionuclides from ongoing corrosion are released. The final stage is when all radionuclides have been released. These stages ignore any diffusion through the waste container. Ignoring diffusion results in a higher, but delayed rate of contaminant release that may not be conservative for short-lived radionuclides.

The assumed release conditions are as follows:

- Corrosion of the wasteform makes radionuclides available for release

- Release does not occur until the waste container is breached

- The waste container is breached when it corrodes to one-half its original thickness

- After the waste container is breached, radionuclides generated by new corrosion of the wasteform are released immediately

- Before the waste container is breached, radionuclides generated by new corrosion of the wasteform are stored inside the waste container. These radionuclides are released after the breach. The duration of their release is equal to the duration of their generation. During their release, the waste container still partially exists.

- The corrosion rate for the wasteform is constant and starts from time zero

- The corrosion rate for the waste container is constant and starts from time zero 


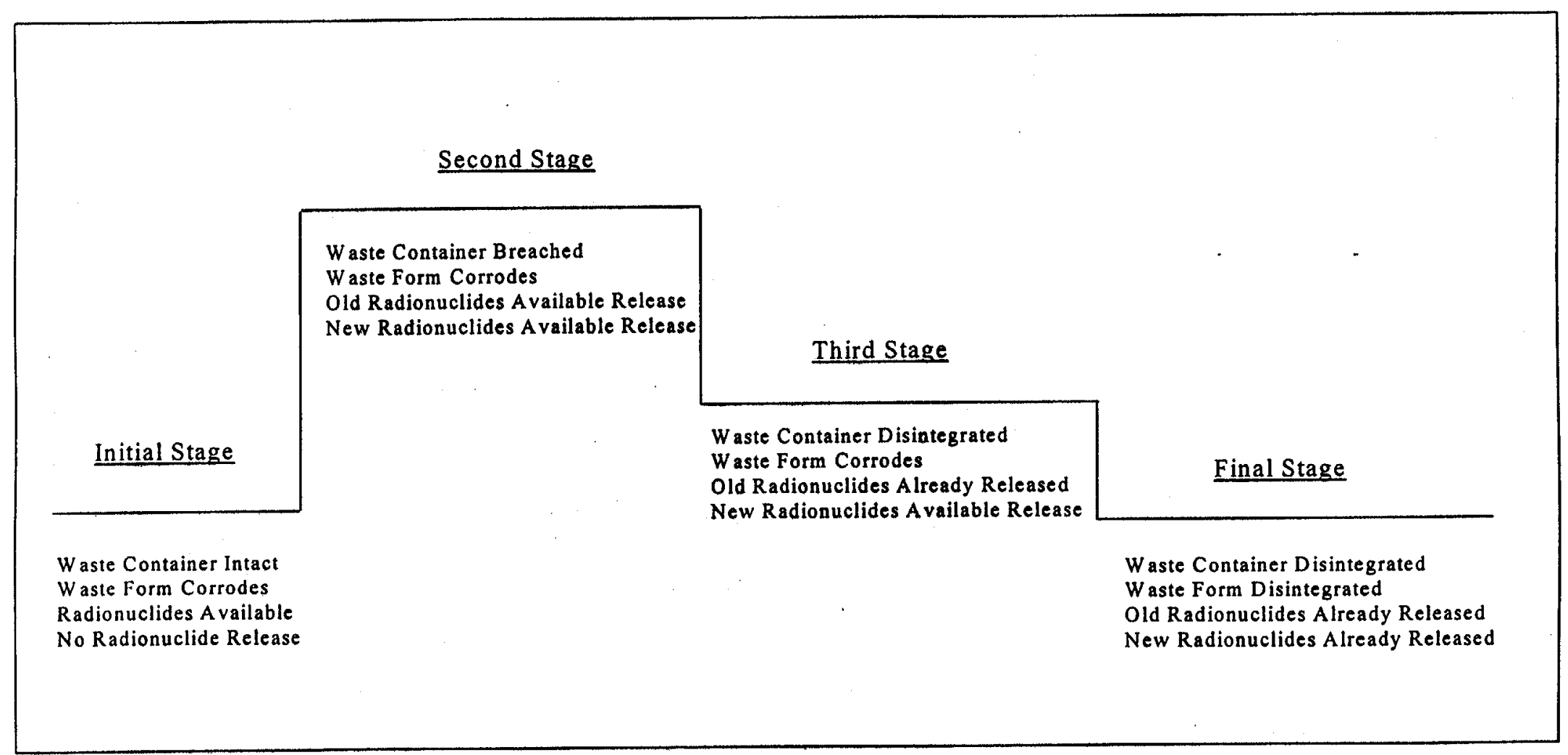

Figure 4.4.1 Stages of Source Release 


\subsection{Waste Container Corrosion}

Chandler ${ }^{14}$ studied the rate of corrosion of the steel waste container. The corrosion rate derived from the study was $10 \mu \mathrm{m} / \mathrm{yr}$. The waste container is one-half inch thick. We assumed the container would not allow any release until it had corroded to one-half of its original thickness. Thus, radionuclide release from the container would not commence for 635 years.

\subsection{Wasteform Corrosion}

The corrosion rate of the wasteform is a function of the type of material. Chandler's study ${ }^{14}$ considered six material types as follows:
1. Carbon steel
2. Stainless Steel
3. Tungsten
4. Aluminum
5. Lead
6. Inconel 718

APT waste includes all these types of material. TEF Waste is stainless steel.

Based on Chandler's results ${ }^{14}$, we assumed that the wasteforms could be represented by a single wasteform one centimeter thick, with a corrosion rate of $2.54 \mu \mathrm{m} / \mathrm{yr}$. Thus, the fraction of the wasteform corroded each year is 2.54E-4. The wasteform corrodes at this constant rate for 3,937 years.

\subsection{Waste Release Rates}

The waste release rates are a combined function of the waste container breaching and the wasteform corroding. The various release rates are shown in Table 4.4-1. Decay is not considered in these release rates, but it is considered in the model.

\begin{tabular}{|c|c|c|c|c|l|}
\hline \multicolumn{7}{|c|}{ Table 4.4-1. Fractional Release Rates Neglecting Decay } \\
\hline Start & End & Corrosion Rate & Release Rate & & \\
\hline (year) & (year) & Per Year) & Per year) & (year) & \multicolumn{1}{|c|}{ Comments } \\
\hline 1 & 635 & $2.54 \mathrm{E}-04$ & 0 & 635 & $\begin{array}{l}\text { Container intact } \\
\text { Zero release }\end{array}$ \\
\hline 636 & 1270 & $2.54 \mathrm{E}-04$ & $5.08 \mathrm{E}-04$ & 635 & $\begin{array}{l}\text { Container breached } \\
\text { Release from old and new radionuclides }\end{array}$ \\
\hline 1271 & 3937 & $2.54 \mathrm{E}-04$ & $2.54 \mathrm{E}-04$ & 2667 & $\begin{array}{l}\text { Container disintegrated } \\
\text { All old radionuclides released } \\
\text { release only from new radionuclides }\end{array}$ \\
\hline post 3937 & & 0 & 0 & & $\begin{array}{l}\text { Wasteform disintegrated } \\
\text { Zero release }\end{array}$ \\
\hline
\end{tabular}

\subsubsection{Geometry}

The geometry for the vadose zone model is depicted in Figure 4.4.2. Taking advantage of symmetry, a crosssection representing only one-half the width of the Intermediate Level Vault was modeled. This cross-section represents the center of a vault that is $58-\mathrm{m}$ long, i.e., perpendicular to the plane of the paper.

The total width for both vault halves is $14.8 \mathrm{~m}$. The vaults stand $8.63-\mathrm{m}$ high above a concrete base that is $0.76-\mathrm{m}$ thick. The waste is $7.9-\mathrm{m}$ high, while the concrete roof is $0.71-\mathrm{m}$ high. A $0.40-\mathrm{m}$ thick clay cap covers the roof. A sand layer surrounds the clay and the concrete walls and base. The sand layer is $0.90-\mathrm{m}$ thick below the base, 0.50 $\mathrm{m}$ thick above the roof, and $3-\mathrm{m}$ thick horizontally beyond the wall.

The top of the sand is covered by a $1.81-\mathrm{m}$ thick backfill layer that extends to the ground surface. The bottom of the sand lays $8-\mathrm{m}$ above the water table that represents the bottom of the vadose zone. Backfill extends $7.6-\mathrm{m}$ from the outer edge of the sand to the side of the model domain.

The mesh generated for the model is depicted in Figure 4.4.3. The thick lines in the figure represent the boundaries for the waste, the vault, and the barrier. The mesh refinement at the material interfaces and for the relatively thin clay and concrete materials are shown as narrowly spaced lines. 


\subsubsection{Material Properties}

Each soil or sediment layer is a separate material, as are the concrete and the waste. The waste is treated as concrete, because it is grouted. No differentiation is made between backfill material and native soil. Contaminant properties are presented as a subsection, because some properties are functions of both the contaminant and the in situ material, e.g., the distribution coefficient.

Each material is considered homogeneous and isotropic, hence spatial variation is not allowed for any property within the material. However, three stages of vault integrity are used. The initial stage represents an intact vault with typical concrete properties. The second stage represents a cracked vault with higher hydraulic conductivities and higher flows through some of the concrete and the waste, but with the same infiltration rate. The final stage represents a failed vault with many materials changing accompanied by an increased infiltration rate. The stages and their times are shown in Table 4.4-2.

Table 4.4-2. Vault Integrity
\begin{tabular}{|c|c|c|c|c|}
\hline Start & End & Vault & Duration & Infiltration Rate \\
\hline (year) & (year) & Condition & (years) & (cm/yr.) \\
\hline 0 & 575 & Intact & 575 & 4 \\
\hline 576 & 1050 & Cracked & 475 & 4 \\
\hline Post 1050 & & Failed & & 40 \\
\hline
\end{tabular}

For the flow model and the transport model, each material requires the particle density and the porosity. For the flow model, hydraulic properties consisting of the matrix compressibility and the hydraulic conductivities in the principal axis directions are required. For the unsaturated flow aspects, parameters to satisfy the van Genuchten curves are needed, i.e., the N, Alpha and residual saturation (see Table 4.4.3). For the transport model, the longitudinal dispersivity and the transverse dispersivity are required.

The model input values for each material type are presented in Table 4.4-3. Table 4.4-3 shows the following changes for the cracked vault:

1. the concrete roof behaves like clay 2 . The waste behaves like backfill 3 . the concrete walls behave like sand

Each material is replaced by the material surrounding it. The waste is replaced by the concrete walls, which have been replaced by the sand; consequently, the waste is actually replaced by sand.

Table 4.4-3 shows the following changes for the failed vault:

1. the concrete roof behaves like backfill 2. the waste behaves like backfill 3 . the clay behaves like backfill

4. the concrete floor behaves like sand 5 . the concrete walls behave like sand

The concrete and the clay disappear. The roof, the clay and the waste are replaced by backfill, because insufficient backfill lies over the vault to completely replace the failed materials. Meanwhile, the concrete floor and walls are replaced by the adjacent sand.

Freeze and Cherry ${ }^{16}$ provided expected ranges of values for materials. Those ranges are shown in Table 4.4-4.

\begin{tabular}{|l|l|l|l|l|}
\hline & \multicolumn{3}{|c|}{ Table 4.4-4. Selected Input Parameter Ranges from the Literature } \\
\hline Material Type & $\left(\mathrm{m}^{2} / \mathrm{N}\right)$ & \multicolumn{2}{c|}{ Saturated Hydraulic Conductivity } \\
\hline Clay & $1 \mathrm{E}-6$ to $1 \mathrm{E}-8$ & $1 \mathrm{E}-10$ to $1 \mathrm{E}-12$ & NA & (cm/yr) \\
\hline Sand & $1 \mathrm{E}-7$ to $1 \mathrm{E}-9$ & $1 \mathrm{E}-11$ to $1 \mathrm{E}-13$ & NA & NA \\
\hline $\begin{array}{l}\text { Unweathered } \\
\text { Marine clay }\end{array}$ & & & $5 \mathrm{E}-11$ to $1 \mathrm{E}-7$ & $1.6 \mathrm{E}-3$ to $3.2 \mathrm{E} 0$ \\
\hline Glacial till & & & & \\
\hline Silt, loess & & & $1 \mathrm{E}-10$ to $1 \mathrm{E}-4$ & $3.2 \mathrm{E}-3$ to $3.2 \mathrm{E} 3$ \\
\hline Silty sand & & & SE-6 to $1 \mathrm{E}-1$ & $3.2 \mathrm{E} 0$ to $3.2 \mathrm{E} 4$ \\
\hline Clean sand & & & $5 \mathrm{E}-4$ to $1 \mathrm{E} 0$ & $1.6 \mathrm{E} 2$ to $3.2 \mathrm{E} 6$ \\
\hline
\end{tabular}




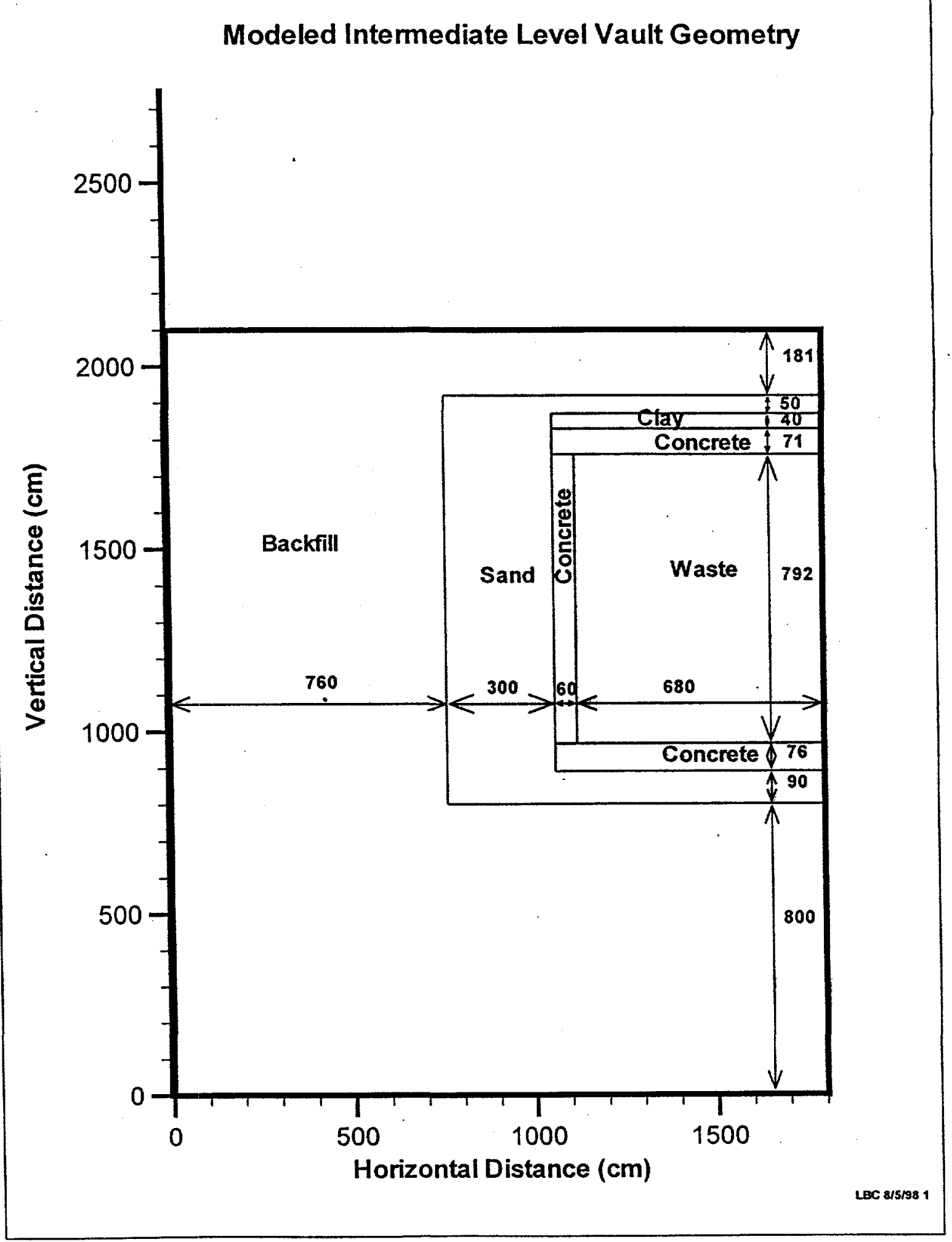

Figure 4.4.2. Vault Geometry 


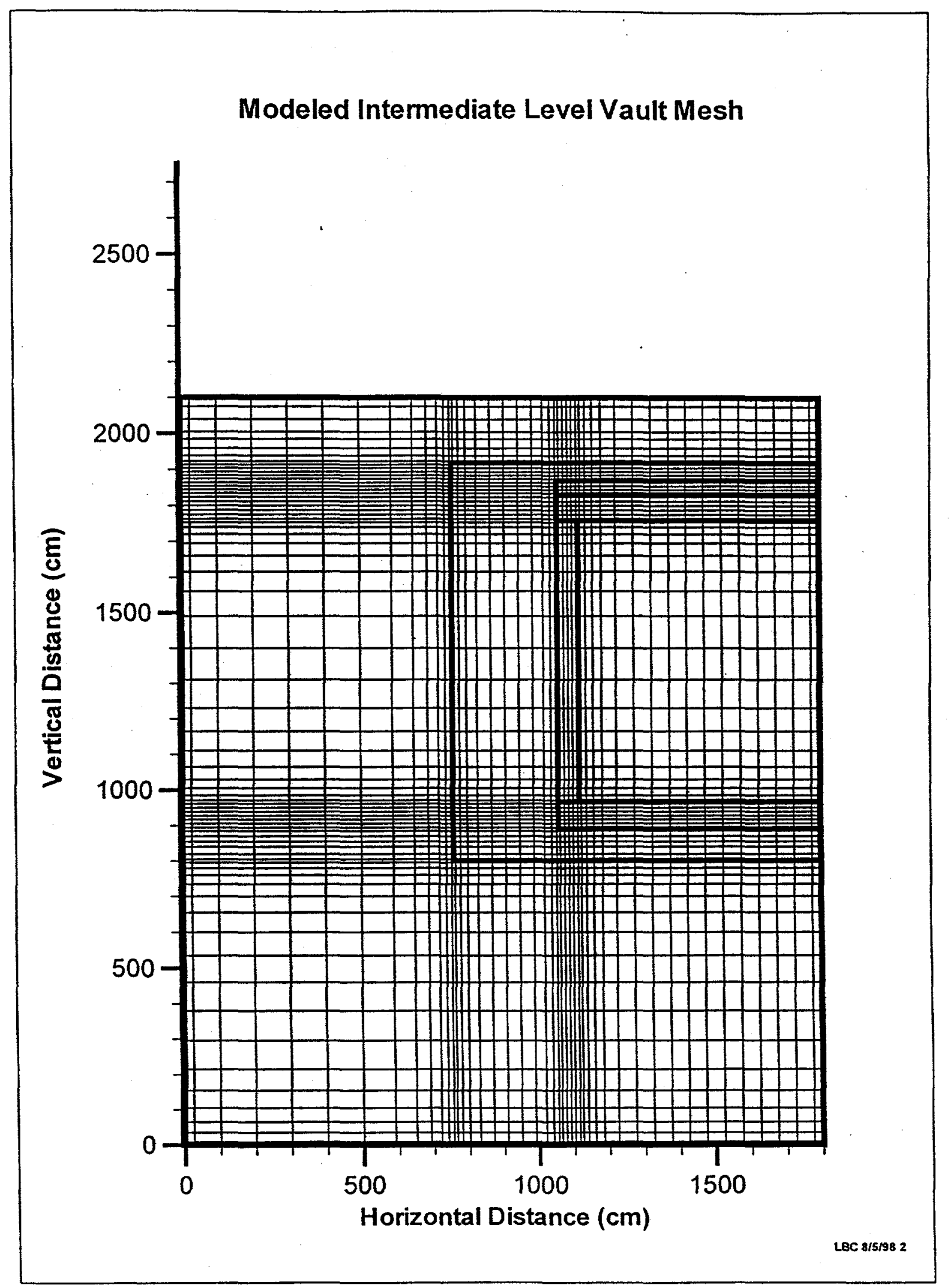

Figure 4.4.3. Vault Mesh 
Table 4.4-3a. Properties for Intact Vault

\begin{tabular}{|c|c|c|c|c|c|c|c|c|c|c|}
\hline & \multicolumn{2}{|c|}{ All Models } & \multicolumn{2}{|l|}{ Flow Model Only } & \multicolumn{3}{|c|}{ Unsaturated Part of Flow } & \multicolumn{3}{|c|}{ Transport Model Only } \\
\hline Description & $\begin{array}{l}\text { Particle } \\
\text { Density } \\
\text { (g/cc) }\end{array}$ & Porosity & $\begin{array}{l}\text { Compressibility } \\
\left(\mathrm{cm}^{2} / \mathrm{N}\right)\end{array}$ & $\begin{array}{l}\text { Hydraulic } \\
\text { Conductivity } \\
\text { (cm/yr) }\end{array}$ & $N$ & $\begin{array}{l}\text { Alpha } \\
(1 / \mathrm{cm})\end{array}$ & $\begin{array}{l}\text { Residual } \\
\text { Saturation }\end{array}$ & $\begin{array}{l}\text { Longitudinal } \\
\text { Dispersivity } \\
\text { (cm) }\end{array}$ & $\begin{array}{l}\text { Transverse } \\
\text { Dispersivity } \\
(\mathrm{cm})\end{array}$ & \\
\hline Backfill & 1.6 & .439 & $1 \mathrm{E}-3$ & $3.154 \mathrm{E} 2$ & 1.70 & .075 & 20 & 1 & & 2 \\
\hline Sand & 2.6 & .375 & 1E-7 & $3.154 \mathrm{E} 4$ & 2.50 & .055 & .20 & 1 & & 2 \\
\hline Concrete Roof & 2.6 & .150 & $1 \mathrm{E}-7$ & $3.154 \mathrm{E}-3$ & 3.43 & $5.98 \mathrm{E}-4$ & .98 & & & 2 \\
\hline Waste & 1.7 & .500 & $1 \mathrm{E}-7$ & $3.154 \mathrm{E}-3$ & $\overline{3.43}$ & $5.98 \mathrm{E}-4$ & .98 & & & 2 \\
\hline Clay & 2.6 & .386 & $6 \mathrm{E}-4$ & $3.154 \mathrm{E} 0$ & $1.51^{\circ}$ & $1.75 \mathrm{E}-3$ & .88 & & & 2 \\
\hline Concrete Floor & 2.6 & .150 & $1 \mathrm{E}-7$ & $3.154 \mathrm{E}-3$ & 3.43 & $5.98 \mathrm{E}-4$ & .98 & & & 2 \\
\hline Concrete Walls & 2.6 & .150 & 1E-7 & $3.154 \mathrm{E}-3$ & 3.43 & $5.98 \mathrm{E}-4$ & .98 & & & 2 \\
\hline
\end{tabular}

Table 4.4-3b. Properties Changed for Cracked Vault

\begin{tabular}{|c|c|c|c|c|c|c|c|c|c|}
\hline & \multicolumn{2}{|c|}{ All Models } & \multicolumn{2}{|l|}{ Flow Model Only } & \multicolumn{3}{|c|}{ Unsaturated Part of Flow } & \multicolumn{2}{|c|}{ Transport Model Only } \\
\hline Description & $\begin{array}{l}\text { Particle } \\
\text { Density } \\
\text { (g/cc) }\end{array}$ & Porosity & $\begin{array}{l}\text { Compressibility } \\
\left(\mathrm{cm}^{2} / \mathrm{N}\right)\end{array}$ & $\begin{array}{l}\text { Hydraulic } \\
\text { Conductivity } \\
(\mathrm{cm} / \mathrm{yr})\end{array}$ & $\mathrm{N}$ & $\begin{array}{l}\text { Alpha } \\
(1 / \mathrm{cm})\end{array}$ & $\begin{array}{l}\text { Residual } \\
\text { Saturation }\end{array}$ & $\begin{array}{l}\text { Longitudinal } \\
\text { Dispersivity } \\
\text { (cm) }\end{array}$ & $\begin{array}{l}\text { Transverse } \\
\text { Dispersivity } \\
\text { (cm) }\end{array}$ \\
\hline Backfill & & & & & & & & & \\
\hline Sand & & & & & & & & & \\
\hline Concrete Roof & & & & $3.154 \mathrm{E} 0$ & 1.51 & $1.75 \mathrm{E}-3$ & .88 & & \\
\hline Waste & & & & $3.154 \mathrm{E} 2$ & 1.70 & .075 & .20 & & \\
\hline Clay & & & & & & & & & \\
\hline Concrete Floor & & & & & & & & & \\
\hline Concrete Walls & & & & $3.154 \mathrm{E} 4$ & 2.50 & .055 & .20 & & \\
\hline
\end{tabular}

Table 4.4-3c. Properties Changed for Failed Vault

\begin{tabular}{|c|c|c|c|c|c|c|c|c|c|}
\hline & \multicolumn{2}{|c|}{ All Models } & \multicolumn{2}{|l|}{ Flow Model Only } & \multicolumn{3}{|c|}{ Unsaturated Part of Flow } & \multicolumn{2}{|c|}{ Transport Model Only } \\
\hline Description & $\begin{array}{l}\text { Particle } \\
\text { Density } \\
(\mathrm{g} / \mathrm{cc})\end{array}$ & Porosity & $\begin{array}{l}\text { Compressibility } \\
\left(\mathrm{cm}^{2} / \mathrm{N}\right)\end{array}$ & $\begin{array}{l}\text { Hydraulic } \\
\text { Conductivity } \\
(\mathrm{cm} / \mathrm{yr})\end{array}$ & $\mathrm{N}$ & $\begin{array}{l}\text { Alpha } \\
(1 / \mathrm{cm})\end{array}$ & $\begin{array}{l}\text { Residual } \\
\text { Saturation }\end{array}$ & $\begin{array}{l}\text { Longitudinal } \\
\text { Dispersivity } \\
\text { (cm) }\end{array}$ & $\begin{array}{l}\text { Transverse } \\
\text { Dispersivity } \\
\text { (cm) }\end{array}$ \\
\hline Backfill & & & & & & & & & \\
\hline Sand & & & & & & & & & \\
\hline Concrete Roof & & & & $3.154 \mathrm{E} 2$ & 1.7 & .075 & .20 & & \\
\hline Waste & & & & $3.154 \mathrm{E} 2$ & 1.7 & .075 & .20 & & \\
\hline Claly & & & $11:-7$ & $3.1541: 2$ & 1.7 & .075 & .20 & & \\
\hline Concrete Floor & & & & $3.154 \mathrm{E} 4$ & 2.5 & .055 & .20 & & \\
\hline Concrete Walls & & & & $3.154 \mathrm{E} 4$ & 2.5 & .055 & .20 & & \\
\hline
\end{tabular}




\subsubsection{Contaminant Properties}

For the transport model, the distribution coefficient $\left(k_{d}\right)$, the molecular diffusivity, and the half-life of the contaminant are required. Table 4.4-5 contains the contaminant properties specified by material type. The waste was assigned the same values as the concrete.

\begin{tabular}{|l|c|c|c|c|}
\hline \multirow{4}{*}{ Radionuclide } & \multicolumn{4}{|c|}{ Table 4.4-5. Distribution Coefficients } \\
\cline { 2 - 5 } & Concrete & Soil & Clay & Half-life \\
\cline { 2 - 5 } & $(\mathrm{ml} / \mathrm{g})$ & $(\mathrm{ml} / \mathrm{g})$ & $(\mathrm{m} / \mathrm{g})$ & (years) \\
\hline Al-26 & 100.0 & 1500.0 & 1500.0 & $7.20 \mathrm{E}+05$ \\
\hline $\mathrm{Be}-10$ & $1 . \mathrm{E}-03$ & 250.0 & 1300.0 & $1.60 \mathrm{E}+06$ \\
\hline $\mathrm{C}-14$ & 5000.0 & 2.0 & 1.0 & $5.73 \mathrm{E}+03$ \\
\hline $\mathrm{Ca}-41$ & 1.0 & 5.0 & 50.0 & $1.03 \mathrm{E}+05$ \\
\hline $\mathrm{Cl}-36$ & 20.0 & 1.7 & 1.7 & $3.01 \mathrm{E}+05$ \\
\hline Fe-60 & 100.0 & 220.0 & 165.0 & $3.00 \mathrm{E}+05$ \\
\hline $\mathrm{Hf}-182$ & 5000.0 & 450.0 & 2400.0 & $9.00 \mathrm{E}+06$ \\
\hline $\mathrm{Ho}-166 \mathrm{~m}$ & 5000.0 & 250.0 & 1300.0 & $1.20 \mathrm{E}+03$ \\
\hline $\mathrm{I}-129$ & 2.0 & 1.0 & 1.0 & $1.57 \mathrm{E}+07$ \\
\hline $\mathrm{K}-40$ & $1 . \mathrm{E}-03$ & 15.0 & 75.0 & $1.28 \mathrm{E}+09$ \\
\hline $\mathrm{La}-137$ & 1200.0 & 1200.0 & 1200.0 & $6.00 \mathrm{E}+04$ \\
\hline $\mathrm{Mn}-53$ & 100.0 & 50.0 & 180.0 & $3.70 \mathrm{E}+06$ \\
\hline $\mathrm{Mo}-93$ & 0.1 & 10.0 & 90.0 & $3.50 \mathrm{E}+03$ \\
\hline $\mathrm{Nb}-94$ & 500.0 & 160.0 & 900.0 & $2.03 \mathrm{E}+04$ \\
\hline $\mathrm{Ni}-59$ & 100.0 & 400.0 & 55.0 & $7.50 \mathrm{E}+04$ \\
\hline $\mathrm{Pb}-202$ & 500.0 & 270.0 & 270.0 & $3.00 \mathrm{E}+05$ \\
\hline $\mathrm{Pb}-205$ & 500.0 & 270.0 & 270.0 & $1.51 \mathrm{E}+07$ \\
\hline $\mathrm{Se}-79$ & 0.1 & 150.0 & 740.0 & $6.50 \mathrm{E}+04$ \\
\hline $\mathrm{Si}-32$ & 3.5 & 35.0 & 180.0 & $3.30 \mathrm{E}+02$ \\
\hline $\mathrm{Sm}-146$ & 5000.0 & 245.0 & 1300.0 & $7.00 \mathrm{E}+07$ \\
\hline $\mathrm{Tb}-158$ & 240.0 & 240.0 & 240.0 & $1.20 \mathrm{E}+03$ \\
\hline $\mathrm{Tc}-99$ & 1000.0 & 0.1 & 1.0 & $2.13 \mathrm{E}+05$ \\
\hline $\mathrm{Zr}-93$ & 5000.0 & 600.0 & 3300.0 & $1.53 \mathrm{E}+06$ \\
\hline
\end{tabular}

Molecular diffusivity values for all radionuclides were assigned as follows:

\begin{tabular}{|l|c|}
\hline Material Type & Molecular Diffusivity $\left(\mathrm{cm}^{2} / \mathbf{y r}\right)$ \\
\hline Backfill & 158 \\
\hline Sand & 158 \\
\hline Concrete Roof & 0.315 \\
\hline Waste & 0.158 \\
\hline Clay & 47 \\
\hline Concrete Floor & 0.315 \\
\hline Concrete Wall & 0.315 \\
\hline
\end{tabular}

When the vault cracks and fails, the distribution coefficients are not changed, because the distribution coefficient primarily represent a chemical property, while the hydraulic conductivity and the unsaturated values primarily represent physical properties. Although the concrete degrades with cracks and openings being filled with sand or backfill, the predominant unsaturated flow is expected to be through the concrete where adsorption and desorption 
will continue at the same rate as in the intact case. The waste material that initially contains the radionuclides is also expected to retain its original distribution properties. If more flow actually moves through the infill material than through the waste material, then the release of contaminants would be reduced.

\subsubsection{Boundary and Initial Conditions}

Boundary conditions are prescribed around the perimeter of the modeling domain. For the flow model, they normally are either pressure heads $(\mathrm{cm})$ or velocities $(\mathrm{cm} / \mathrm{yr})$. For the transport model, they either normally are concentrations $(\mathrm{Ci} / \mathrm{cc})$ or mass flux $(\mathrm{Ci} / \mathrm{yr})$. The boundary conditions for each model are shown in Table 4.4-6.

\begin{tabular}{|c|c|c|c|}
\hline Model & Side & Condition & Comments \\
\hline \multirow[t]{4}{*}{ Flow } & $\begin{array}{l}\text { Left hand - } \\
X \text { minus }\end{array}$ & Zero velocity & $\begin{array}{l}\text { Assumed far enough away from vault that infiltration has } \\
\text { returned to normal, vertically downward mode }\end{array}$ \\
\hline & $\begin{array}{l}\text { Right hand - } \\
\mathrm{X} \text { plus }\end{array}$ & Zero velocity & $\begin{array}{l}\text { Symmetry with right-hand side of vault that is not } \\
\text { modeled }\end{array}$ \\
\hline & $\begin{array}{l}\text { Bottom - } \\
\text { Y minus }\end{array}$ & Zero pressure & Water table \\
\hline & $\begin{array}{l}\text { Top - } \\
\text { Y plus }\end{array}$ & $\begin{array}{l}\text { Intact vault }-4 \mathrm{~cm} / \mathrm{yr} \\
\text { Cracked vault }-4 \mathrm{~cm} / \mathrm{yr} \\
\text { Failed vault }-40 \mathrm{~cm} / \mathrm{yr}\end{array}$ & $\begin{array}{l}\text { Recharge rates through cap that ultimately reach water } \\
\text { table } \\
\text { Assumed cap failure }\end{array}$ \\
\hline \multirow[t]{4}{*}{ Transport } & $\begin{array}{l}\text { Left hand - } \\
X \text { minus }\end{array}$ & Zero mass flux & Assumed far enough away that has no impact \\
\hline & $\begin{array}{l}\text { Right hand - } \\
\mathrm{X} \text { plus }\end{array}$ & Zero mass flux & $\begin{array}{l}\text { Symmetry with right-hand side of vault that is not } \\
\text { modeled }\end{array}$ \\
\hline & $\begin{array}{l}\text { Bottom - } \\
\text { Y minus }\end{array}$ & Zero concentration & $\begin{array}{l}\text { Causes contaminant to instantly be swept away providing } \\
\text { maximum mass flux at water table }\end{array}$ \\
\hline & $\begin{array}{l}\text { Top- } \\
\text { Y plus }\end{array}$ & Zero concentration & Zero concentration assumed in atmosphere \\
\hline
\end{tabular}

Initial conditions are the starting estimates for solving the equations. The flow model is solved until steady state conditions; hence, the starting estimates do not affect the results. For the transport model, the subsurface is assumed to be free of any contamination, hence the concentrations are set to zero everywhere.

\subsubsection{Modeling Results}

The flow model analyses culminated in generating steady-state flow fields through the vault, the waste and the surrounding vadose zone for three scenarios, namely for the intact, cracked and failed vault cases. The flow results provided the advective driver to transport the contaminants from the waste to the water table. The transport model analyses culminated in generating mass fluxes to the water table for each radionuclide that remained after the screening and scoping analyses. The results for each model are discussed below.

\subsection{Flow Model}

The flow model for each vault scenario was executed until steady state conditions were achieved. Pairs of figures are presented showing the modeling results for the intact vault scenario, the cracked vault scenario, and the failed vault scenario, respectively. 


\subsection{Intact Vault Scenario}

Figures 4.4.4 and 4.4.5 show velocity field results from the intact vault scenario. The former figure shows the direction of the flows only, while the latter figure shows the actual magnitudes. The latter figure also shows streamlines and time markers.

The velocity plots show that meteoric water infiltrating down through the surface barrier primarily skirts around the vault. The clay and sand layers over the concrete roof divert the infiltrating water, which moves horizontally to the upper left corner of the vault roof. The water then "spills" into the sand surrounding the vault, where it continues traveling down with some water being pushed away from the vault. At the base of the vault, the water turns the comer and moves horizontally beneath the base of the vault through the sand layer.

The vertical sand layer carries the infiltration water from above the vault roof and attracts a small amount of moisture from the adjacent backfill. At the far-left edge of the model, the flow is downward which demonstrates little if any impact from the presence of the vault.

Minimal flow occurs through the vault and waste. That flow is essentially all vertically downward. In the native soil beneath the vault, the flow is reduced near the center of the vault.

The streamlines and time markers show the Darcy travel times. The distance between each pair of time markers represents the length of time required for a particle of water to travel between the markers. The thick solid streamline through the vault reflects closely spaced time markers and very slow travel velocities. The Darcy times are "apparent" times that assume that flow occurs through the entire soil matrix. However, because water can only travel through the soil pores, it must travel faster. For a pore porosity of 0.25 , the speed is increased by a factor of four, and the time is decreased by a like factor.

At the far-left edge of the model where the vault has minimal influence, the Darcy travel time is 509 years. The sixth streamline from the left-hand side represents the shortest travel time of 177 years. This streamline must accommodate the increased flow generated from above the vault roof. The farthest right streamline beneath the center of the vault is the only streamline reflecting travel through the vault itself. This streamline has the longest travel time of about 300,000 years.

The intact vault exists from time zero to 575 years. The waste container does not breach for 635 years, so the intact vault has no bearing on final transport results.

\subsection{Cracked Vault Scenario}

Figures 4.4.6 and 4.4.7 show velocity field results from the cracked vault scenario. The former figure shows the direction of the flows only, while the latter figure shows the actual magnitudes. The latter figure also shows streamlines and time markers.

The setting for this scenario varies from the intact vault scenario as follows:

- concrete roof replaced by overlying clay

- waste replaced by surface backfill

- concrete walls replaced by surrounding sand.

The surface infiltration remains constant at four $\mathrm{cm} / \mathrm{yr}$. 


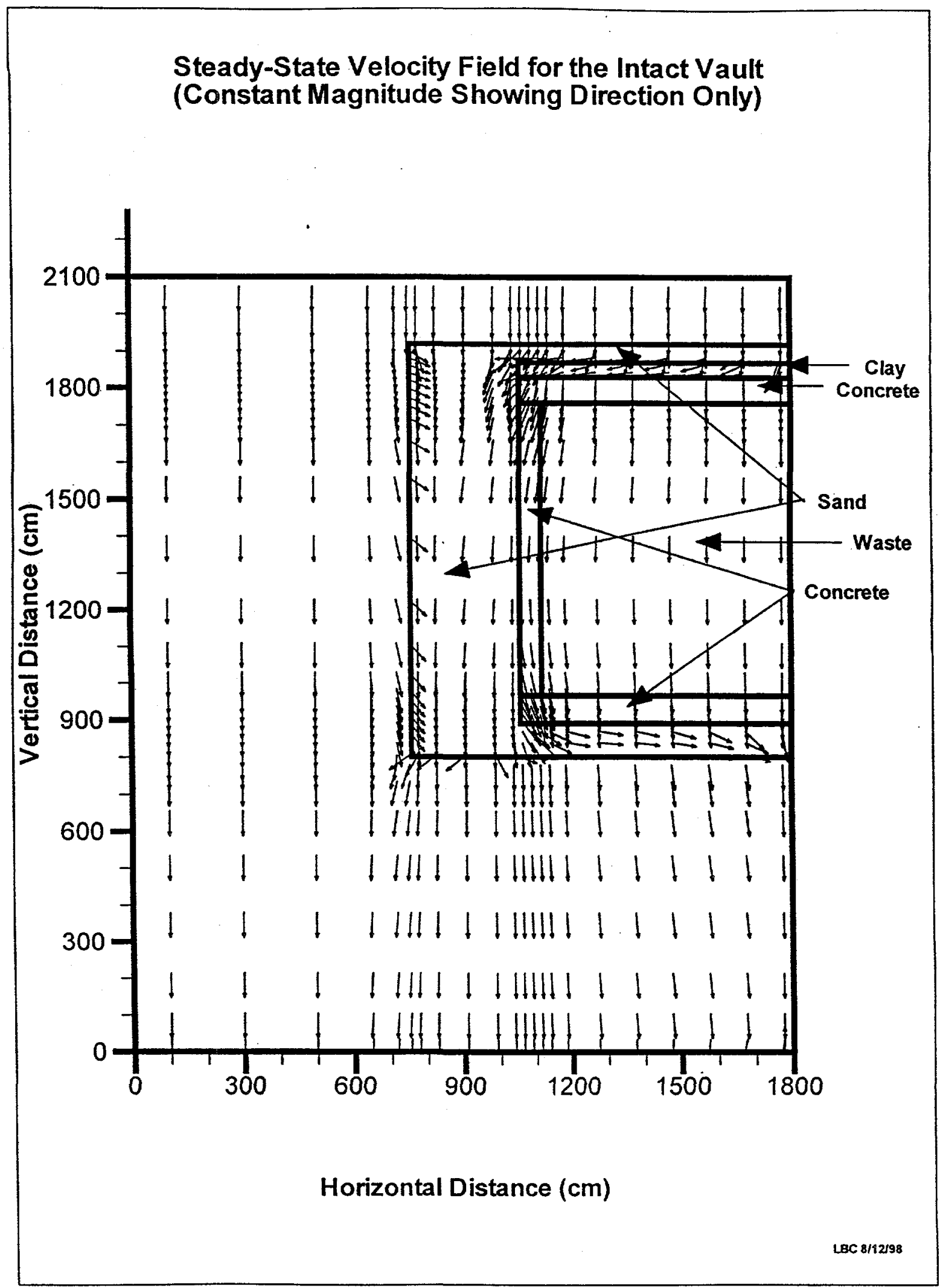

Figure 4.4.4. Flow Directions for Intact Vault 


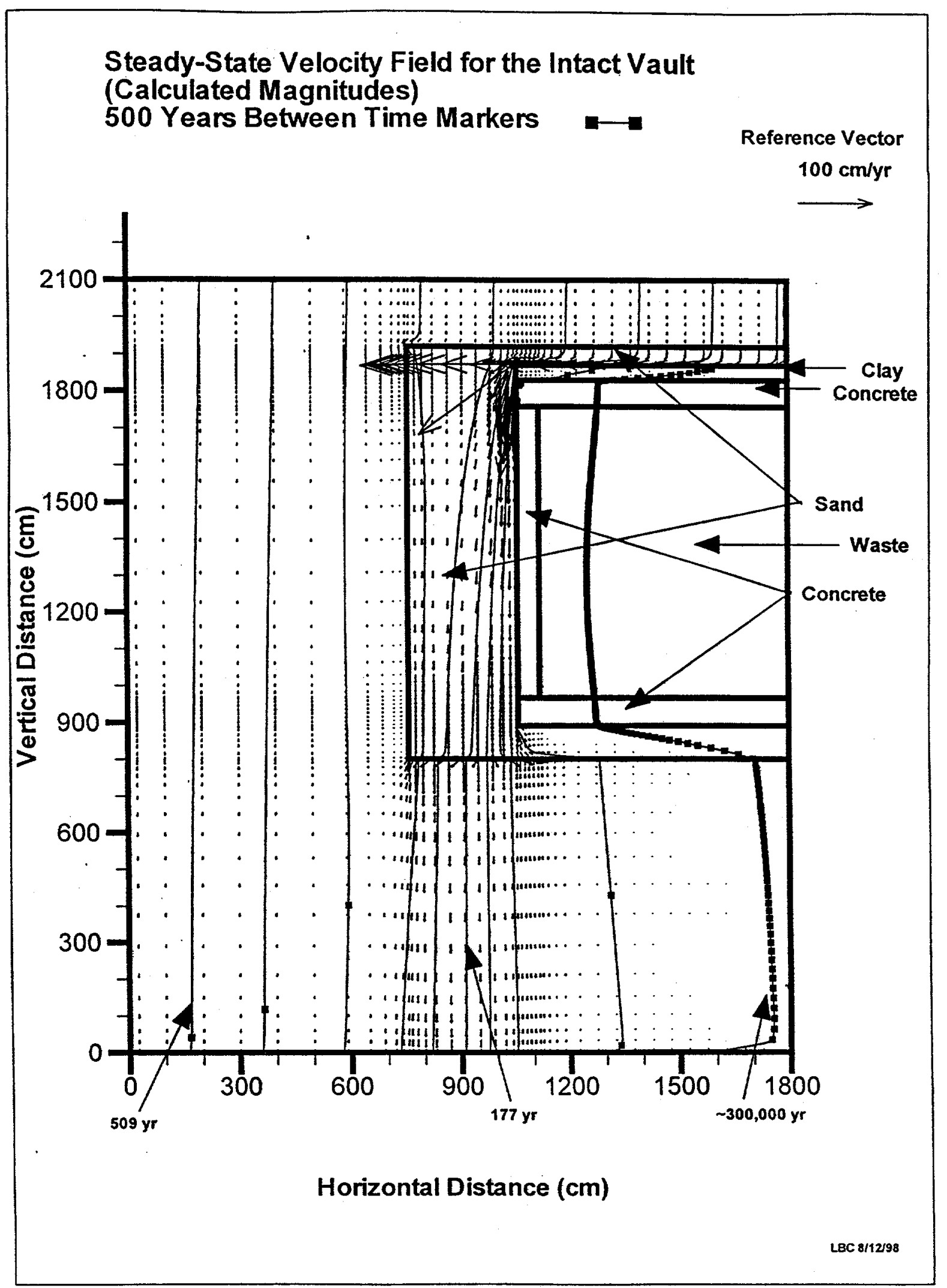

Figure 4.4.5. Velocity Flow Field and Streamlines with Time Markers for Intact Vault 
The flow patterns remain essentially the same as for the intact vault case, with a couple of exceptions. Water at the base of the waste now moves horizontally toward the lower outside edge of the waste. Three streamlines pass through the waste, versus only one for the intact case. One streamline passes through the vault wall. The shift in the streamlines shows that the water finds an easier journey through the waste, than for the intact case. This increased ease of movement is reflected by the reduced velocity magnitudes over the vault roof. The travel time through the vault is reduced from about 300,000 years to about 23,000 years. The shortest travel time, through the vertical sand layer increases from 177 years to 235 years, because that path no longer has to accommodate all the water from above the vault roof.

The velocity plots show that meteoric water infiltrating down through the surface barrier primarily skirts around the vault. The clay and sand layers over the concrete roof divert the infiltrating water, which moves horizontally to the upper left corner of the vault roof. The water then "spills" into the sand surrounding the vault, where it continues traveling down with some water being pushed away from the vault. At the base of the vault, the water turns the corner and moves horizontally beneath the base of the vault through the sand layer. At the far-left edge of the model, the flow remains unaffected by the presence of the vault as the travel time holds constant at 509 years.

The cracked vault exists from 576 years to 1050 years. The waste container does not breach until 635 years. Thus, the cracked vault is impacted by a double release rate from 636 to 1050 , or about two-thirds of the total duration of double release (414 years / 635 years).

\subsection{Failed Vault Scenario}

Figures 4.4.8 and 4.4.9 show velocity field results from the failed vault scenario. The former figure shows the direction of the flows only, while the latter figure shows the actual magnitudes. In Figure 4.4.9, the length of the vector represents a magnitude that is twice that of the vectors shown in the comparable plots for the two previous cases. The latter figure also shows streamlines and time markers.

The setting for this scenario varies from the intact vault scenario as follows:

- concrete roof replaced by backfill (overlying clay for cracked case)

- waste replaced by surface backfill (same as cracked case)

- concrete walls replaced by surrounding sand (same as cracked case)

- clay replaced by surface backfill (clay for cracked case)

- concrete floor replaced by surrounding same (concrete for cracked case)

- surface infiltration changed to $40 \mathrm{~cm} / \mathrm{yr}(4 \mathrm{~cm} / \mathrm{yr}$ for cracked case).

The velocity plots show that the sand layer sandwiched between the original backfill and the replacement backfill (for the clay, concrete roof and waste) causes some of the infiltration water to skirt around the vault. Most of the water is refracted toward the outside of the vault at the material boundary, but then readjusts and continues to travel vertically downward through the vault. Some water near the outside edge of the vault prefers to travel horizontally. through the sand layer rather than penetrating into the backfill that replaced the clay. As observed for the intact case, this water increases its speed and spills around the upper left comer of the vault (in this case the original clay corner). Water travels readily through the sand and the walls (which have been replaced by sand). Velocities through the waste are less than through the sand, especially near the outer and inner vertical edges of the waste. At the base of the sand beneath the vault, rather than turning toward the center of the vault as in the intact case, the water now travels away from the vault, increasing the flow beneath the vertical sand layer. This direction shift is identical to the shift that occurs above the vault at the interface between the sand and the backfill.

Four streamlines pass through the waste, versus only one for the intact case and three for the cracked case. One streamline passes through the vault wall as in the cracked case. The shift in the streamlines shows that the water finds an easier journey through the waste, than for the intact case.

Because the meteoric surface infiltration rate increased by an order of magnitude, from $4 \mathrm{~cm} / \mathrm{yr}$ to $40 \mathrm{~cm} / \mathrm{yr}$, the flow magnitudes must increase and the travel times must decrease. The travel time through the vault is reduced to about 294 years from about 300,000 years for the intact case and about 23,000 years for the cracked case. The shortest travel time through the vertical sand layer reduces to 33 years from 177 years for the intact case and 235 years for the cracked case. At the far-left edge of the model, the flow is relatively unaffected by the presence of the vault but the travel time decreases to 51 years from 509 years for the other two cases. This result is in accordance with the order of magnitude increase in the surface infiltration rate.

The failed vault exists from 1050 years to the end of the simulation. This represents about one-third of the time when the double release is occurring (221 years / 635 years), all the single release duration of 2,667 years, and all the post-release time. 


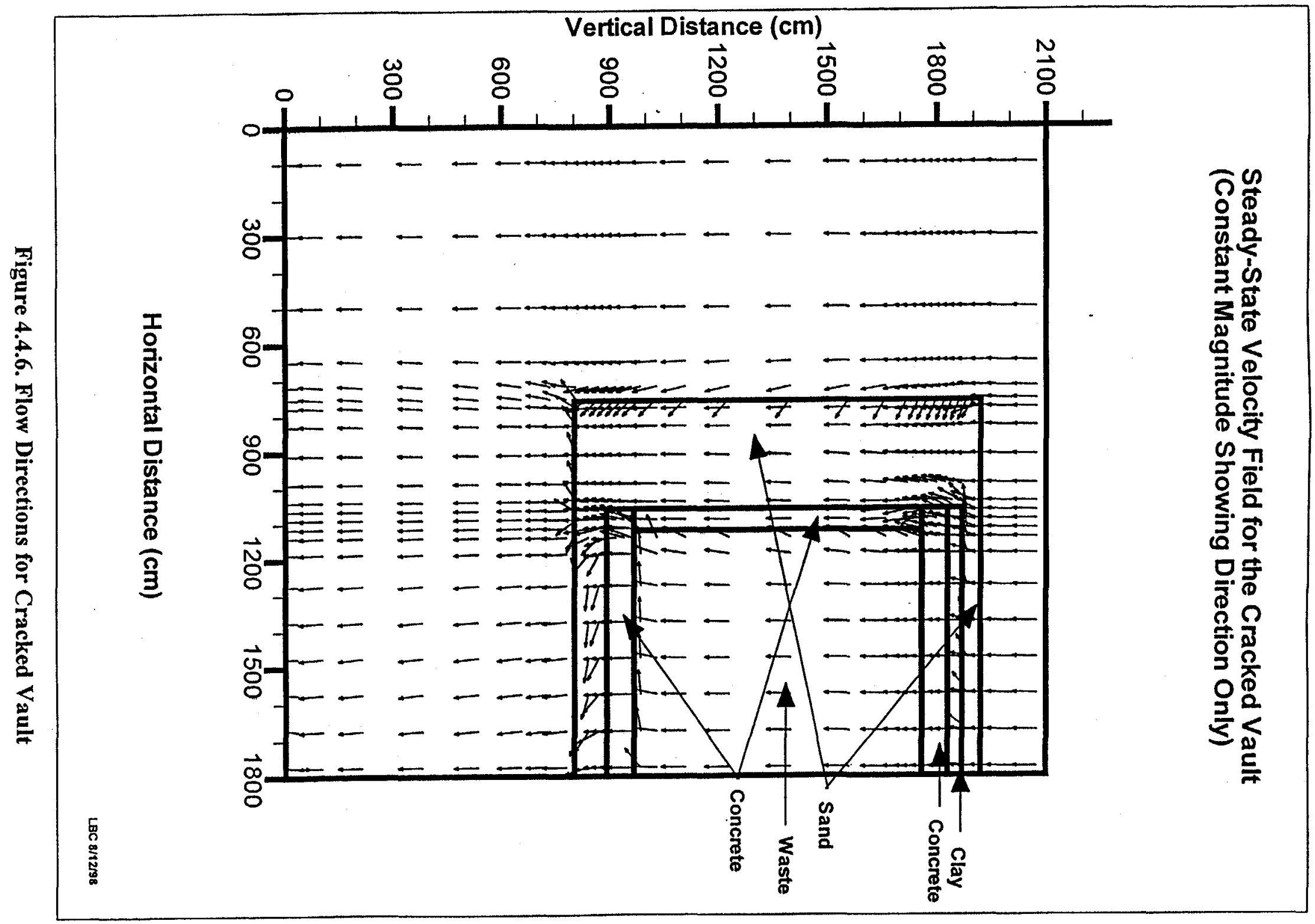




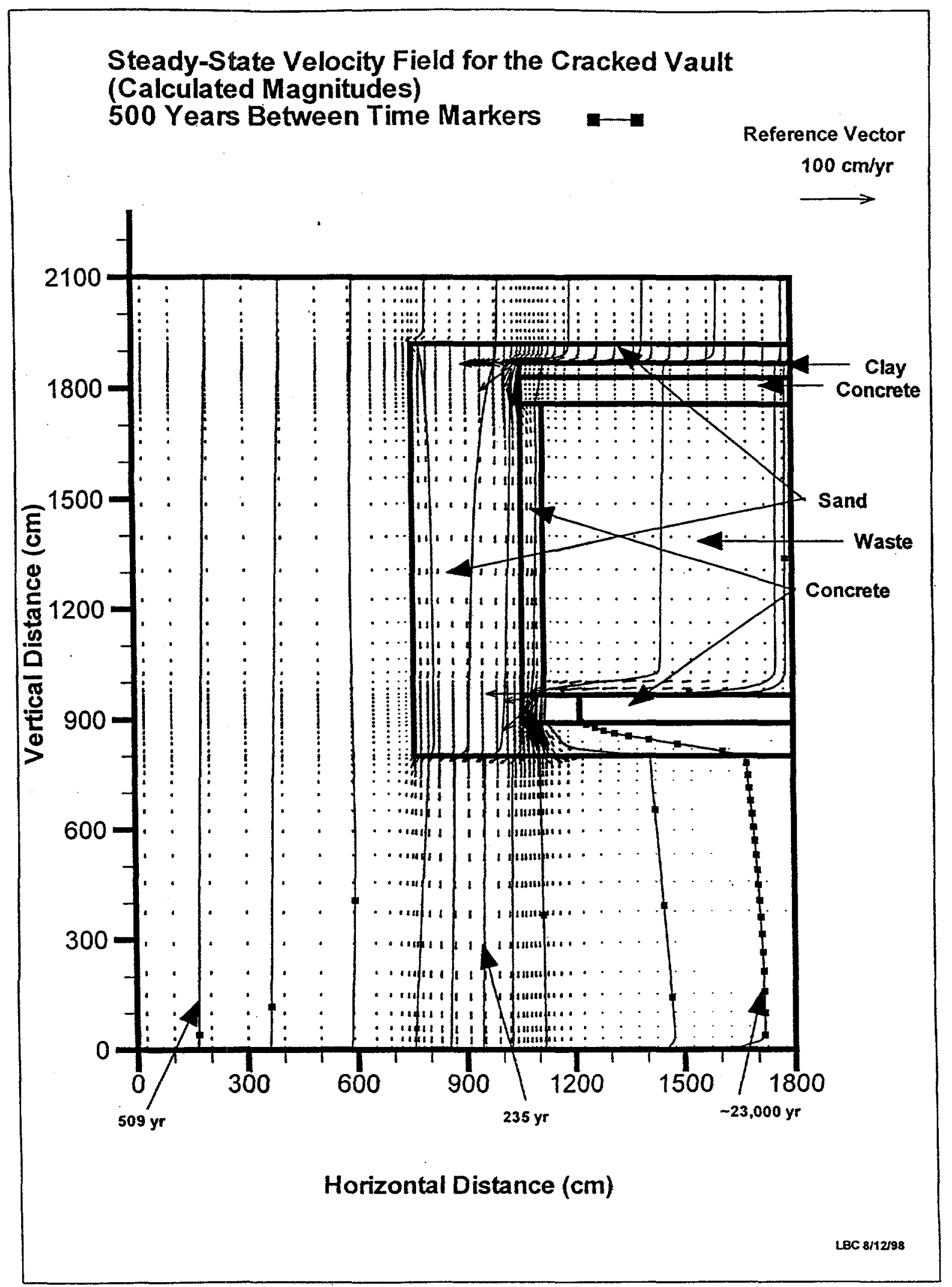

Figure 4.4.7. Velocity Flow Field and Streamlines with Time Markers for Cracked Vault 


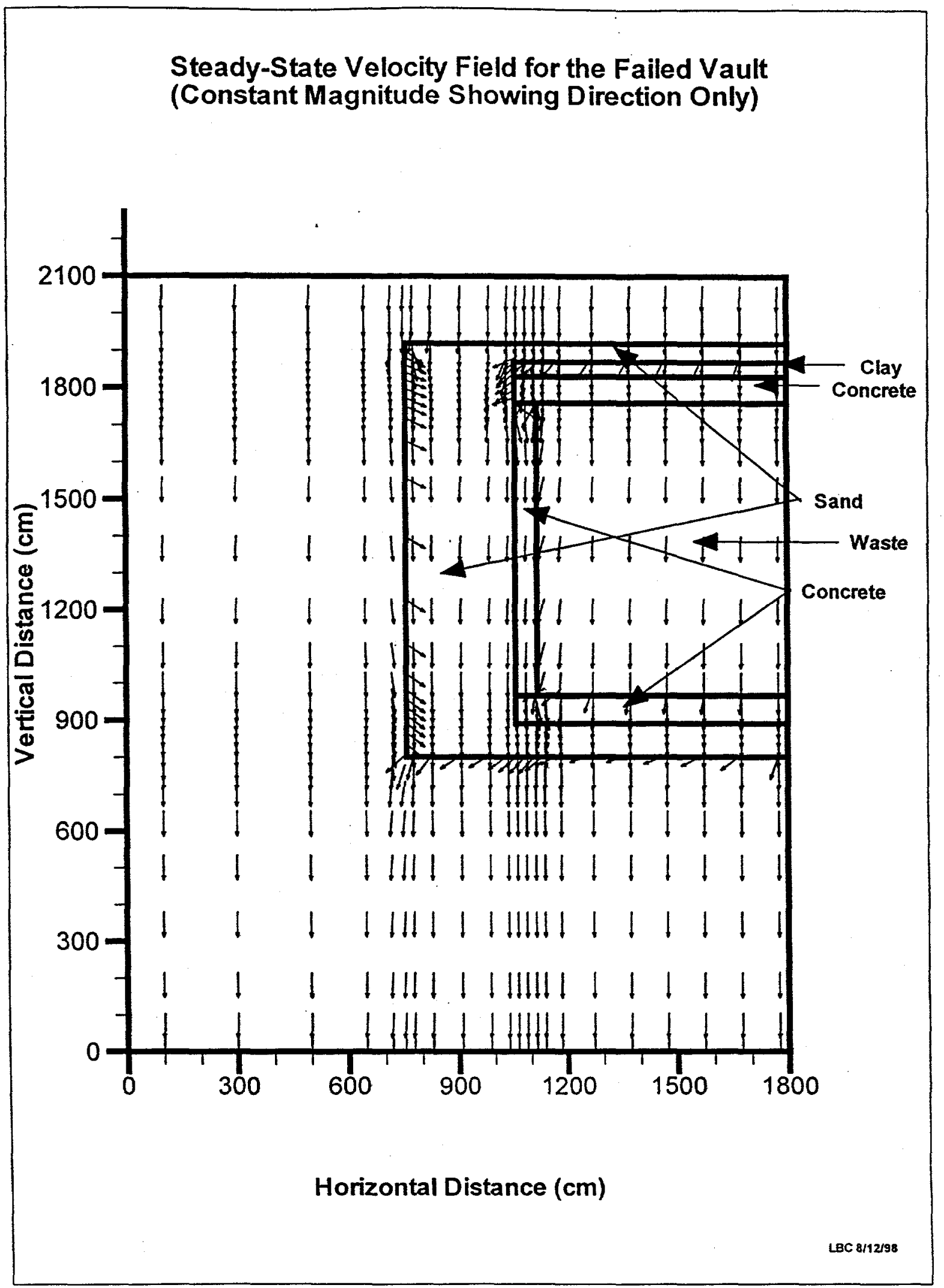

Figure 4.4.8. Flow Directions for Failed Vault 


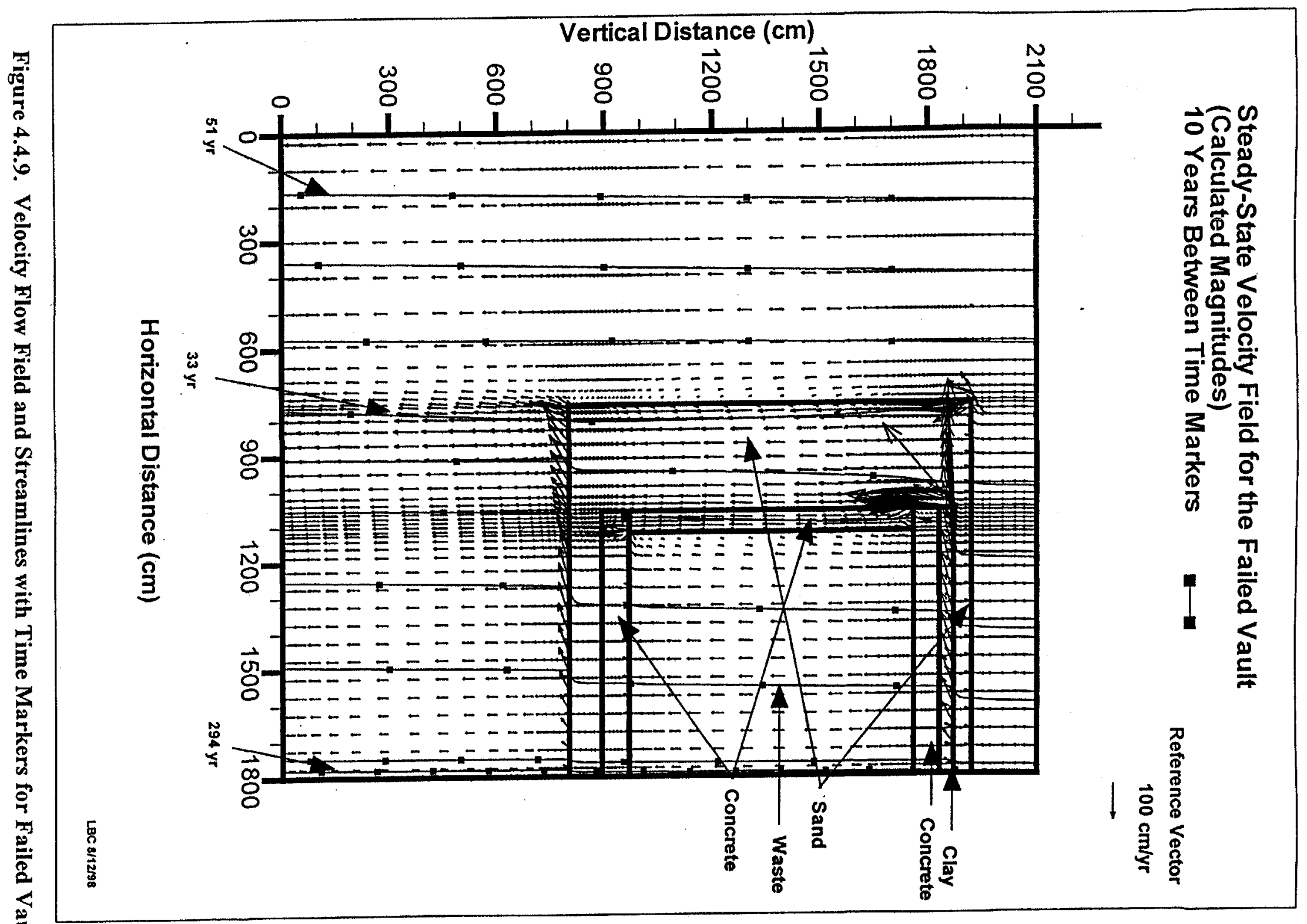




\subsection{Transport Model}

The transport model combines the flow model; the source releases from the corroding wasteforms partially restricted by the corroding waste container; the engineered materials of the waste, the vault and the barrier; and the soils and sediments. The result is a contaminant mass flux at the water table used to provide a source term to the aquifer model.

Each radionuclide remaining after the screening and scoping analyses was analyzed with a transport model. A generic model was adjusted to represent the specific properties of each radionuclide.

The modeling was performed in a manner to produce normalized results. An inventory of 1 Curie (Ci) of each radionuclide was assumed, so that results could simply be multiplied by the estimated total inventory.

The ultimate goal of the overall ground water pathway analysis was to obtain a peak concentration at a $100-\mathrm{m}$ down-gradient well to compare against an allowable ground water concentration limit. Because the time of the peak was not known a priori, the transport model initially was executed to simulate 25,000 years. When the peak flux at the water table occurred after 25,000 years, the transport analysis was extended until the peak at the water table did occur. An extra time buffer was provided to try to anticipate the additional travel time to the $100-\mathrm{m}$ down-gradient well.

The results for each contaminant are presented as a plot that includes the source release flux, the flux at the water table and the concentration at the $100-\mathrm{m}$ well obtained from the subsequent aquifer modeling. The fluxes are presented as Curies per unit Curie of inventory and are plotted versus the left $y$-axis. The concentrations are presented as $\mathrm{pCi} / \mathrm{L}$ per unit Curie of inventory and are plotted versus the right $\mathrm{y}$-axis. Only the source fluxes and the fluxes at the water table will be discussed in this section. Discussion of the concentrations at the well is provided in the transport section of the aquifer model.

Results differ among the radionuclides based primarily on three factors:
1. Decay rate
2. Retardation in the vault
3. Retardation in the sediments

\subsection{Decay Rate}

Table 4.4-5 above reveals that only five radionuclides have a half-life less than 10,000 years. Those five radionuclides are repeated by ascending half-life in Table 4.4-7. A shorter half-life, causes more rapid decay, so the source flux decreases and the peak normally occurs early. Low decay rates, i.e., long half-lives, have little impact on results.

\begin{tabular}{|l|c|c|c|c|}
\hline & \multicolumn{4}{|c|}{ Table 4.4-7. Relatively Short-Lived Radionuclides } \\
\hline & Concrete & Soil & Clay & Half-life \\
\hline Radionuclide & $(\mathrm{m} / \mathrm{g})$ & $(\mathrm{ml} / \mathrm{g})$ & $(\mathrm{m} / \mathrm{g})$ & (years) \\
\hline Si-32 & 3.5 & 35.0 & 180.0 & $3.30 \mathrm{E}+02$ \\
\hline Ho-166m & 5000.0 & 250.0 & 1300.0 & $1.20 \mathrm{E}+03$ \\
\hline Tb-158 & 240.0 & 240.0 & 240.0 & $1.20 \mathrm{E}+03$ \\
\hline Mo-93 & 0.1 & 10.0 & 90.0 & $3.50 \mathrm{E}+03$ \\
\hline C-14 & 5000.0 & 2.0 & 1.0 & $5.73 \mathrm{E}+03$ \\
\hline
\end{tabular}

\subsection{Retardation in the Vault}

Retardation, the ratio of water velocity to contaminant velocity, is directly related to the distribution coefficient by the equation

$$
R_{d}=\left(1+\rho_{b} K_{d}\right) / n
$$

Where $R_{d}$ is the retardation, $K_{d}$ is the distribution coefficient, $\rho_{b}$ is the dry bulk density and $n$ is the porosity. A high $K_{d}$ prevents a contaminant from moving rapidly, and retains much of the contaminant on the solids, thus reducing the flux and ultimately the peak concentration. The $K_{d}$ also impacts the arrival time for the peak, with a 
higher $K_{d}$ delaying the arrival time. The radionuclides with the lowest $K_{d}$ 's will move most readily and will exhibit the highest normalized peak fluxes and the highest normalized peak concentrations. Those contaminants with the lowest $\mathrm{K}_{d}$ 's in the waste and vault from Table 4.4-5 are repeated in Table 4.4-8. All other radionuclides have a $\mathrm{K}_{d}$ of $100 \mathrm{ml} / \mathrm{g}$ or greater.

\begin{tabular}{|c|c|c|c|c|}
\hline \multicolumn{5}{|c|}{ Table 4.4-8. Radionuclides with Little Retardation in the Vault } \\
\hline \multirow{3}{*}{ Radionuclide } & \multicolumn{3}{|c|}{ Distribution Coefficient $\left(\mathrm{K}_{\mathrm{d}}\right)$} & \\
\hline & Concrete & Soil & Clay & Half-life \\
\hline Be-10 & $(\mathrm{ml} / \mathrm{g})$ & $(\mathrm{m} / \mathrm{g})$ & $(\mathrm{m} / \mathrm{g})$ & (years) \\
\hline $\mathrm{K}-40$ & 0.001 & 250.0 & 1300.0 & $1.60 \mathrm{E}+06$ \\
\hline $\mathrm{Mo}-93$ & 0.001 & 15.0 & 75.0 & $1.28 \mathrm{E}+09$ \\
\hline $\mathrm{Se}-79$ & 0.1 & 10.0 & 90.0 & $3.50 \mathrm{E}+03$ \\
\hline $\mathrm{Ca}-41$ & 0.1 & 150.0 & 740.0 & $6.50 \mathrm{E}+04$ \\
\hline $\mathrm{I}-129$ & 1.0 & 5.0 & 50.0 & $1.03 \mathrm{E}+05$ \\
\hline $\mathrm{Si}-32$ & 2.0 & 1.0 & 1.0 & $1.57 \mathrm{E}+07$ \\
\hline $\mathrm{Cl}-36$ & 3.5 & 35.0 & 180.0 & $3.30 \mathrm{E}+02$ \\
\hline
\end{tabular}

\subsection{Retardation in the Sediments}

After the contaminants travel through the vault, they must still travel through the sediments to the water table and to the $100-\mathrm{m}$ down-gradient well. This distance is much greater than the distance through the waste and the vault, so it can be an important factor in magnitude and timing of the peaks at the water table and at the 100 -m well. Those contaminants with the lowest $K_{d}$ 's in the sediments from Table 4.4-5 are repeated in Table 4.4-9. All other radionuclides have a $\mathrm{K}_{d}$ of $100 \mathrm{mV} / \mathrm{g}$ or greater.

\begin{tabular}{|c|c|c|c|c|}
\hline \multirow{4}{*}{ Tadionuclide } & \multicolumn{4}{|c|}{ Distribution Coefficient $\left(\mathrm{K}_{\mathrm{f}}\right)$} \\
\cline { 2 - 5 } & Concrete & Soil & Clay & Half-life \\
\cline { 2 - 5 } & $(\mathrm{ml} / \mathrm{g})$ & $(\mathrm{ml} / \mathrm{g})$ & $(\mathrm{ml} / \mathrm{g})$ & (years) \\
\hline Tc-99 & 1000.0 & 0.1 & 1.0 & $2.13 \mathrm{E}+05$ \\
\hline $\mathrm{I}-129$ & 2.0 & 1.0 & 1.0 & $1.57 \mathrm{E}+07$ \\
\hline $\mathrm{Cl}-36$ & 20.0 & 1.7 & 1.7 & $3.01 \mathrm{E}+05$ \\
\hline $\mathrm{C}-14$ & 5000.0 & 2.0 & 1.0 & $5.73 \mathrm{E}+03$ \\
\hline $\mathrm{Ca}-41$ & 1.0 & 5.0 & 50.0 & $1.03 \mathrm{E}+05$ \\
\hline $\mathrm{Mo}-93$ & 0.1 & 10.0 & 90.0 & $3.50 \mathrm{E}+03$ \\
\hline $\mathrm{K}-40$ & 0.0 & 15.0 & 75.0 & $1.28 \mathrm{E}+09$ \\
\hline $\mathrm{Si}-32$ & 3.5 & 35.0 & 180.0 & $3.30 \mathrm{E}+02$ \\
\hline $\mathrm{Mn}-53$ & 100.0 & 50.0 & 180.0 & $3.70 \mathrm{E}+06$ \\
\hline
\end{tabular}

\subsection{Flux Plots}

The flux plot for each radionuclide is discussed below. First, the plot (Figure 4.4.10) for Be-10 is discussed. Then, a list of all the peak times and fractional fluxes sorted by the peak magnitude is presented in Table 4.4-10 and discussed. Values from Table 4.4-10 are plotted in Figure 4.4.11 and some apparent anomalies are highlighted. Then, the plot of the flux to the water table for each remaining radionuclide is described briefly.

The fractional flux ( $\mathrm{Ci}$ per unit $\mathrm{Ci}$ of inventory) released from the waste container for $\mathrm{Be}-10$ is shown in $\mathrm{Figure}$ 4.4.10. The fractional flux to the water table is plotted in Figure 4.4.10, as is the peak concentration at the 100 -m down-gradient well. The release from the waste container starts at 635 years and ends at 3,937 years. The first 635 years of the release (years 636 to 1270) have a magnitude equal to twice the corrosion rate of the wasteform. The remainder of the release duration has a release magnitude equal to the corrosion rate of the wasteform. 


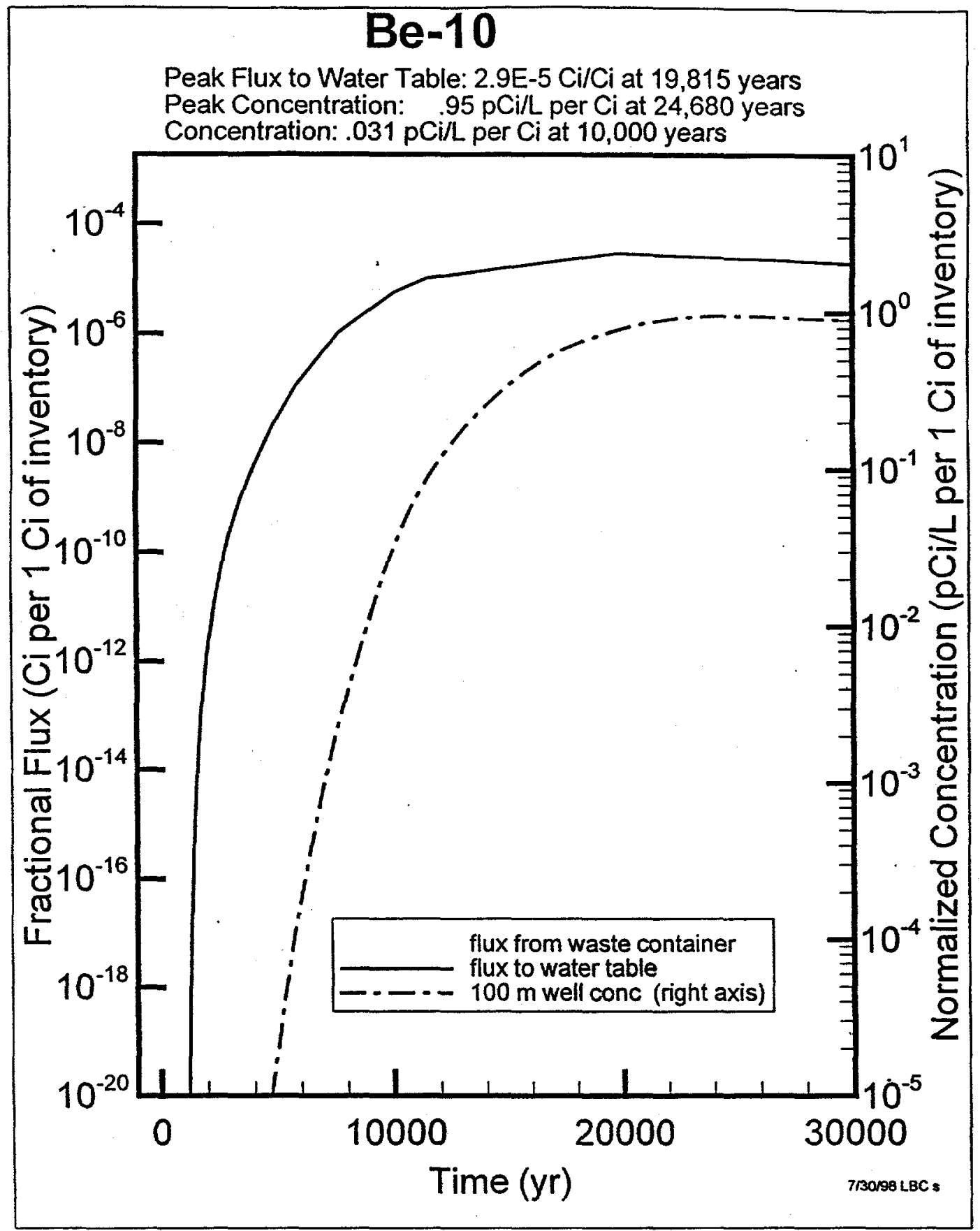

\section{Figure 4.4.10. Flux and Concentration Results for Be-10}

The fractional flux to the water table rises rapidly until about year 2,000. Until about year 10,000 the rate of increase is medium. After the year 10,000 until the peak, the rate of increase is low. The peak occurs at 19,815 years with a magnitude of $2.9 \mathrm{E}-5 \mathrm{Ci} / \mathrm{Ci}$. After the peak, the rate of decrease is low. These results are caused by the high soil $K_{d}$ of $250 \mathrm{mV} / \mathrm{g}$ that overwhelms the very low concrete $K_{d}$ of $1 . E-3 \mathrm{ml} / \mathrm{g}$.

As shown in Table 4.4-10, I-129 has the highest peak of 3.90E-4 at the earliest time of 1,051 years. The high magnitude and early time are caused by the low concrete $K_{d}$ of $2 \mathrm{ml} / \mathrm{g}$ and the low soil $\mathrm{K}_{d}$ of $1 \mathrm{ml} / \mathrm{g}$. Ca-41 is the second radionuclide with a peak of $2.70 \mathrm{E}-4$ at 1,721 years. Ca-41 has a lower concrete $K_{d}$ of $1 \mathrm{ml} / \mathrm{g}$, but the soil $K_{d}$ is five times higher at $5 \mathrm{ml} / \mathrm{g}$. $\mathrm{K}-40$ is the third radionuclide with a peak of $2.00 \mathrm{E}-4$ at 4,465 years. The peak arrives much later, because the soil $\mathrm{K}_{d}$ is $15 \mathrm{ml} / \mathrm{g}$ that slows the movement although the concrete $\mathrm{K}_{d}$ is $1.00 \mathrm{E}-3$. $\mathrm{Cl}-$ 36 is the fourth radionuclide with a peak of $1.60 \mathrm{E}-4$ at 4,495 years. $\mathrm{Cl}-36$ is slowed in the concrete with a $\mathrm{K}_{\mathrm{d}}$ of 20 , but the soil $\mathrm{K}_{d}$ of $1.7 \mathrm{mV} / \mathrm{g}$ is only higher than that of Tc-99 and I-129. Mo-93 is the fifth radionuclide with a peak 
of 1.57E-4 at 1,897 years. Mo-93 has a very low concrete $\mathrm{K}_{d}$ of $0.1 \mathrm{ml} / \mathrm{g}$, but its soil $\mathrm{K}_{d}$ of $10 \mathrm{mV} / \mathrm{g}$ is less that that of $\mathrm{K}-40$. However, Mo-93 has a relatively short half-life of 3,500 years that causes its early peak that is less than that of K-40. Se-79 is sixth on the list with a peak of $4.20 \mathrm{E}-5$ at 12,715 years. Se-79 has a very low concrete $\mathrm{K}_{d}$ of $0.1 \mathrm{ml} / \mathrm{g}$, but the soil $K_{d}$ of $150 \mathrm{ml} / \mathrm{g}$ slows it.

The top six radionuclides on the list have peaks within one order of magnitude of the first one, I-129. None of these has a $K_{d}$ greater than 20 , except for Se-79 which has a $K_{d}$ of $150 \mathrm{mV} / \mathrm{g}$ in the soil that is somewhat offset by a $\mathrm{K}_{d}$ of 0.1 in the concrete (Table 4.4-8). All other radionuclides have peaks that are at least one order of magnitude less than I-129 and will be discussed with their individual plot. All other radionuclides have at least one $K_{d}$ greater than $100 \mathrm{ml} / \mathrm{g}$ except for Si-32, which has a half-life of 330 years.

If a radionuclide has either the concrete or the soil $K_{d}$ greater than $100 \mathrm{mV} / \mathrm{g}$, then the peak occurs after 10,000 years. That peak is more than one order of magnitude less than $1-129$, except for Se-79, which has a $K_{d}$ of .I in the concrete. If either $\mathrm{K}_{d}$ for a particular radionuclide exceeds $1,000 \mathrm{mV} / \mathrm{g}$, then the peak occurs after 100,000 years, except for C-14 with a half-life of 5,730 years and $H 0-166 \mathrm{~m}$ with a half-life of 1,200 years. Peaks after 100,000 years are at least two orders of magnitude less than I-129's peak, except for Al-26, which is .00105 of the I-129 peak.

Some apparent anomalies arise in the table and bear further discussion. Tc-99 has a peak slightly lower than Al-26, but it occurs 80,000 years earlier. Tc-99 has the lowest soil $K_{d}$ of $0.1 \mathrm{ml} / \mathrm{g}$, but its concrete $\mathrm{K}_{d}$ of $1,000 \mathrm{ml} / \mathrm{g}$ greatly retards its exit from the vault. Most other radionuclides with similar peak magnitudes have high soil $\mathrm{K}_{d}$ 's, e.g., Al26 's $1,500 \mathrm{ml} / \mathrm{g}$ and $\mathrm{Pb}-202$ 's $270 \mathrm{ml} / \mathrm{g}$. The soil $\mathrm{K}_{\mathrm{d}}$ 's operate over a much greater length that results in later arrival times. All the other apparent anomalies are caused by relatively short half-lives. Those radionuclides are $\mathrm{Nb}-94$, Si-32, C-14, Tb-158, and Ho- $166 \mathrm{~m}$.

\section{Table 4.4-10. Peak Fluxes at Water Table versus Times}

\begin{tabular}{|l|r|r|l|}
\hline \multicolumn{1}{|c|}{ Nuclide } & Time (yr.) & Peak (CiCi) & \multicolumn{1}{|c|}{ Comments } \\
\hline $\mathrm{I}-129$ & 1,051 & $3.90 \mathrm{E}-04$ & Low $\mathrm{K}_{d}$ in concrete and soil \\
\hline $\mathrm{Ca}-41$ & 1,721 & $2.70 \mathrm{E}-04$ & \\
\hline $\mathrm{K}-40$ & 4,465 & $2.00 \mathrm{E}-04$ & \\
\hline $\mathrm{Cl}-36$ & 4,495 & $1.60 \mathrm{E}-04$ & \\
\hline $\mathrm{Mo}-93$ & 1,897 & $1.57 \mathrm{E}-04$ & 3,500 year half-life \\
\hline Se-79 & 12,715 & $4.20 \mathrm{E}-05$ & \\
\hline Be-10 & 19,815 & $2.90 \mathrm{E}-05$ & \\
\hline $\mathrm{Mn}-53$ & 17,415 & $2.90 \mathrm{E}-05$ & \\
\hline Fe-60 & 32,486 & $1.70 \mathrm{E}-05$ & \\
\hline $\mathrm{Ni}-59$ & 44,245 & $8.80 \mathrm{E}-06$ & \\
\hline $\mathrm{Pb}-205$ & 79,720 & $5.80 \mathrm{E}-06$ & \\
\hline $\mathrm{Pb}-202$ & 69,545 & $4.90 \mathrm{E}-06$ & \\
\hline Al-26 & 124,180 & $4.10 \mathrm{E}-06$ & \\
\hline Tc-99 & 41,845 & $3.10 \mathrm{E}-06$ & high concrete $\mathrm{K}_{\mathrm{d}}$ \\
\hline $\mathrm{Nb}-94$ & 27,430 & $1.80 \mathrm{E}-06$ & 20,300 year half-life \\
\hline Sm-146 & 407,300 & $7.20 \mathrm{E}-07$ & \\
\hline $\mathrm{Hf}-182$ & 423,000 & $6.90 \mathrm{E}-07$ & \\
\hline $\mathrm{Zr}-93$ & 336,300 & $5.80 \mathrm{E}-07$ & \\
\hline La-137 & 127,000 & $3.10 \mathrm{E}-07$ & \\
\hline $\mathrm{Si}-32$ & 2,685 & $8.00 \mathrm{E}-08$ & 330 year half-life \\
\hline $\mathrm{C}-14$ & 14,215 & $3.20 \mathrm{E}-08$ & 5,730 year half-life \\
\hline Tb-158 & 10,715 & $4.10 \mathrm{E}-10$ & 1,200 year half-life \\
\hline $\mathrm{Ho}-166 \mathrm{~m}$ & 16,900 & $4.20 \mathrm{E}-13$ & 1,200 year half-life \\
\hline & & & \\
\hline
\end{tabular}

Revisiting Table 4.4-7 showing short-lived radionuclides, each of the radionuclides with a short half-life has a shortened peak arrival time and a reduced peak. All the entries from Table 4.4-8 showing radionuclides with a low concrete $K_{d}$, had an arrival time of less than 5,000 years. The top 7 entries from Table 4.4-10 match entries from Table 4.4-8, with only Si-32 not having a high peak, because of its 330 -year half-life. Six of the entries from Table 
4.4-9 showing radionuclides with a low soil $K_{d}$, are among the top eight peaks on Table 4.4-10. The three exceptions are Tc-99 with its high $\mathrm{K}_{\mathrm{d}}$ of $1000 \mathrm{~m} / \mathrm{g}$ in the concrete, C- 14 with its high $\mathrm{K}_{\mathrm{d}}$ of $5,000 \mathrm{~m} / \mathrm{g}$ in the concrete, and Si-32 with its short half-life of 330 years. The two other spots in the top eight on Table 4.4-10 were filled by $\mathrm{Se}-79$ and $\mathrm{Be}-10$, which are both members of Table 4.4-8 with low concrete $\mathrm{K}_{d}$ 's.

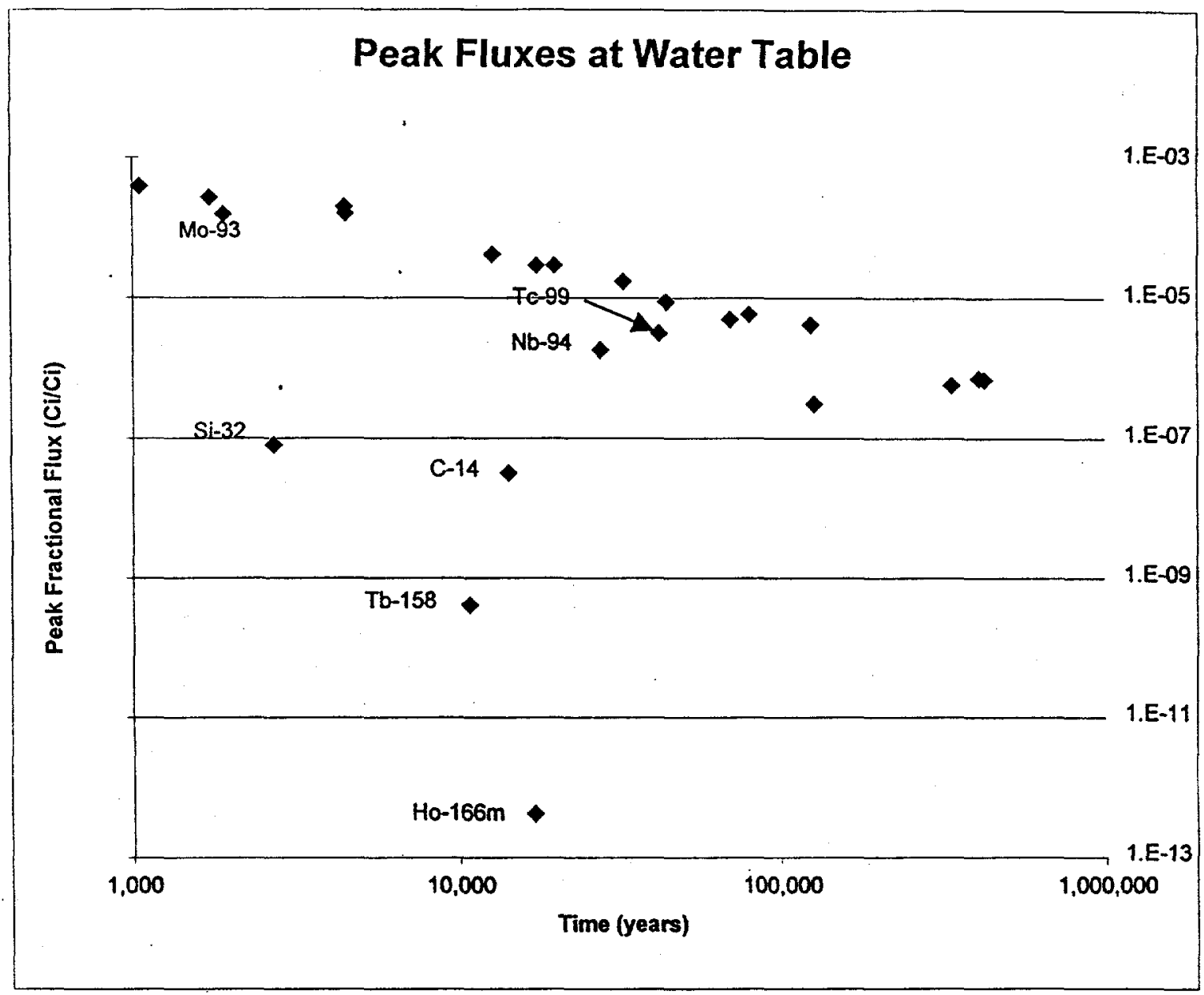

Figure 4.4.11. Peak Fluxes at Water Table vs. Time

Figure 4.4.12 shows the results for $\mathrm{C}-14$. Figures 12 through 33 showing the fractional fluxes and normalized concentrations are included at the end of section 4.4. The source fractional flux slants down to the right, reflecting its 5,730-year half-life. The peak of 3.2E-8 Ci/Ci occurs at 14,215 years.

Figure 4.4.13 shows the results for Al-26. The peak of 4.1E-6 $\mathrm{Ci} / \mathrm{Ci}$ occurs at 124,180 years, because $\mathrm{Al}-26$ has the highest soil $\mathrm{K}_{\mathrm{d}}$ of $1500 \mathrm{~mL} / \mathrm{g}$.

Figure 4.4.14 shows the results for Si-32. The source fractional flux slants sharply down to the right, due to the radionuclide's 330 -year half-life. The peak of $8.0 \mathrm{E}-8 \mathrm{Ci} / \mathrm{Ci}$ occurs at 2,685 years and is sharper than the peaks for the other radionuclides.

Figure 4.4.15 shows the results for Cl-36. The relatively high peak of $1.6 \mathrm{E}-4$ occurs at 4,495 years. A spike in the flux to the water table curve appears at about 1,000 years. The spike is caused by the change from a cracked vault to a failed vault scenario at 1,050 years. At 1,050 years, the velocities and volumes of water present in the model are greatly altered. The increased vertical velocities likely drive contaminants that are below the vault quickly to the water table. After the spike, the concentrations and fluxes rapidly drop and the contaminant profile gradually reestablishes a state of equilibrium approximately the same as before the spike.

Figure 4.4.16 shows the results for $\mathrm{K}-40$. The relatively high peak of $2.0 \mathrm{E}-4 \mathrm{Ci} / \mathrm{Ci}$ occurs at 4,465 years. 
Figure 4.4.17 shows the results for $\mathrm{Ca}-41$. The relatively high peak of $2.7 \mathrm{E}-4 \mathrm{Ci} / \mathrm{Ci}$ appears at 1,721 years, soon after the source release drops in half at 1,270 years. The water table flux starts rapidly decreasing at about 4,200 years, about 200 years after the source term finishes releasing at 3,937 years. The spike at about 1,000 years is clearly visible, because of the short duration plotted. . The spike is caused by the change from a cracked vault to a failed vault scenario at 1,050 years. At 1,050 years, the velocities and volumes of water present in the model are greatly altered. The increased vertical velocities likely drive contaminants that are below the vault quickly to the water table.

Figure 4.4.18 shows the results for $\mathrm{Mn}-53$. The peak of $2.9 \mathrm{E}-5 \mathrm{Ci} / \mathrm{Ci}$ occurs at 17,415 years.

Figure 4.4.19 shows the results for $\mathrm{Ni}-59$. The peak of $8.8 \mathrm{E}-6 \mathrm{Ci} / \mathrm{Ci}$ occurs at 44,245 years.

Figure 4.4.20 shows the results for $\mathrm{Fe}-60$. The peak of $1.7 \mathrm{E}-5 \mathrm{Ci} / \mathrm{Ci}$ occurs at 32,486 years.

Figure 4.4.21 shows the results for Se-79. The peak of $4.2 \mathrm{E}-5 \mathrm{Ci} / \mathrm{Ci}$ occurs at 12,715 years.

Figure 4.4.22 shows the results for Mo-93. The relatively high peak of $1.6 \mathrm{E}-4 \mathrm{Ci} / \mathrm{Ci}$ occurs at 1,897 years. The slanting source release curve shows the short half-life of 3,500 years. The water table flux almost matches the source release flux starting about 1,400 years. This is likely a reflection of the low soil $\mathrm{K}_{d}$ of $10 \mathrm{ml} / \mathrm{g}$ and the short half-life.

Figure 4.4 .23 shows the results for $\mathrm{Nb}-94$. The peak of $1.8 \mathrm{E}-6 \mathrm{Ci} / \mathrm{Ci}$ occurs at 27,430 years.

Figure 4.4.24 shows the results for $\mathrm{Zr}-93$. The peak of $5.8 \mathrm{E}-7 \mathrm{Ci} / \mathrm{Ci}$ occurs at 336,300 years, because of its very high concrete $K_{d}$ of $5,000 \mathrm{mV} / \mathrm{g}$ combined with a high soil $K_{d}$ of $600 \mathrm{ml} / \mathrm{g}$.

Figure 4.4.25 shows the results for TC-99. The peak of 3.1E-6 $\mathrm{Ci} / \mathrm{Ci}$ occurs at 41,845 years.

Figure 4.4.26 shows the results for $\mathrm{I}-129$. The peak of $3.9 \mathrm{E}-4 \mathrm{Ci} / \mathrm{Ci}$ is the highest among all the radionuclides analyzed and occurs at the earliest time - 1,051 years. These results are caused by the low concrete $\mathrm{K}_{d}$ of $2 \mathrm{mV} / \mathrm{g}$ accompanied by the low soil $\mathrm{K}_{d}$ of $1 \mathrm{ml} / \mathrm{g}$. The water table flux curve actually is higher than the source release flux curve starting at about 1,300 years, showing the higher release from 635 years to 1270 years quickly reaching the water table. Shortly after 1,000 years, a spike in the water table flux curve is evident as also noted for Cl-36.

Figure 4.4.27 shows the results for La-137. The peak of 3.1E-7 Ci/Ci occurs at 127,000 years, reflecting a high concrete $K_{d}$ of $1,200 \mathrm{ml} / \mathrm{g}$ combined with a high soil $K_{d}$ of $1,200 \mathrm{mV} / \mathrm{g}$.

Figure 4.4.28 shows the results for Sm-146. The peak of 7.2E-7 Ci/Ci occurs at 407,300 years, reflecting a high concrete $\mathrm{K}_{d}$ of $5,000 \mathrm{ml} / \mathrm{g}$ combined with a high soil $\mathrm{K}_{d}$ of $245 \mathrm{ml} / \mathrm{g}$.

Figure 4.4.29 shows the results for $\mathrm{Tb}-158$. The relatively low peak of $4.1 \mathrm{E}-10 \mathrm{Ci} / \mathrm{Ci}$ occurs at 10,715 years. The slanting source release curve shows the short half-life of 1,200 years. The short half-life affects the peak time, because $\mathrm{Tb}-158$ has a high concrete $\mathrm{K}_{d}$ of $240 \mathrm{mV} / \mathrm{g}$ and a high soil $\mathrm{K}_{\mathrm{d}}$ of $240 \mathrm{mV} / \mathrm{g}$.

Figure 4.4.30 shows the results for Ho-166m. The very low peak of $4.2 \mathrm{E}-13 \mathrm{Ci} / \mathrm{Ci}$ occurs at 16,900 years. The slanting source release curve shows the short half-life of 1,200 years. The short half-life affects the peak time, because Ho- $166 \mathrm{~m}$ has a high concrete $K_{d}$ of $5,000 \mathrm{mV} / \mathrm{g}$ and a high soil $K_{d}$ of $250 \mathrm{mV} / \mathrm{g}$.

Figure 4.4.31 shows the results for $\mathrm{Hf}-182$. The peak of $6.9 \mathrm{E}-7 \mathrm{Ci} / \mathrm{Ci}$ occurs at 423,000 years, reflecting a high concrete $K_{d}$ of $5,000 \mathrm{ml} / \mathrm{g}$ combined with a high soil $\mathrm{K}_{d}$ of $450 \mathrm{ml} / \mathrm{g}$.

Figure 4.4.32 shows the results for $\mathrm{Pb}-202$. The peak of $4.9 \mathrm{E}-6 \mathrm{Ci} / \mathrm{Ci}$ occurs at 69,445 years.

Figure 4.4.33 shows the results for $\mathrm{Pb}-205$. The peak of $5.8 \mathrm{E}-6 \mathrm{Ci} / \mathrm{Ci}$ occurs at 79,720 years. 


\subsubsection{Aquifer Modeling}

The aquifer model was based on the revised E-Area PA ${ }^{3}$ model with appropriate changes to accommodate different radionuclides produced by the APT process. Other differences involve the assumed vault configuration, and the need only to obtain results at the 100 -m down-gradient well.

\subsubsection{Sources}

Sources for the aquifer model consist of radionuclides entering at the water table. The results from the vadose zone model are used as direct source inputs to the aquifer model.

The aquifer model includes all soils and sediments from the ground surface to the base of the Gordon aquifer to account for surface infiltration. The radionuclide fluxes from the vadose zone model are placed in the first cell of the aquifer model that is completely below the water table.

Each ILT Vault is approximately $17-\mathrm{m}$ long by $15-\mathrm{m}$ wide. In the long direction, the ILT Vaults are adjacent to a laydown area about $10-\mathrm{m}$ wide that connects to ILNT Vaults on the other side. Lateral spacing between vaults in the short direction (width) is about $300-\mathrm{ft}(91 \mathrm{~m})$ to $400-\mathrm{ft}(122 \mathrm{~m})$. Assuming the smaller lateral spacing and a $10-$ $\mathrm{m}$ wide buffer in the long direction, the effective footprint for each ILT Vault is $37-\mathrm{m}$ long $(17-\mathrm{m}+10-\mathrm{m}+10 \mathrm{~m})$ by $106-\mathrm{m}(15-\mathrm{m}+91 \mathrm{~m})$, or $3,922 \mathrm{~m}^{2}$. The footprint for two vaults is $7,844 \mathrm{~m}^{2}$. The footprint of the aquifer source node is $61-\mathrm{m}(200 \mathrm{ft})$ by $61-\mathrm{m}(200 \mathrm{ft})$, or $3,721 \mathrm{~m}^{2}$. The effect of placing the flux at the water table into an aquifer source node that has a smaller footprint than the vaults is to effectively increase the concentration, which produces conservative results.

\subsubsection{Geometry}

The geometry is based on a chunk of the General Separations Area (GSA) extending from upgradient of the vault area to slightly beyond the seepline at Upper Three Runs (UTR). The direction toward the seepline represents the $\mathrm{Y}$-axis. The $\mathrm{X}$-axis is perpendicular to the $\mathrm{Y}$-axis and is aligned horizontally. The $\mathrm{Z}$-axis is aligned vertically. The GSA model covers an area bounded by Fourmile Branch on the south, Upper Three Runs on the north, F-area on the west, and McQueen Branch on the east, from ground surface to the bottom of the Gordon aquifer.

\subsection{Flow Model}

Flach and Harris (1997) summarize the flow model geometry. "The areal resolution of the flow model is $200 \mathrm{ft}$ square except in peripheral areas. There are 108 elements along the east-west axis, and 77 elements along the northsouth axis. The 'upper' aquifer zone of the UTR aquifer unit is represented with 9 finite-elements in the vertical direction. The vadose zone is included in the model. The 'lower' aquifer zone contains 5 finite-elements while the ' $\tan$ clay' confining zone separating the aquifer zones is modeled with 2 vertical elements. The Gordon confining and aquifer units each contain 2 elements, for a total of 20 vertical elements from ground surface to the bottom of the Gordon aquifer. The 3D mesh size is therefore $108 \times 77 \times 20=166,320$ elements or $109 \times 78 \times 21=178,542$ nodes. The relatively fine vertical resolution of the model is designed to support subsequent contaminant transport analyses." Flach and Harris ${ }^{17}$ provide details of the flow model.

\subsection{Transport Model}

The transport model is a subset of the flow model, extending from the slightly upgradient of the vaults to slightly beyond the seepline at Upper Three Runs. The transport model is defined by 50 cells in the X-direction that are each 200 feet wide. The model is defined by 48 cells in the Y-direction that are each 200 feet long. The model is defined by 20 cells in the Z-direction that vary in height. The model extends from the ground surface to the base of the Gordon aquifer, so the 20 cells expand and contract in height to accommodate that overall height. When the ground surface dips below a creek, the cell heights shrink considerably. The minimum cell height is about oneninth of a foot or 1.33 inches. This model geometry was identical to that used for the E-Area PA revision.

Initial transport runs spanning 10,000 years required several weeks to complete for some radionuclides. Subsequently, a sub-model was developed to capture the subsurface from the vault area to the 100 -m down-gradient well with a much smaller buffer. The cell sizes were retained, but the outlying cells were excised. The boundary conditions (described below) were appropriately revised. Sub-model results from two radionuclides were compared with the big model results for the same two radionuclides. Result plots showed no changes. Output data files were examined and revealed no changes occurred before the eighth significant digit. The sub-model was used for all other analyses. The sub-model consists of a grid of cells consisting of 3 cells in the X-direction, 5 cells in the Ydirection and 20 cells in the $Z$-direction. 


\subsubsection{Material Properties}

Flach and Harris ${ }^{17}$ describe flow model material properties. The properties are varied on a cell-by-cell basis to take advantage of thousands of pieces of data from field and laboratory information and to produce a calibrated model.

For transport modeling, the hydraulic conductivities are not required, so the model was simplified. Only two types of materials were specified. Sand was the default material type, but clay was specified if the saturated hydraulic conductivity in the vertical direction was below $1 . \mathrm{E}-7 \mathrm{~cm} / \mathrm{sec}$.

An effective porosity of 0.25 was used for both material types, this is slightly below the average porosity of about $0.35^{19}$. A particle density of $2.65 \mathrm{~g} / \mathrm{cc}$ was assigned to both material types. The longitudinal and transverse dispersivities were set to zero for both material types, because the relatively large cell size generated numerical dispersion.

\subsubsection{Contaminant Properties}

For each radionuclide, a molecular diffusivity of $0.170 \mathrm{ft}^{2} / \mathrm{yr}\left(5 \mathrm{E}-6 \mathrm{~cm}^{2} / \mathrm{sec}\right)$ was assigned for sand, and $0.085 \mathrm{ft}^{2} / \mathrm{yr}$ $\left(2.5 \mathrm{E}-6 \mathrm{~cm}^{2} / \mathrm{sec}\right)$ for clay. The distribution coefficient and half-life for each radionuclide were listed previously in Table 4.4-5.

\subsubsection{Boundary and Initial Conditions}

Boundary conditions are prescribed around the perimeter of the modeling domain. As the name implies, the initial conditions are applied at time zero.

\subsection{Flow Model}

The flow model was solved for steady state conditions; hence, the initial conditions did not impact the results. The boundary conditions took advantage of the surrounding streams to specify zero flow conditions at those locations. Constant hydraulic head conditions were assigned to most other boundaries, based on hydraulic head contour maps. The top surface was described by combined recharge/drain boundary conditions to accommodate ground water discharges to surface water and recharge from surface water and meteoric water. The base of the model is assigned a general head boundary condition to account for flow interactions with the Crouch Branch confining unit.

\subsection{Transport Model}

The initial conditions for the transport model are zero concentrations everywhere. Boundary conditions of zero mass flux were assigned at all edges of the model. This condition is applied only for diffusion, stating that no contamination can exit the model domain via diffusion. Contamination can still exit by advection, where the water transports the contaminant. The boundary condition is conservative, because more material is held within the modeling domain than would normally happen, thus increasing concentrations within the domain.

\subsubsection{Modeling Results}

The flow model analyses culminated in generating a steady-state flow field through the aquifer. These results provide the advective driver to transport the contaminants from the water table to the $100-\mathrm{m}$ well. The transport model analyses culminated in generating normalized concentrations at the 100 -well for each radionuclide that remained after the screening and scoping analyses. The normalized concentrations are expressed in terms of pCi/L for each unit Curie of inventory. The results for each model are discussed below.

\subsection{Flow Model}

The flow model using the FACT computer program generated volumetric water fluxes through the sides of each cell under steady-state conditions. These fluxes were transferred to the PORFLOW program for use in the transport program. Near the vault, flow primarily moves horizontally toward Upper Three Runs. The vertical flow component is directed downward near the vault, but much less rapidly than the horizontal flow. Details of the flow model results are presented in Flach and Harris ${ }^{17}$.

\subsection{Transport Model}

The transport model combines the flow model, the sources at the water table, generated by the vadose zone model and the soils and the sediments. The result is a normalized contaminant concentration at the $100-\mathrm{m}$ well. The normalized contaminant concentration ( $\mathrm{pCi} / \mathrm{L}$ per unit $\mathrm{Ci}$ of inventory) is multiplied by the inventory to generate a concentration. 
Several locations $100-\mathrm{m}$ down-gradient were monitored to ensure that the peak concentration was selected. The down-gradient locations were spaced both horizontally and vertically. The peak location was in the primary flow direction, toward Upper Three Runs, in the same cell plane as the source node.

Each radionuclide remaining after the screening and scoping analyses was analyzed with a transport model. A generic model was adjusted to represent the specific properties of each radionuclide.

The ultimate goal of the overall ground water pathway analysis was to obtain a peak concentration at a $100-\mathrm{m}$ down-gradient well to compare against an allowable ground water concentration limit. The peak concentration within the first 10,000 years was required for that comparison. If the peak concentration occurred after 10,000 years, then both the highest normalized concentration during the first 10,000 years and the peak normalized concentration were reported. The time of the peak was reported.

The results for each contaminant are presented as a plot that includes the normalized concentration at the $100-\mathrm{m}$ well, the source release flux and the flux at the water table from the prior vadose zone modeling. The plots were presented earlier as Figures 10, and 12 through 33 . The normalized concentrations are presented as $\mathrm{pCi} / \mathrm{L}$ per unit Curie of inventory and are plotted versus the right $y$-axis. The flux plots are plotted versus the left $y$-axis.

Results differ among the radionuclides based primarily on three factors:

1. Flux at the Water Table

2. Decay Rate

3. Retardation in the Aquifer

\subsection{Flux at the Water Table}

The flux at the water table represents the journey from the wasteform, through the vault and sediments to the aquifer. Differences among the radionuclides of flux at the water table are primarily functions of the decay rate, the retardation in the vault and the retardation in the sediments. The flux differences were discussed above in section 4.2.1.6.2 Transport Model. The flux differences are shown the flux plot figures.

\subsection{Decay Rate}

Decay rates for relatively short-lived radionuclides were presented in Table 4.4-7. The effects noted in section 4.2.6.2.1 for the vadose zone will continue for the aquifer. In many cases, if the travel time in the aquifer is short relative to the travel time in the vadose zone, then the additional decay that occurs in the aquifer is minor. Low decay rates, i.e., long half-lives, have little impact on results.

\subsection{Retardation in the Aquifer}

Travel through the aquifer is primarily through the sediments. Consequently, attenuation of concentration peaks during travel through the aquifer generally will be the least for radionuclides with the lowest $K_{d}$ values for the sediments. Table 4.4-9 showed the contaminants with the lowest soil $\mathrm{K}_{\mathrm{d}}$ 's. Table 4.4-11 includes the radionuclides from Table 4.4-9, the soil distribution factor, the soil retardation factor, the water velocity, the contaminant velocity, and the approximate travel time through the aquifer.

\begin{tabular}{|l|c|c|c|c|c|c|}
\hline & Toil Distribution & Soil & Water & Contaminant & Travel Time to & PORFLOW \\
\hline & Coefficient $\left(\mathrm{K}_{\mathrm{d}}\right)$ & Retardation & Velocity & Velocity & 100 -m Well & Difference in Peaks \\
\hline & $(\mathrm{m} / \mathrm{g})$ & Factor $\left(\mathrm{R}_{\mathrm{d}}\right)$ & $(\mathrm{ft} / \mathrm{yr})$ & $(\mathrm{ft} / \mathrm{yr})$ & (yr) & (yr) \\
\hline Radionuclide & $\mathbf{0 . 1}$ & 1.80 & 45 & 25.07 & 13.09 & 5 \\
\hline $\mathrm{Tc}-99$ & 1.0 & 8.95 & 45 & 5.03 & 65.25 & 11 \\
\hline $\mathrm{I}-129$ & 1.7 & 14.52 & 45 & 3.10 & 105.83 & 15 \\
\hline $\mathrm{Cl}-36$ & 2.0 & 16.90 & 45 & 2.66 & 123.21 & 65 \\
\hline $\mathrm{Ca}-41$ & 5.0 & 40.75 & 45 & 1.10 & 297.10 & 99 \\
\hline $\mathrm{Mo}-93$ & 10.0 & 80.50 & 45 & 0.56 & 586.91 & 213 \\
\hline $\mathrm{K}-40$ & 15.0 & 120.25 & 45 & 0.37 & 876.71 & 105 \\
\hline $\mathrm{Si}-32$ & 35.0 & 279.25 & 45 & 0.16 & 2035.94 & 465 \\
\hline $\mathrm{Mn}-53$ & 50.0 & 398.50 & 45 & 0.11 & 2905.37 & 525 \\
\hline
\end{tabular}


A high retardation factor in the sediments reduces the peak concentration in two ways. First, the sediments hold more contamination, allowing the remainder in the water to attain only a relatively low concentration, similar to a slow release rate. Second, the sediments delay the contaminants, so that decay has longer to work. The approximate travel times are theoretical estimates that do not account for decay or varying concentrations at the source node.

\subsection{Normalized Concentration Plots}

Normalized concentration plots for each radionuclide are discussed below. First, the plot for Be-10 is discussed. Then, Table 4.4-12, providing a list of all peak times and peak fractional fluxes sorted by the peak magnitude is discussed. Values from Table 4.4-10 are plotted in Figure 4.4.12 and some apparent anomalies are highlighted. Then, the normalized concentration plots for each remaining radionuclide are described briefly.

The normalized concentration at the $100-\mathrm{m}$ down-gradient well is plotted in Figure 4.4 .10 in units of pCi/L per unit Curie of inventory. Similar to the fractional flux to the water table shown in that figure, the normalized concentration rises rapidly initially. The rapid rise continues until about the year 10,000 . A medium rate of rise occurs until about the year 18,000. After that, the rise is slow until the peak occurs at 24,680 years at a value of $0.95 \mathrm{pCi} / \mathrm{L}$ per $\mathrm{Ci}$. After the peak, the rate of decrease is low.

This behavior compares to a rapid rise in the fractional flux to the water table until the year 2,000 followed by a medium rate of rise until the year 10,000 , then a slow rise until the peak at 19,815 years. The peak at the 100 -m well occurs about 5,000 years after the peak flux at the water table. The travel time is caused by the high soil $K_{d}$ of $250 \mathrm{ml} / \mathrm{g}$.

The normalized peak concentration information, sorted by the magnitude of the peak concentration is provided for all the radionuclides in Table 4.4-12. Table 4.4-12 also includes fractional peak flux to the water table information with rankings.

Table 4.4-12 primarily echoes Table 4.4-10 with I-129 heading the list and Ho-166m trailing. The top six radionuclides again are the only contaminants with a peak normalized concentration that is within one order of magnitude of the leader, I-129.

In the top ten positions, the only change is that Be-10 has fallen from the seventh position to the ninth position, dropping below Mn-53 and Fe-60. Both Be-10 and Mn-53 had essentially the same peak fractional flux to the water, so Be-10's soil $\mathrm{K}_{d}$ of $250 \mathrm{mV} / \mathrm{g}$ caused the order switching, because $\mathrm{Mn}-53$ has a much lower soil $\mathrm{K}_{d}$ of 50 $\mathrm{ml} / \mathrm{g}$. Be-10 has a higher peak fraction flux to the water table than Fe-60 by almost a factor of two, 2.9E-5 vs. 1.7E5 . However, Be-10's soil $\mathrm{K}_{\mathrm{d}}$ is greater than Fe-60's of $220 \mathrm{mV} / \mathrm{g}$ that causes the order switching.

The only other change is that $\mathrm{C}-14$ and $\mathrm{Si}-32$ switched positions. Si-32 had a fractional flux to the water table that exceeded C-14's by a factor of two, 8.0E-8 vs. 3.2E-8. However, Si-32's short half-life of 330 years combined with a soil $\mathrm{K}_{\mathrm{d}}$ of $35 \mathrm{ml} / \mathrm{g}$ caused enough attenuation vs. C-14 with a 5,730 half-life and a soil $\mathrm{K}_{\mathrm{d}}$ of $2 \mathrm{ml} / \mathrm{g}$ that the switch occurred.

Figure 4.4.12 shows the results for $\mathrm{C}-14$. The relatively low peak concentration of $2.2 \mathrm{E}-3 \mathrm{pCi} / \mathrm{L} / \mathrm{Ci}$ occurs at 14,280 years, about 65 years after the peak fractional flux to the water table occurs. The concentration decreases at a medium rate after the peak, because of the low soil $\mathrm{K}_{d}$ of $2 \mathrm{ml} / \mathrm{g}$. The peak concentration during the first 10,000 years is $1.3 \mathrm{E}-3 \mathrm{pCi} / \mathrm{L} / \mathrm{Ci}$.

Figure 4.4.13 shows the results for Al-26. The peak concentration of $0.25 \mathrm{pCi} / \mathrm{L} / \mathrm{Ci}$ occurs at 151,500 years, about 27,000 years after the peak fractional flux to the water table occurs. The concentration decreases at a slow rate after the peak, because of the high soil $\mathrm{K}_{\mathrm{d}}$ of $1,500 \mathrm{ml} / \mathrm{g}$. The peak concentration during the first 10,000 years is $1.4 \mathrm{E}-8$ $\mathrm{pCi} / \mathrm{L} / \mathrm{Ci}$.

Figure 4.4.14 shows the results for Si-32. The relatively low peak concentration of $1.7 \mathrm{E}-3 \mathrm{pCi} / \mathrm{L} / \mathrm{Ci}$ occurs at 3,150 years, about 400 years after the peak fractional flux to the water table occurs. The peak is sharper than the peaks for the other radionuclides, due to the relatively short half-life of 330 years. 


\section{Table 4.4-12. Peak Fractional Fluxes and Normalized Concentrations versus Time}

\begin{tabular}{|c|c|c|c|c|c|c|}
\hline \multirow{2}{*}{ Radionuclide } & \multicolumn{2}{|c|}{$\begin{array}{l}\text { Peak Fractional Flux to Water } \\
\text { Table }\end{array}$} & \multicolumn{2}{|c|}{$\begin{array}{l}\text { Normalized Peak } \\
\text { Concentration }\end{array}$} & \multirow{2}{*}{$\begin{array}{l}\begin{array}{l}\text { Normalized } \\
\text { Concentration at } \\
10,000 \text { Years }\end{array} \\
\text { Magnitude } \\
\text { (pCi/L per } 1 \mathrm{Ci} \\
\text { of Inventory) } \\
\end{array}$} & \multirow[t]{2}{*}{$\begin{array}{l}\text { Rank } \\
\text { WT } \\
\text { Flux } \\
\end{array}$} \\
\hline & $\begin{array}{l}\text { Magnitude } \\
\text { (Ci per } 1 \mathrm{Ci} \text { of } \\
\text { Inventory) }\end{array}$ & $\begin{array}{l}\text { Time } \\
\text { (years) }\end{array}$ & $\begin{array}{l}\text { Magnitude } \\
\text { (pCi/L per I Ci } \\
\text { of Inventory) }\end{array}$ & $\begin{array}{l}\text { Time } \\
\text { (years) }\end{array}$ & & \\
\hline $1-129$ & $3.9 \mathrm{E}-4$ & 1,051 & 25 & 1,062 & & 1 \\
\hline $\mathrm{Ca}-41$ & $2.7 \mathrm{E}-4$ & 1,721 & 18 & 1,820 & & 2 \\
\hline $\mathrm{K}-40$ & $2.0 \mathrm{E}-4$ & 4,465 & 14 & 4,570 & & 3 \\
\hline $\mathrm{Cl}-36$ & $1.6 \mathrm{E}-4$ & 4,495 & 11 & 4,510 & & 4 \\
\hline Mo-93 & $1.6 \mathrm{E}-4$ & 1,897 & 9.8 & 2,110 & & 5 \\
\hline $\mathrm{Se}-79$ & $4.2 \mathrm{E}-5$ & 12,715 & 2.6 & 15,970 & 0.96 & 6 \\
\hline $\mathrm{Mn}-53$ & $2.9 \mathrm{E}-5$ & 17,415 & 2.0 & 17,940 & 1.2 & 8 \\
\hline $\mathrm{Fe}-60$ & $1.7 \mathrm{E}-5$ & 32,486 & 1.1 & 36,950 & $1.1 \mathrm{E}-2$ & 9 \\
\hline $\mathrm{Be}-10$ & $2.9 \mathrm{E}-5$ & 19,815 & 0.95 & 24,680 & 0.031 & 7 \\
\hline $\mathrm{Ni}-59$ & $8.8 \mathrm{E}-6$ & 44,245 & 0.53 & 50,770 & $8.6 \mathrm{E}-4$ & 10 \\
\hline $\mathrm{Pb}-205$ & $5.8 \mathrm{E}-6$ & 79,720 & 0.39 & 82,070 & $1.5 \mathrm{E}-4$ & 11 \\
\hline $\mathrm{Pb}-202$ & $4.9 \mathrm{E}-6$ & 69,545 & 0.33 & 75,260 & $1.4 \mathrm{E}-4$ & 12 \\
\hline Al-26 & $4.1 E-6$ & 124,180 & 0.25 & 151,500 & $1.4 \mathrm{E}-8$ & 13 \\
\hline Tc-99 & $3.1 \mathrm{E}-6$ & 41,845 & 0.21 & 41,850 & 0.15 & 14 \\
\hline $\mathrm{Nb}-94$ & $1.8 \mathrm{E}-6$ & 27,430 & 0.11 & 31,062 & $2.5 \mathrm{E}-3$ & 15 \\
\hline Sm-146 & $7.2 \mathrm{E}-7$ & 407,300 & 0.049 & 410,180 & $2.1 \mathrm{E}-8$ & 16 \\
\hline Hf- 182 & $6.9 \mathrm{E}-7$ & 423,000 & 0.044 & 434,500 & $2.2 \mathrm{E}-11$ & 17 \\
\hline Zr-93 & $5.8 \mathrm{E}-7$ & 336,300 & 0.039 & 351,820 & $1.2 \mathrm{E}-12$ & 18 \\
\hline La-137 & $3.1 \mathrm{E}-7$ & 127,000 & 0.02 & 149,000 & $6.7 \mathrm{E}-11$ & 19 \\
\hline $\mathrm{C}-14$ & $3.2 \mathrm{E}-8$ & 14,215 & 0.0022 & 14,280 & $1.3 \mathrm{E}-3$ & 21 \\
\hline Si-32 & 8.0E-8 & 2,685 & 0.0017 & 3,150 & & 20 \\
\hline Tb-158 & $4.1 \mathrm{E}-10$ & 10,715 & 0.0000045 & 12,640 & $3.2 \mathrm{E}-6$ & 22 \\
\hline Ho- $166 \mathrm{~m}$ & $4.2 \mathrm{E}-13$ & 16,900 & $4.3 \mathrm{E}-9$ & 19,160 & $5.7 \mathrm{E}-11$ & 23 \\
\hline
\end{tabular}

Figure 4.4.15 shows the results for $\mathrm{Cl}-36$. The relatively high peak of $11 \mathrm{pCi} / \mathrm{L} / \mathrm{Ci}$ occurs at 4,510 years, about 15 years after the peak fractional flux to the water table occurs. The peak decreases at a moderate rate after the peak, because of the soil $\mathrm{K}_{\mathrm{d}}$ of $1.7 \mathrm{ml} / \mathrm{g}$ combined with new contamination emerging from the vault with a Kd of $20 \mathrm{ml} / \mathrm{g}$. This type of behavior occurs for most contaminants that have a higher $K_{d}$ in the concrete vault than in the sediments. The concrete vault continues to provide contamination at a fairly constant rate for a long time period. Once contamination exits the vault, it moves more quickly to the well establishing a dynamic state of equilibrium where the rate of change in the well concentration is low for a long duration.

Figure 4.4.16 shows the results for $\mathrm{K}-40$. The relatively high peak of $14 \mathrm{pCi} / \mathrm{L} / \mathrm{Ci}$ occurs at 4,570 years about 100 years after the peak fractional flux to the water table.

Figure 4.4.17 shows the results for $\mathrm{Ca}-41$. The relatively high peak of $18 \mathrm{pCi} / \mathrm{L} / \mathrm{Ci}$ occurs at 1,820 years about 100 years after the peak fractional flux to the water table.

Figure 4.4.18 shows the results for $\mathrm{Mn}-53$. The peak of $2.0 \mathrm{pCi} / \mathrm{L} / \mathrm{Ci}$ occurs at 17,940 years, about 500 years after the peak fractional flux to the water table.

Figure 4.4.19 shows the results for $\mathrm{Ni}-59$. The peak of $0.53 \mathrm{pCi} / \mathrm{L} / \mathrm{Ci}$ occurs at 50,770 years, about 6,000 years after the peak fractional flux to the water table.

Figure 4.4.20 shows the results for $\mathrm{Fe}-60$. The peak of $1.1 \mathrm{pCi} / \mathrm{L} / \mathrm{Ci}$ occurs at 36,950 years, about 4,500 years after the peak fractional flux to the water table. 
Figure 4.4.21 shows the results for Se-79. The relatively high peak of $2.6 \mathrm{pCi} / \mathrm{L} / \mathrm{Ci}$ occurs at 15,970 years, about 3,000 years after the peak fractional flux to the water table.

Figure 4.4.22 shows the results for Mo-93. The relatively high peak of $9.8 \mathrm{pCi} / \mathrm{L} / \mathrm{Ci}$ occurs at 2,110 years, about 200 years after the peak fractional flux to the water table.

Figure 4.4.23 shows the results for $\mathrm{Nb}-94$. The peak of $0.11 \mathrm{pCi} / \mathrm{L} / \mathrm{Ci}$ occurs at 31,100 years, about 3,500 years after the peak fractional flux to the water table.

Figure 4.4.24 shows the results for $\mathrm{Zr}-93$. The relatively low peak of $3.9 \mathrm{E}-2 \mathrm{pCi} / \mathrm{L} / \mathrm{Ci}$ occurs at 351,820 years, about 15,000 years after the peak fractional flux to the water table, because of its high soil $\mathrm{K}_{d}$ of $600 \mathrm{ml} / \mathrm{g}$.

Figure 4.4.25 shows the results for Tc-99. The peak of $0.21 \mathrm{pCi} / \mathrm{L} / \mathrm{Ci}$ occurs at 41,850 years, about 5 years after the peak fractional flux to the water table. The quick aquifer travel time is caused by the very low soil $\mathrm{K}_{d}$ of $0.1 \mathrm{~m} / \mathrm{g}$. The peak time at the water table is caused by the high concrete $\mathrm{K}_{\mathrm{d}}$ of $1,000 \mathrm{ml} / \mathrm{g}$.

Figure 4.4.26 shows the results for $\mathrm{I}-129$. The peak of $25 \mathrm{pCi} / \mathrm{L} / \mathrm{Ci}$ is the highest among all the radionuclides analyzed and occurs at the earliest time - 1,062 years, about 11 years after the peak fractional flux to the water table. These results are caused by the low concrete $K_{d}$ of $2 \mathrm{mV} / \mathrm{g}$ accompanied by the low soil $\mathrm{K}_{d}$ of $1 \mathrm{~m} / \mathrm{g}$. Shortly after 1,000 years, a spike in the contaminant concentration mimics a spike in the water table flux curve.

Figure 4.4.27 shows the results for La-137. The relatively low peak of 2.0E-2 pCi/L/Ci occurs at 149,000 years, about 22,000 years after the peak fractional flux to the water table. The slow travel through the aquifer is caused by a high soil $\mathrm{K}_{\mathrm{d}}$ of $1,200 \mathrm{ml} / \mathrm{g}$.

Figure 4.4.28 shows the results for Sm-146. The relatively low peak of 4.9E-2 pCi/L/Ci occurs at 410,200 years, about 3,000 years after the peak fractional flux to the water table. $\mathrm{Sm}-146$ has a soil $\mathrm{K}_{4}$ that is more than one order of magnitude less than the concrete $K_{d}(245 \mathrm{ml} / \mathrm{g}$ vs. $5,000 \mathrm{ml} / \mathrm{g})$. This difference in $\mathrm{K}_{d}$ 's causes the very long time to peak at the water table, followed by the relatively shorter time to peak at the well.

Figure 4.4.29 shows the results for $\mathrm{Tb}-158$. The relatively low peak of $4.5 \mathrm{E}-6 \mathrm{pCi} / \mathrm{L} / \mathrm{Ci}$ occurs at 12,640 years, about 2,000 years after the peak fractional flux to the water table. Tb-158's short half-life of 1,200 years affects the peak time, because $\mathrm{Tb}-158$ has a high concrete $\mathrm{K}_{d}$ of $240 \mathrm{ml} / \mathrm{g}$ and a high soil $\mathrm{K}_{d}$ of $240 \mathrm{ml} / \mathrm{g}$.

Figure 4.4.30 shows the results for Ho-166m. The very low peak of $4.3 \mathrm{E}-9 \mathrm{pCi} / \mathrm{L} / \mathrm{Ci}$ occurs at 19,160 years, about 2,000 years after the peak fractional flux to the water table. Ho- $166 \mathrm{~m}$ 's short half-life of 1,200 years affects the peak time, because Ho-166m has a high concrete $\mathrm{K}_{\mathrm{d}}$ of $5,000 \mathrm{ml} / \mathrm{g}$ and a high soil $\mathrm{K}_{d}$ of $250 \mathrm{mV} / \mathrm{g}$.

Figure 4.4.31 shows the results for Hf-182. The relatively low peak of 4.4E-2 $\mathrm{pCi} / \mathrm{L} / \mathrm{Ci}$ occurs at 434,500 years, about 11,000 years after the peak fractional flux to the water table. Hf-182 has a soil $\mathrm{K}_{d}$ that is more than one order of magnitude less than the concrete $K_{d}(450 \mathrm{ml} / \mathrm{g}$ vs. $5,000 \mathrm{ml} / \mathrm{g})$. This difference in $\mathrm{K}_{d}$ 's causes the very long time to peak at the water table, followed by the relatively shorter time to peak at the well.

Figure 4.4.32 shows the results for $\mathrm{Pb}-202$. The peak of $0.33 \mathrm{pCi} / \mathrm{L} / \mathrm{Ci}$ occurs at 75,300 years, about 5,000 years after the peak fractional flux to the water table.

Figure 4.4.33 shows the results for $\mathrm{Pb}-205$. The peak of $0.39 \mathrm{pCi} / \mathrm{L} / \mathrm{Ci}$ occurs at 82,070 years, about 2,000 years after the peak fractionall flux to the water table. The difference between $\mathrm{Pb}-202$ and $\mathrm{Pb}-205$ is caused by the difference in the half-lives $(300,000$ years and $15,100,000$ years, respectively). The longer-lived $\mathrm{Pb}-205$ has a marginally higher peak that occurs slightly later.

\subsubsection{Fractional Flux and Normalized Concentration Figures}

The fractional flux and normalized concentration plots for all radionuclides, except for $\mathrm{Be}-10$ are presented in this section. The plot for $\mathrm{Be}-10$ was presented earlier. Discussion of each of these plots was provided in the results sections for the vadose zone and the aquifer. 


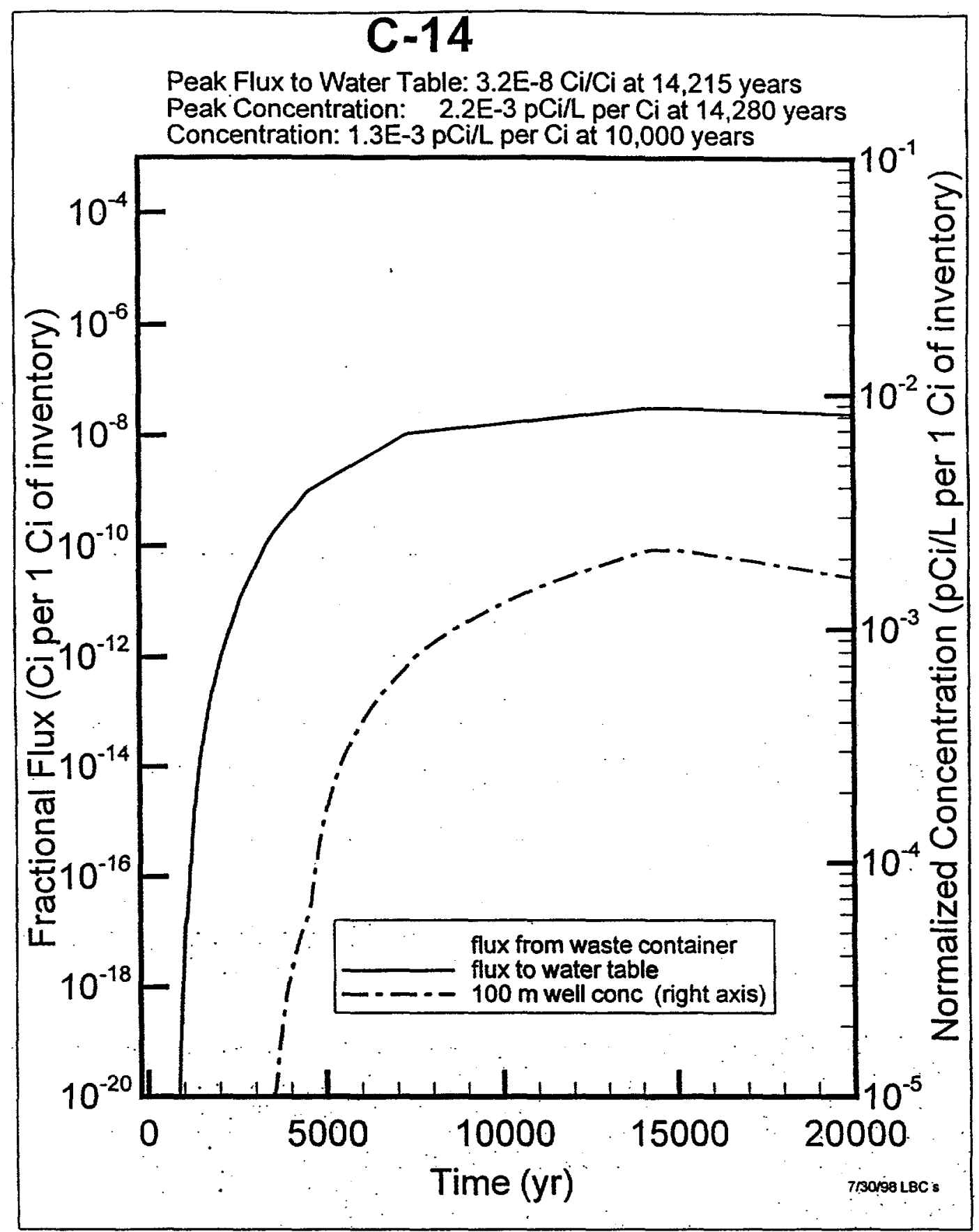

Figure 4.4.12. Flux and Concentration Results for C-14 


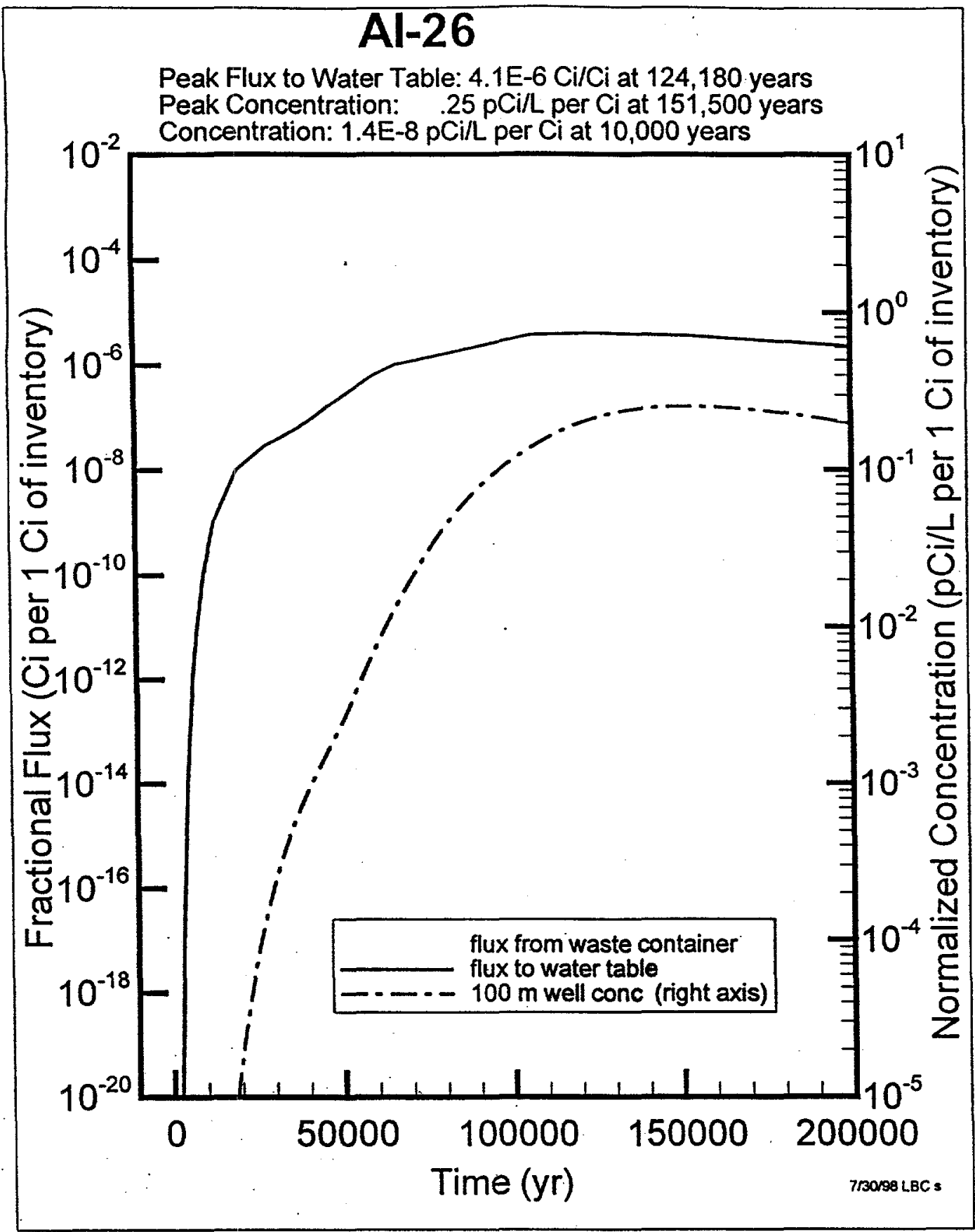

Figure 4.4.13. Flux and Concentration Results for Al-26 


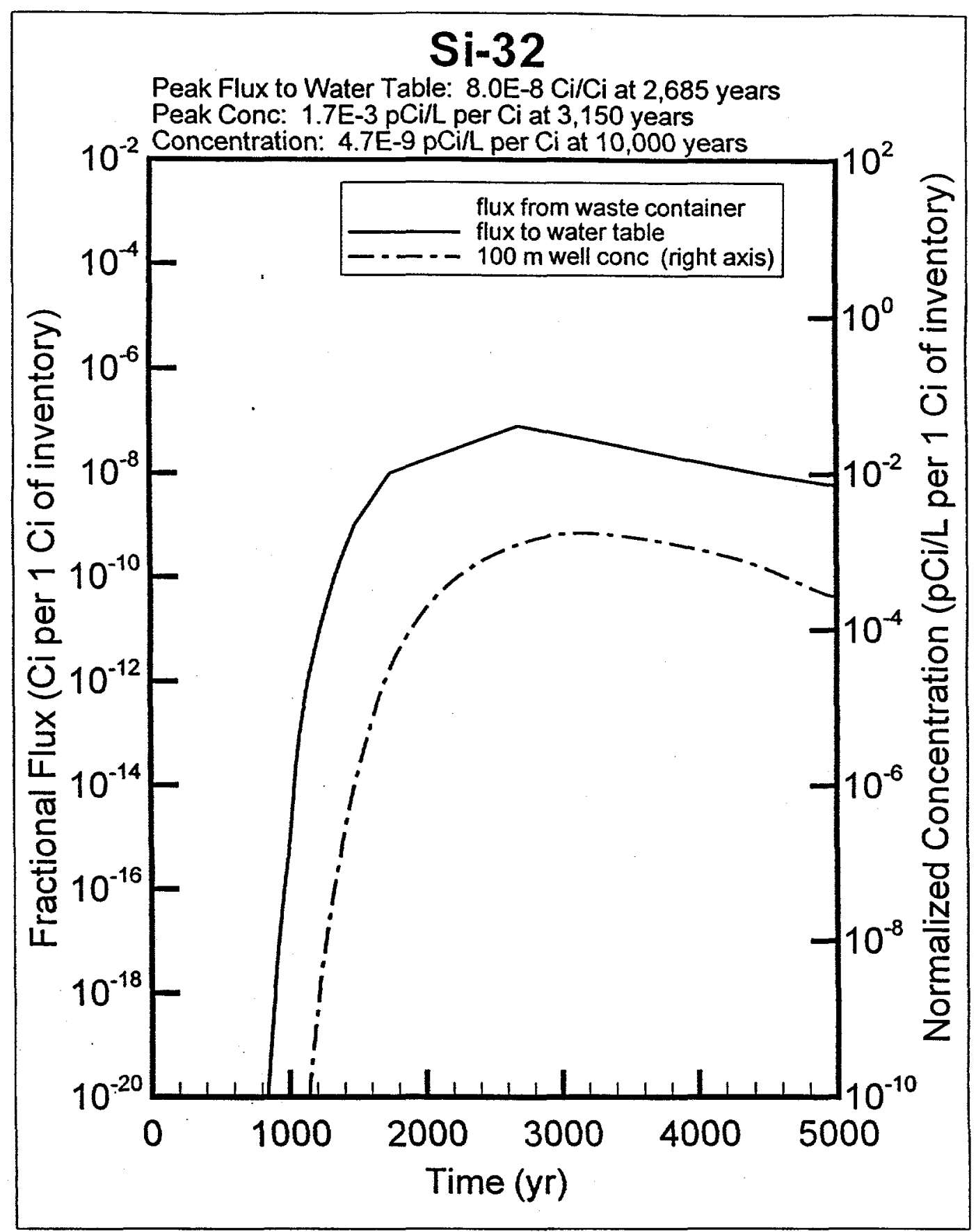

Figure 4.4.14. Flux and Concentration Results for Si-32 


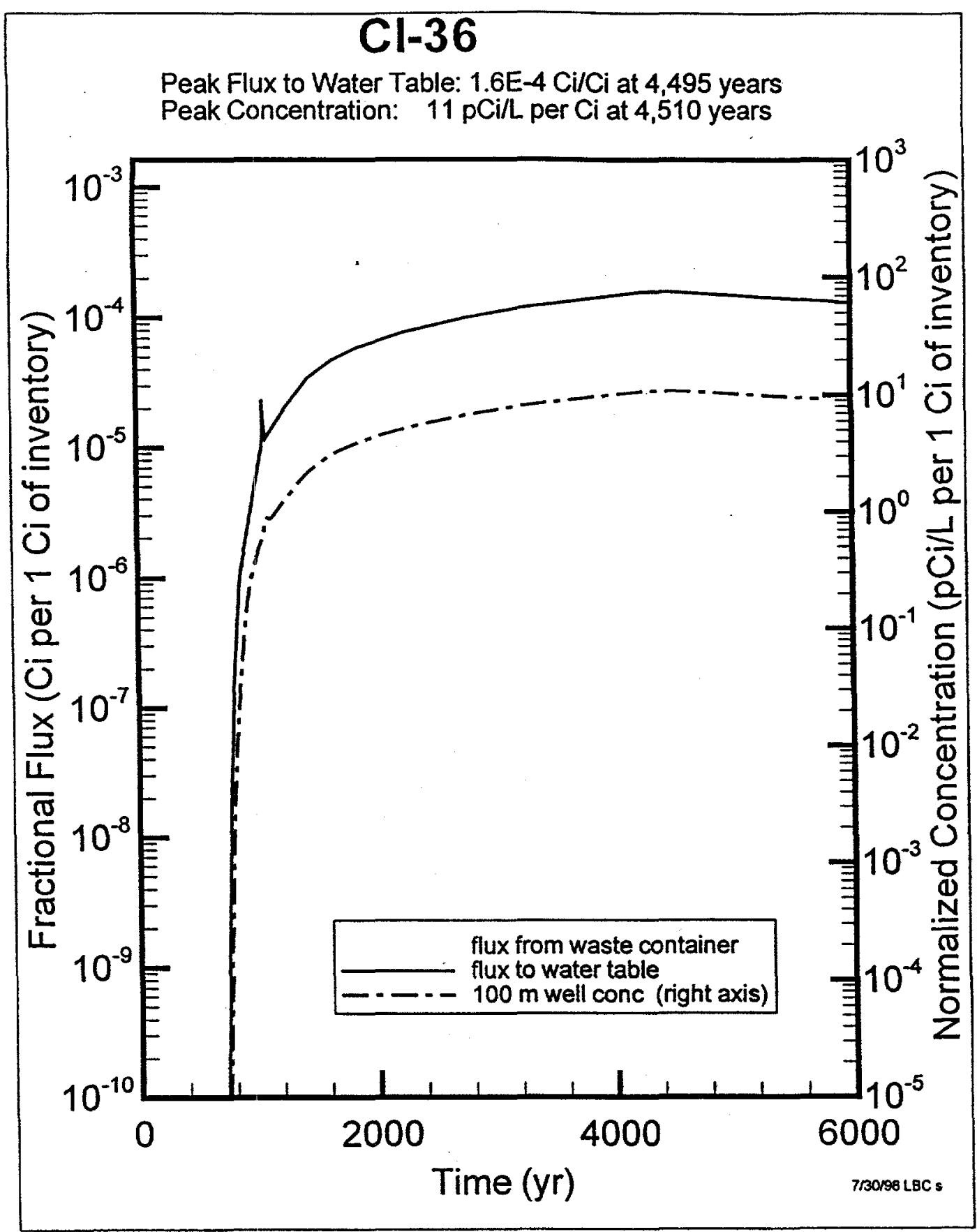

Figure 4.4.15. Flux and Concentration Results for $\mathrm{Cl}-36$ 


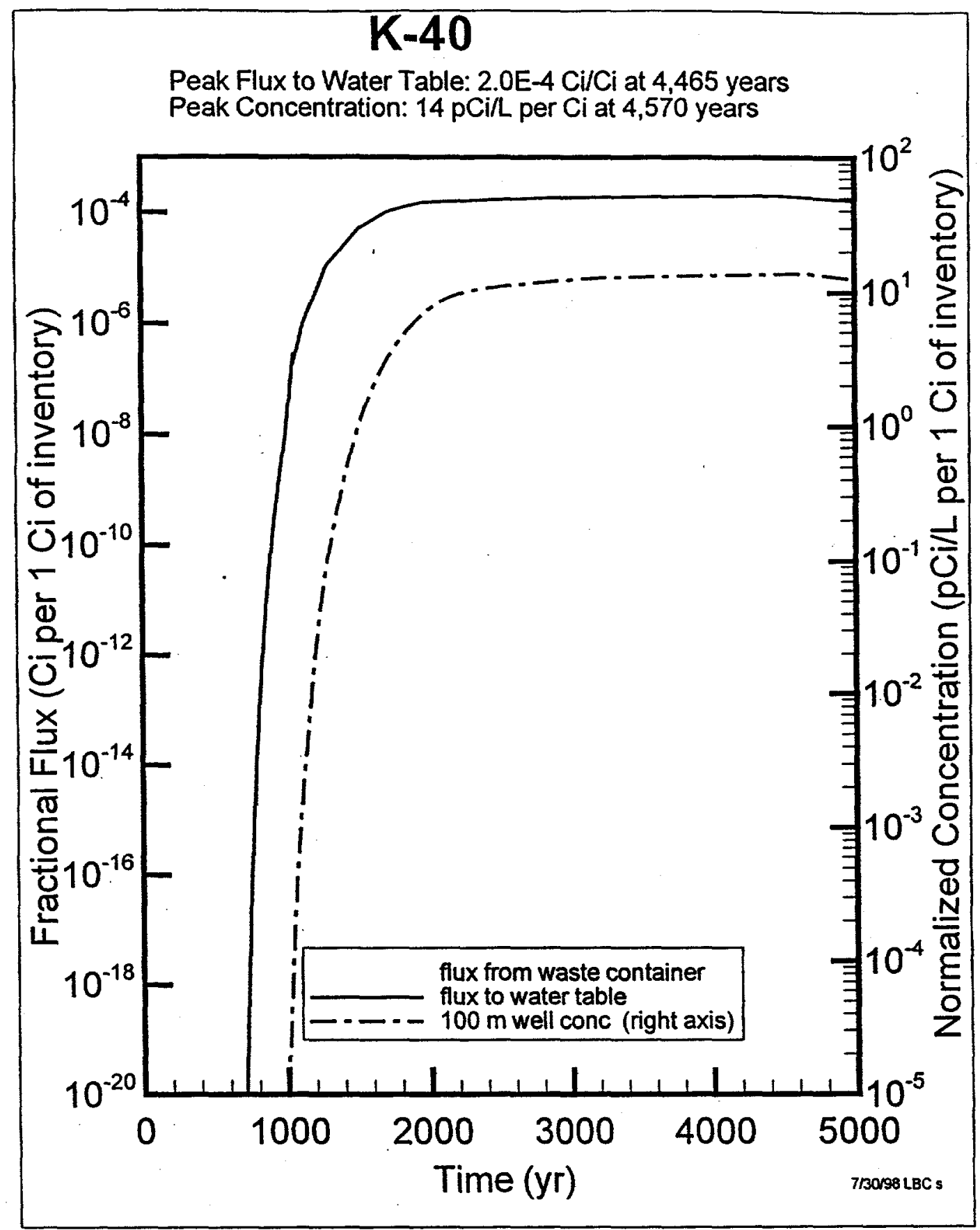

Figure 4.4.16. Flux and Concentration Results for $\mathrm{K}-40$ 


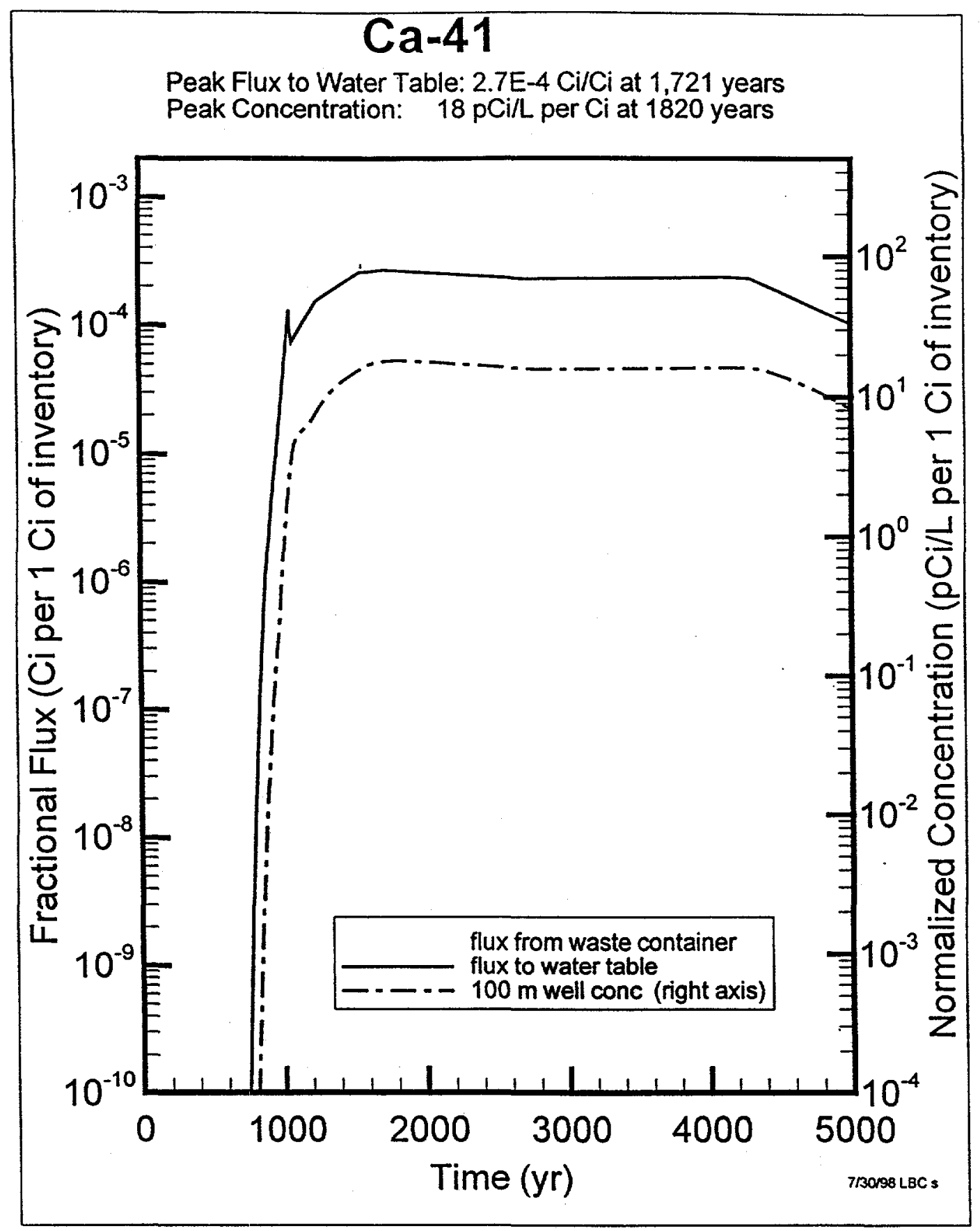

Figure 4.4.17. Flux and Concentration Results for Ca-41 


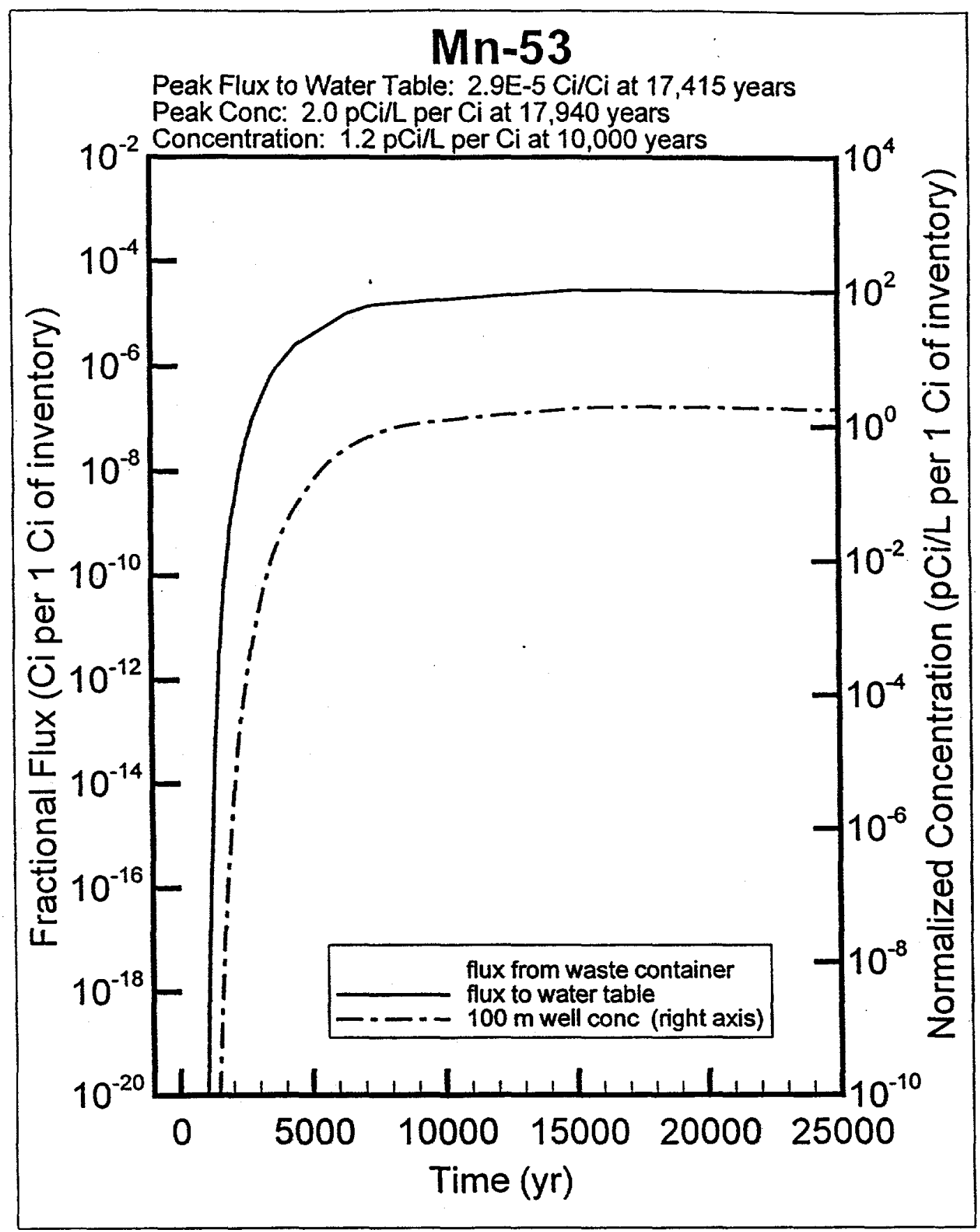

Figure 4.4.18. Flux and Concentration Results for Mn-53 


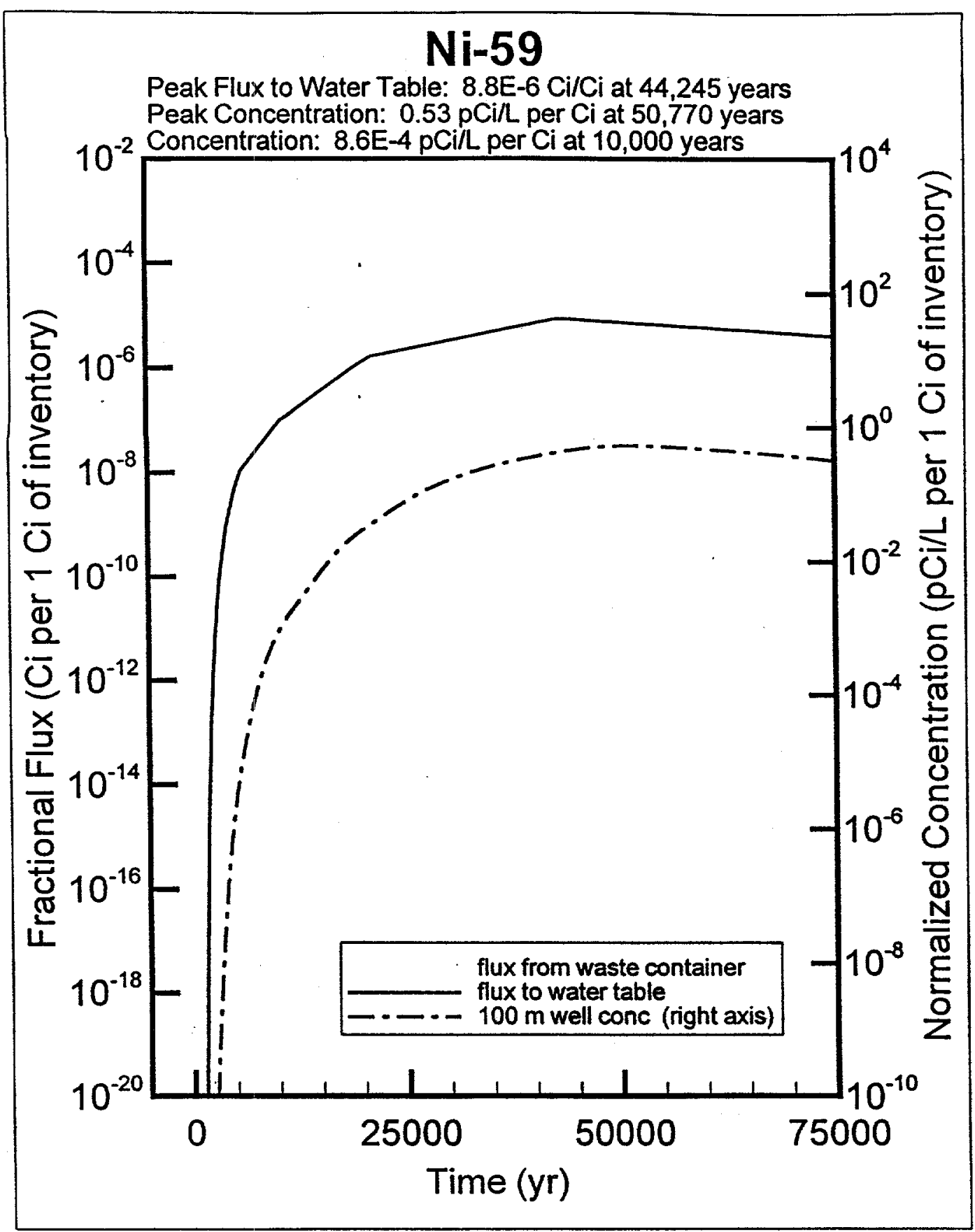

Figure 4.4.19. Flux and Concentration Results for Ni-59 


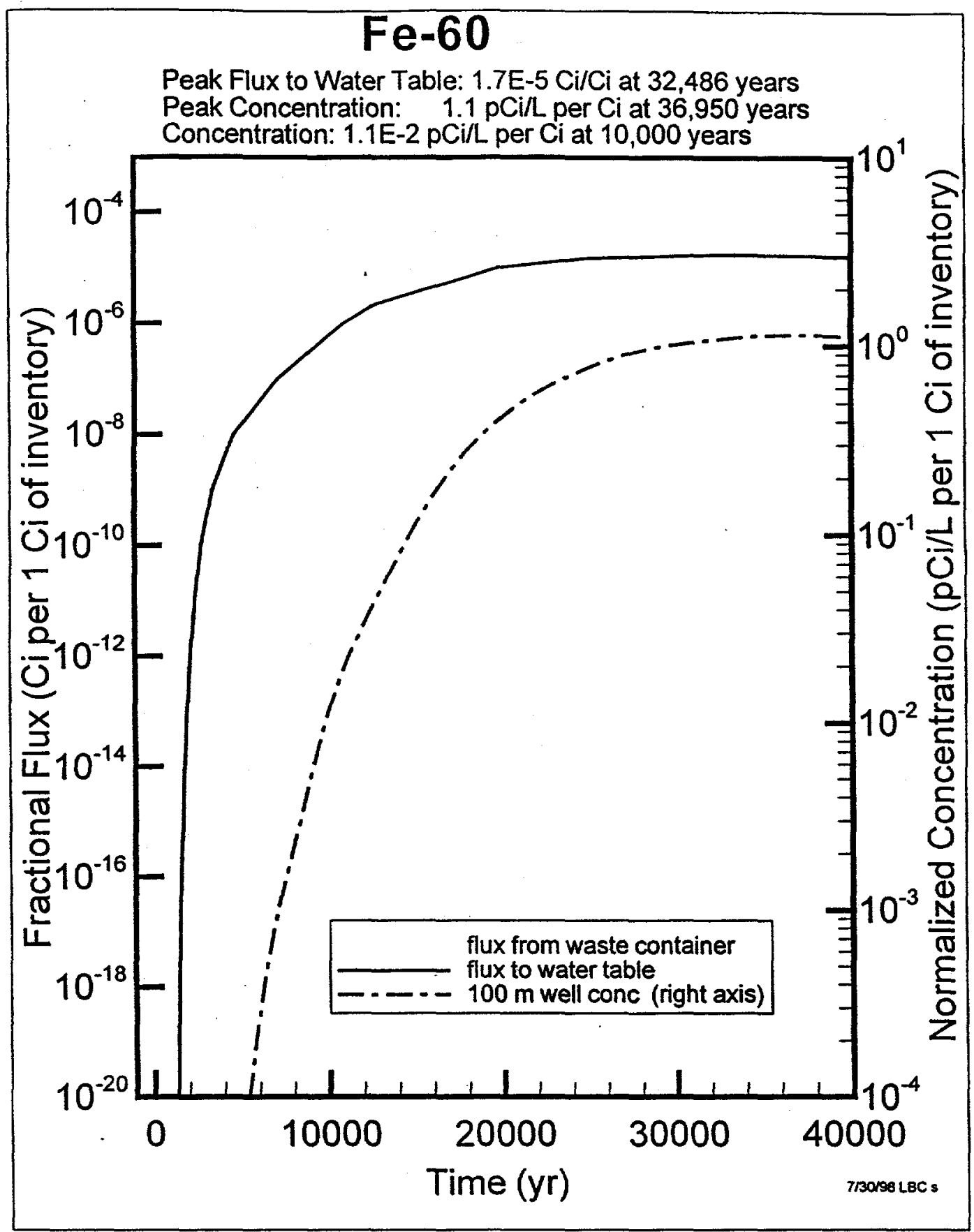

Figure 4.4.20. Flux and Concentration Results for Fe-60 


\section{Se-79}

Peak Flux to Water Table: $4.2 \mathrm{E}-5 \mathrm{Ci} / \mathrm{Ci}$ at 12,715 years

Peak Conc: $2.6 \mathrm{pCi} / \mathrm{L}$ per $\mathrm{Ci}$ at 15,970 years

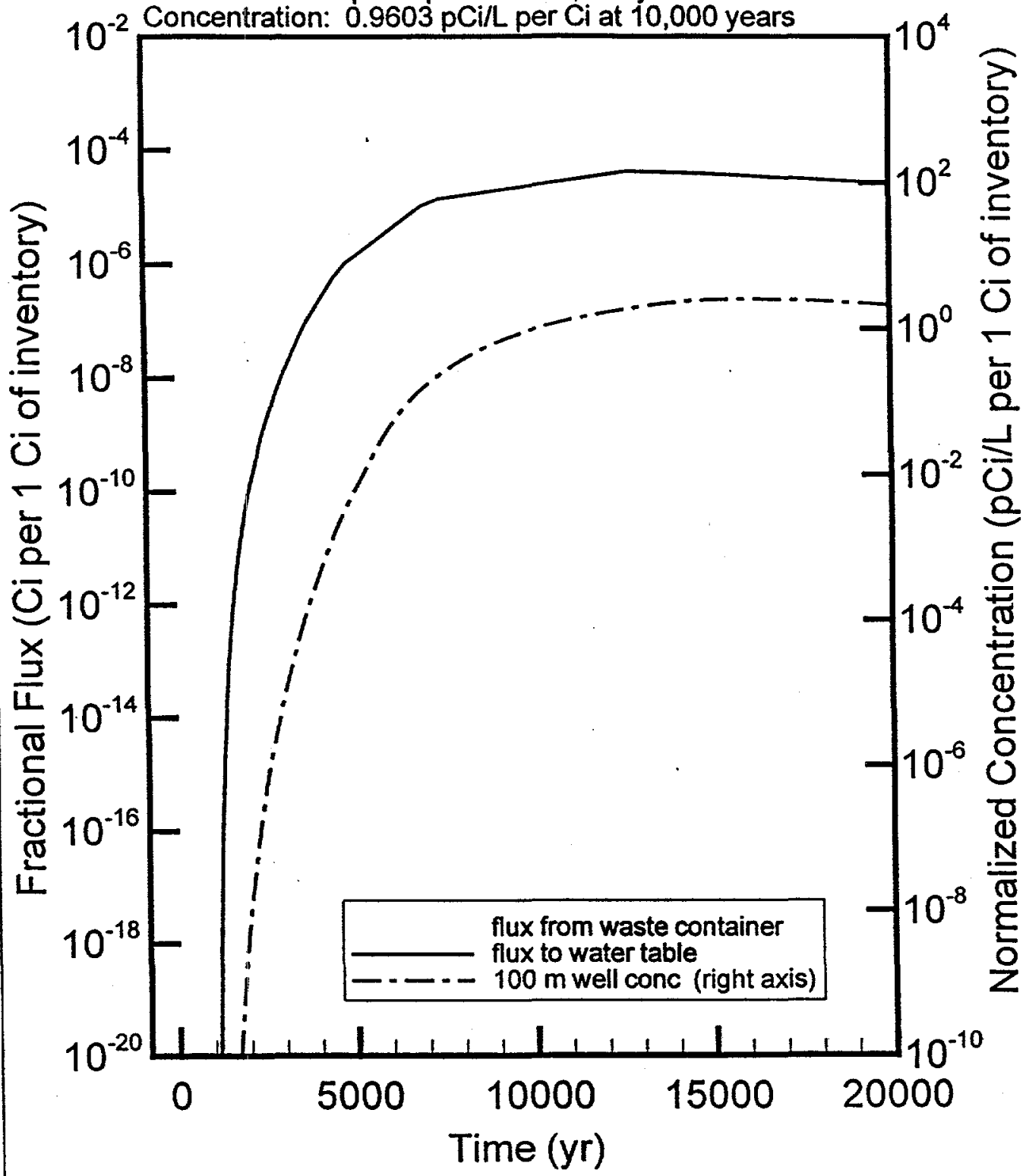

Figure 4.4.21. Flux and Concentration Results for Se-79 


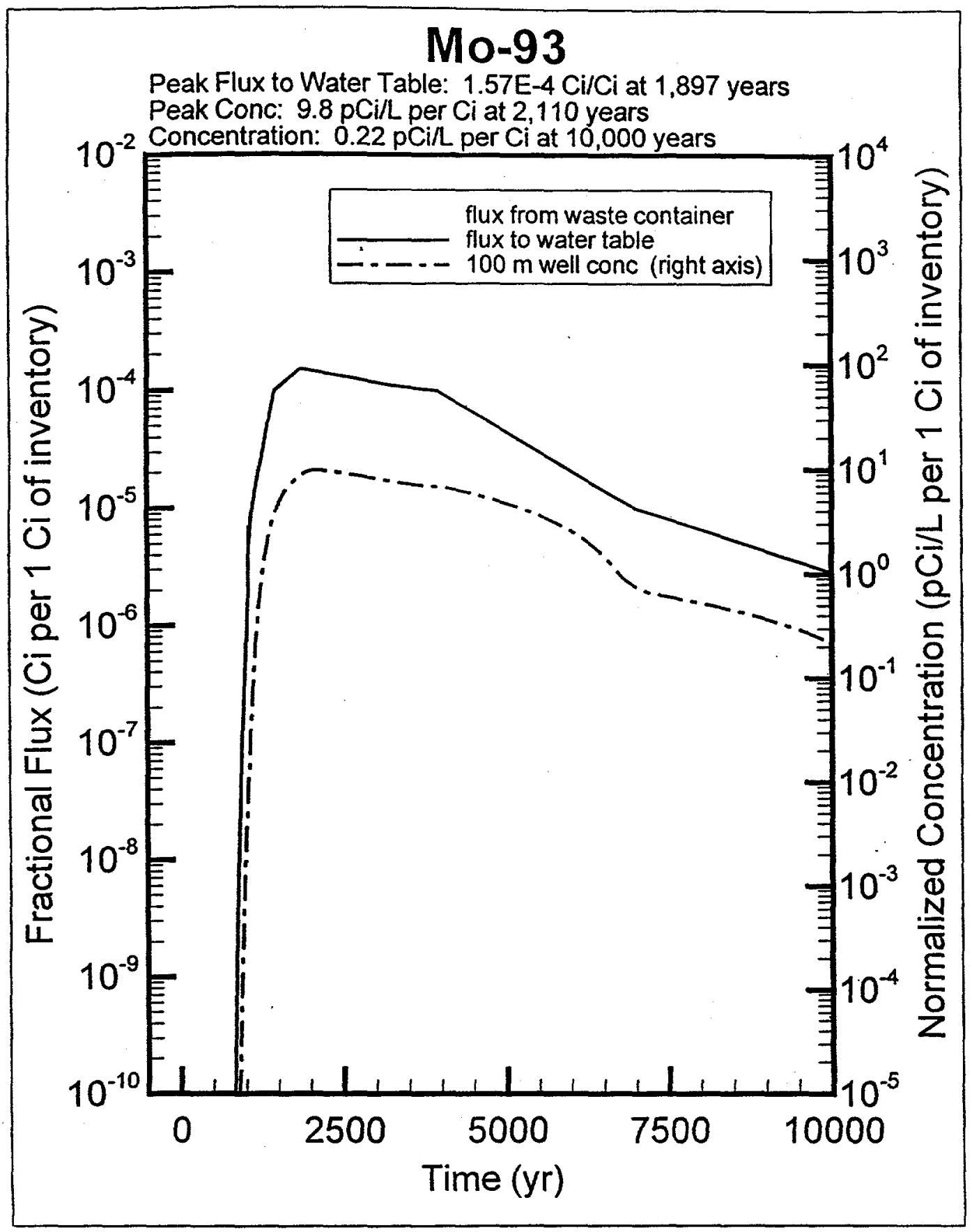

Figure 4.4.22. Flux and Concentration Results for Mo-93 


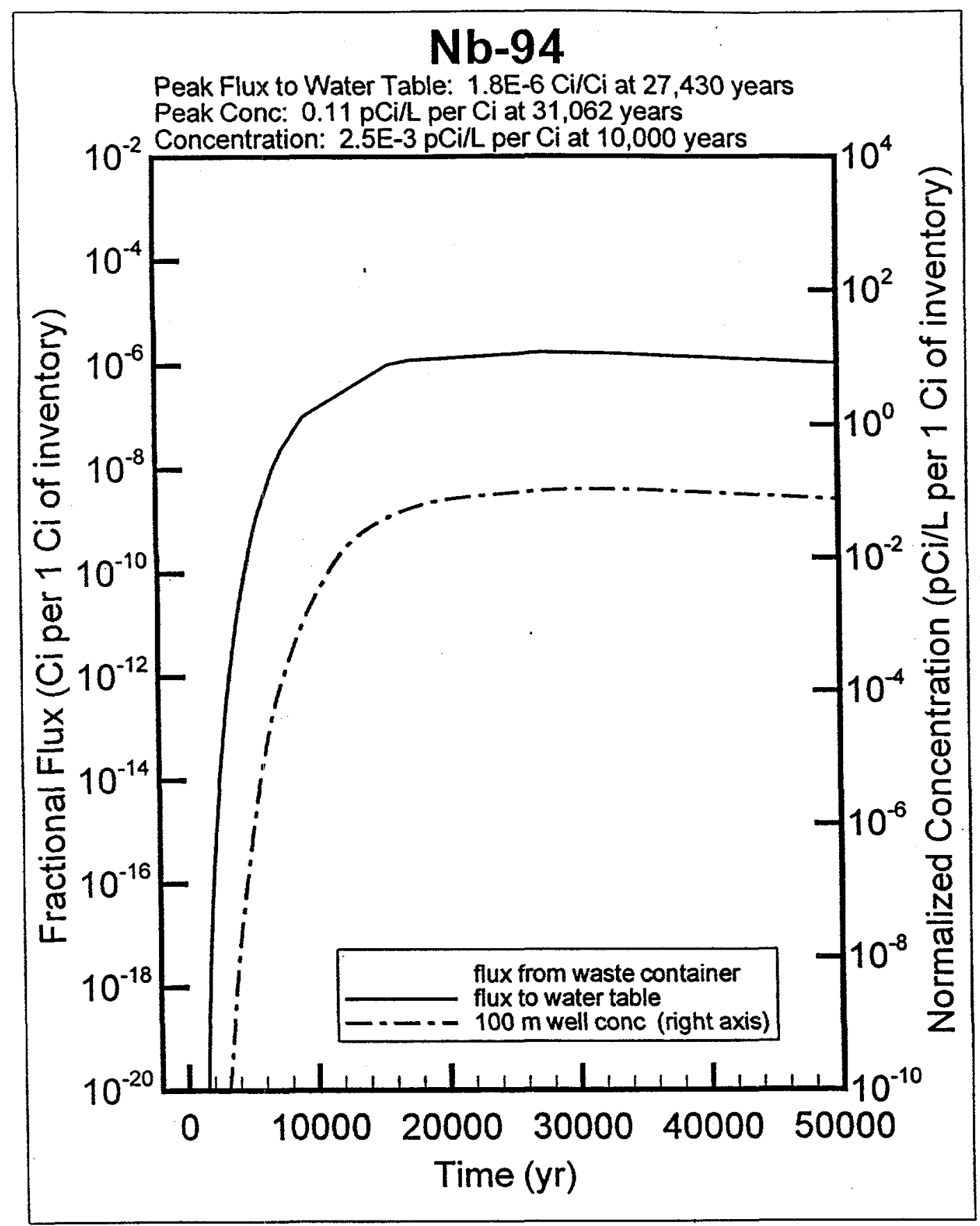

Figure 4.4.23. Flux and Concentration Results for Nb-94 


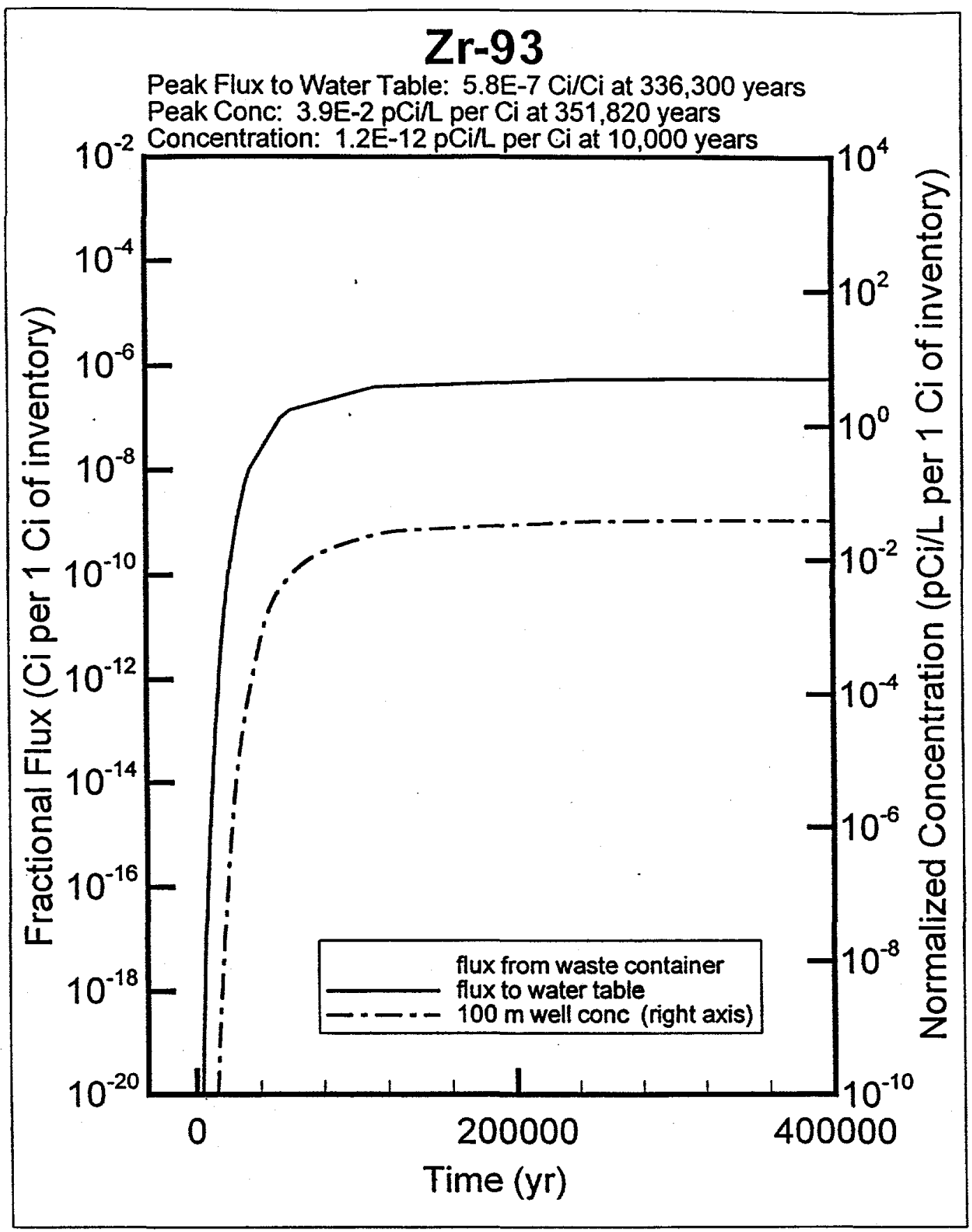

Figure 4.4.24. Flux and Concentration Results for Zr-93 


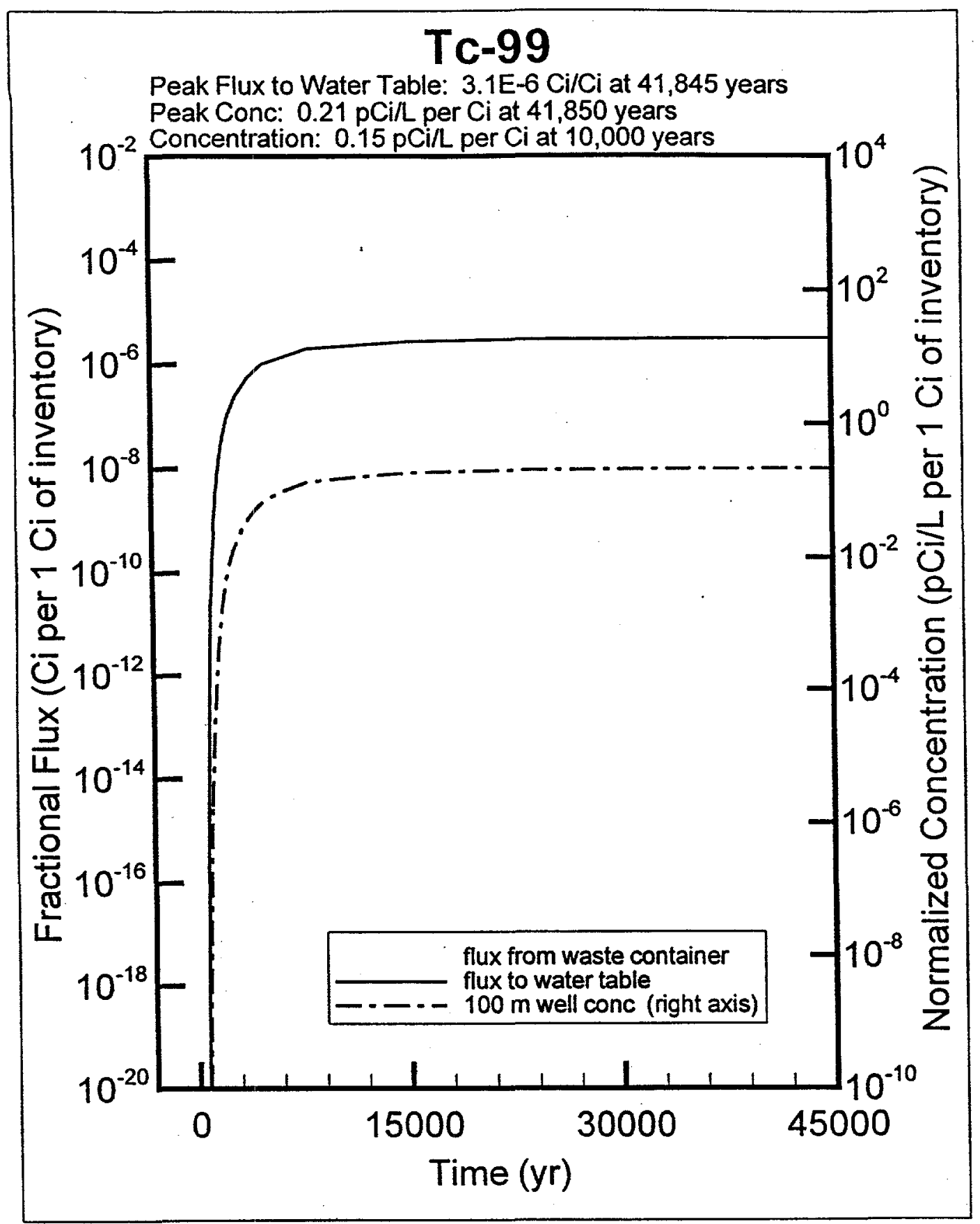

Figure 4.4.25. Flux and Concentration Results for Tc-99 


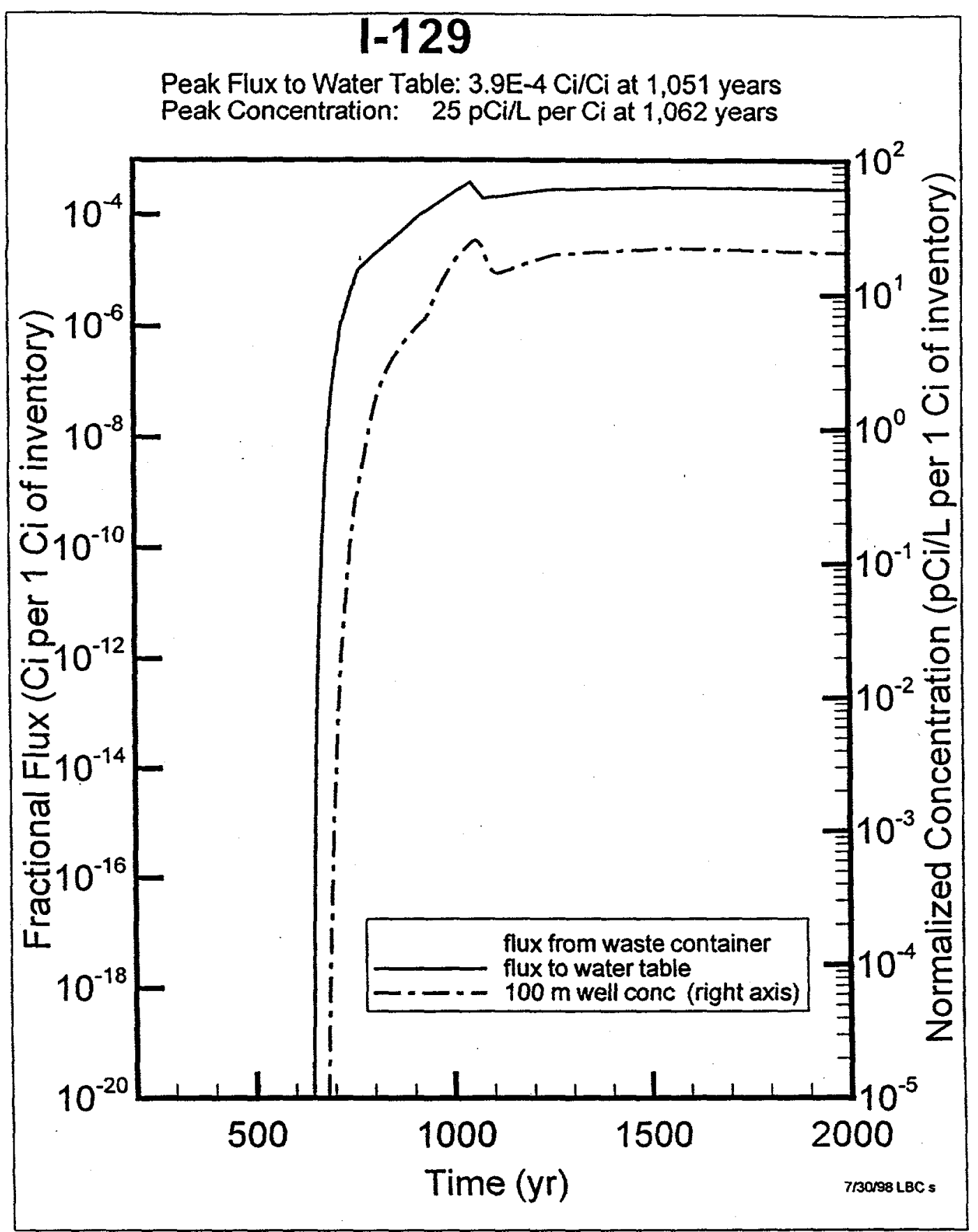

Figure 4.4.26. Flux and Concentration Results for I-129 


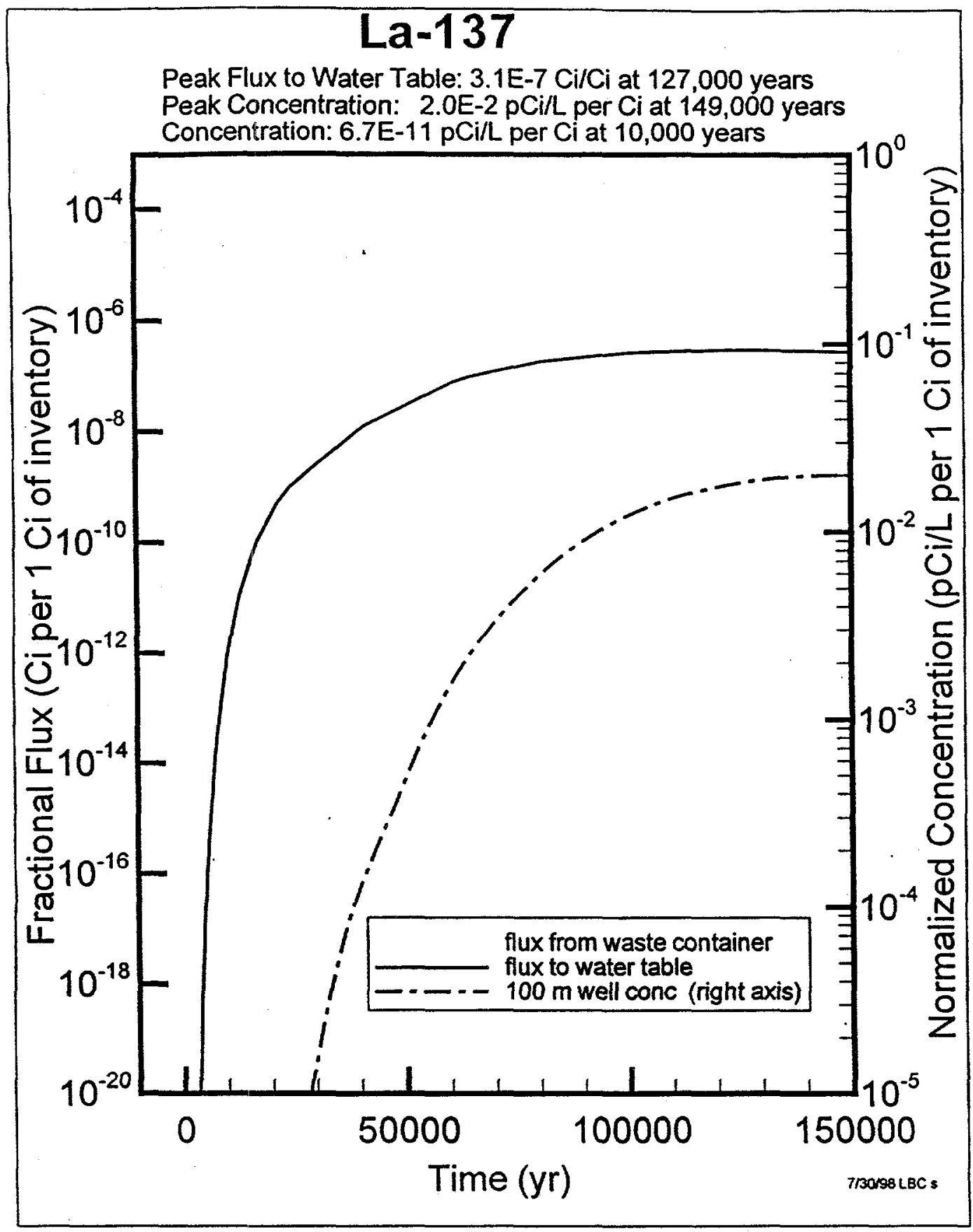

Figure 4.4.27. Flux and Concentration Results for La-137 


\section{$\mathrm{Sm}-146$}

Peak Flux to Water Table: $7.2 \mathrm{E}-7 \mathrm{Ci} / \mathrm{Ci}$ at 407,300 years

Peak Conc: $4.9 \mathrm{E}-2 \mathrm{pCi} / \mathrm{L}$ per $\mathrm{Ci}$ at 410,180 years

$10^{-2}$ Concentration: $2.1 \mathrm{E}-8 \mathrm{pCi} / \mathrm{L}$ per $\mathrm{Ci}$ at 10,000 years

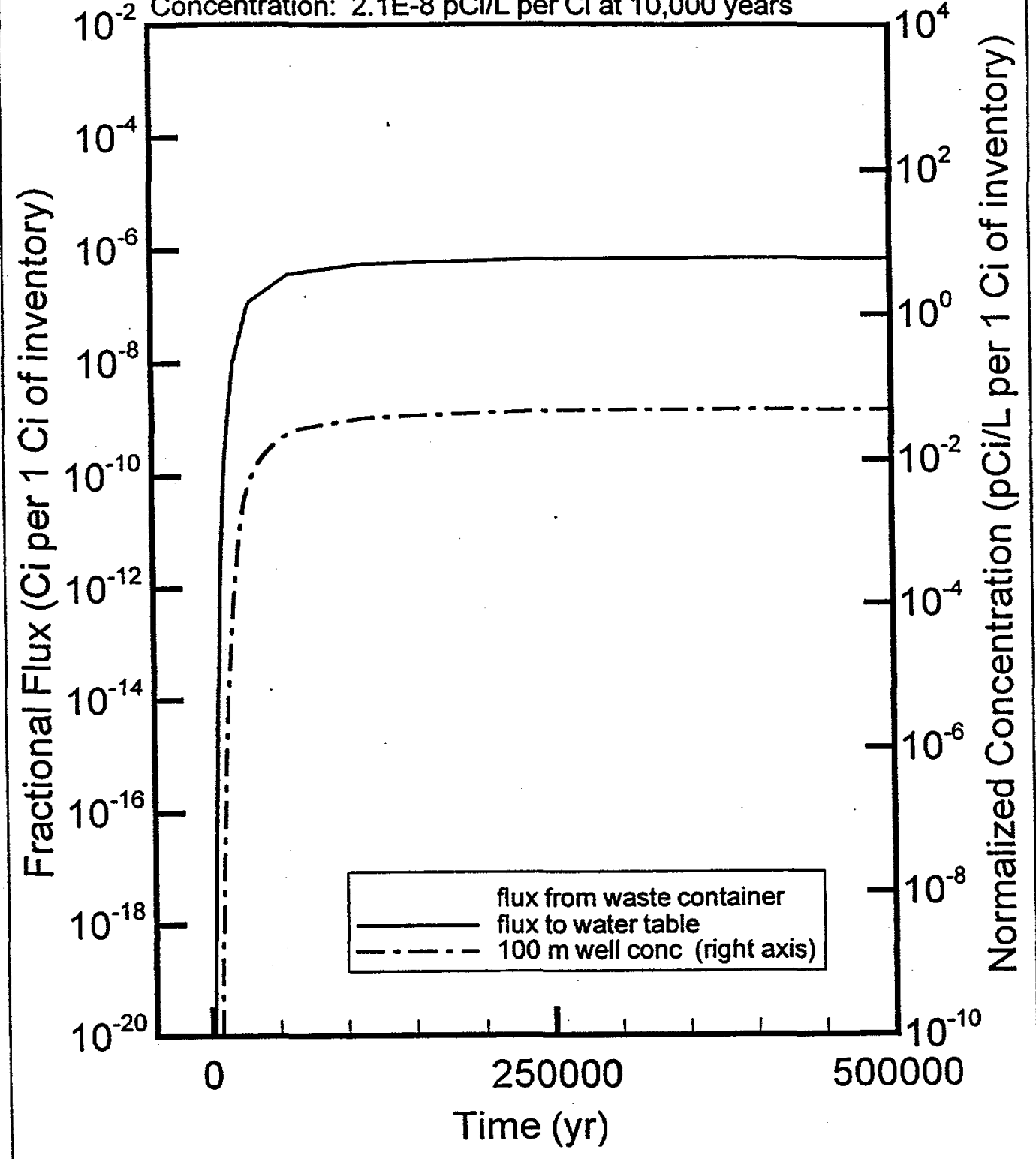

Figure 4.4.28. Flux and Concentration Results for Sm-146 


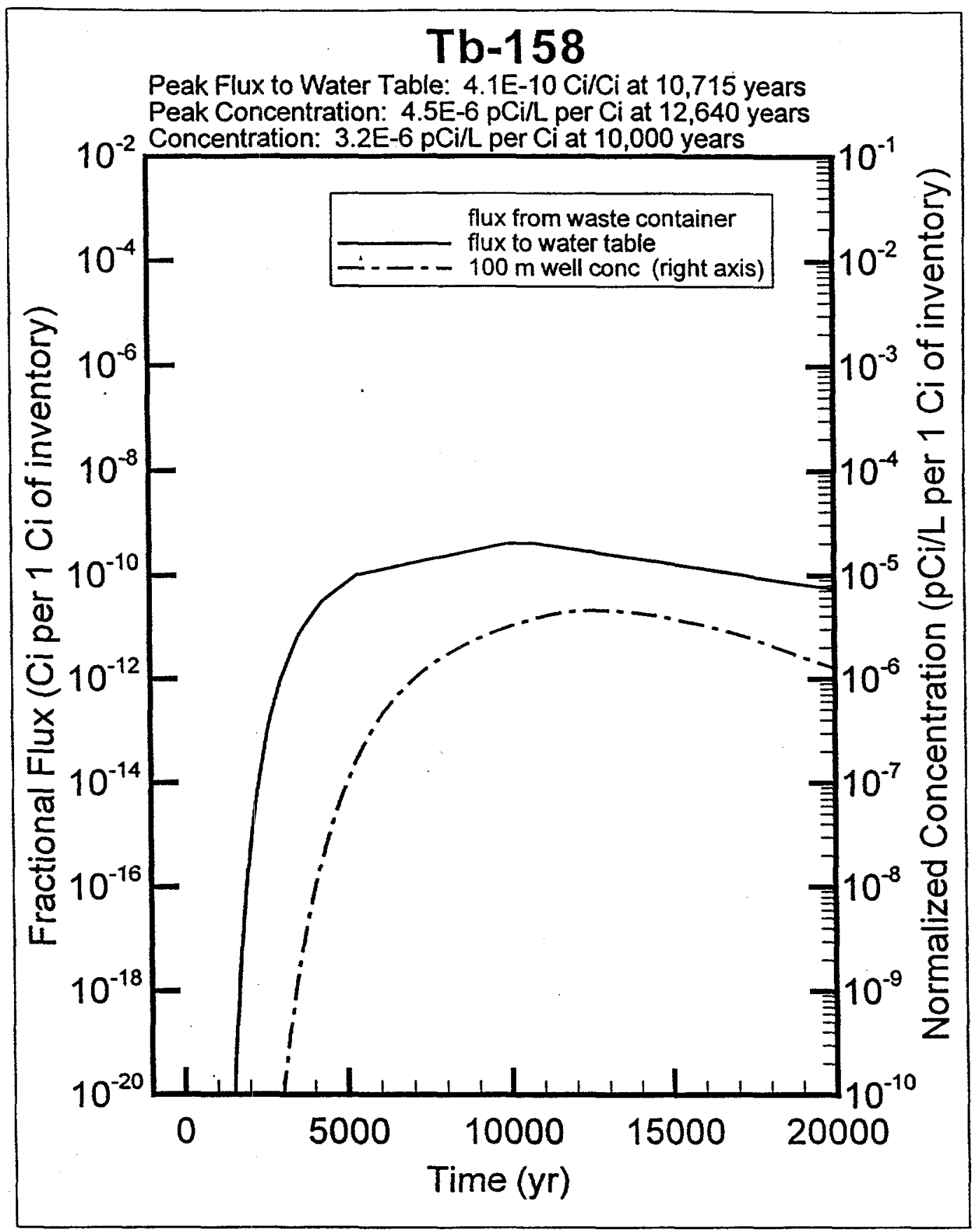

Figure 4.4.29. Flux and Concentration Results for Tb-158 


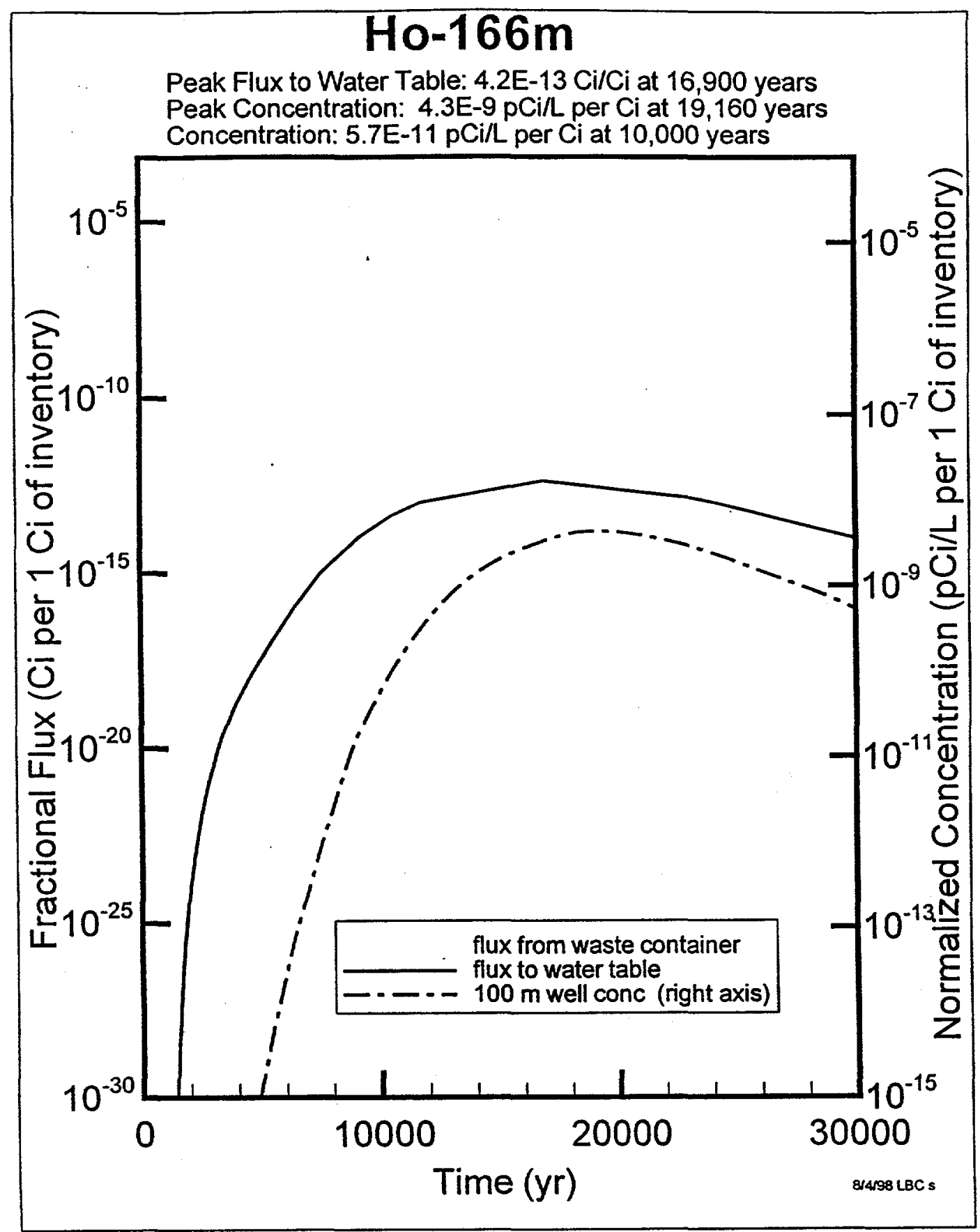

Figure 4.4.30. Flux and Concentration Results for Ho-166m 


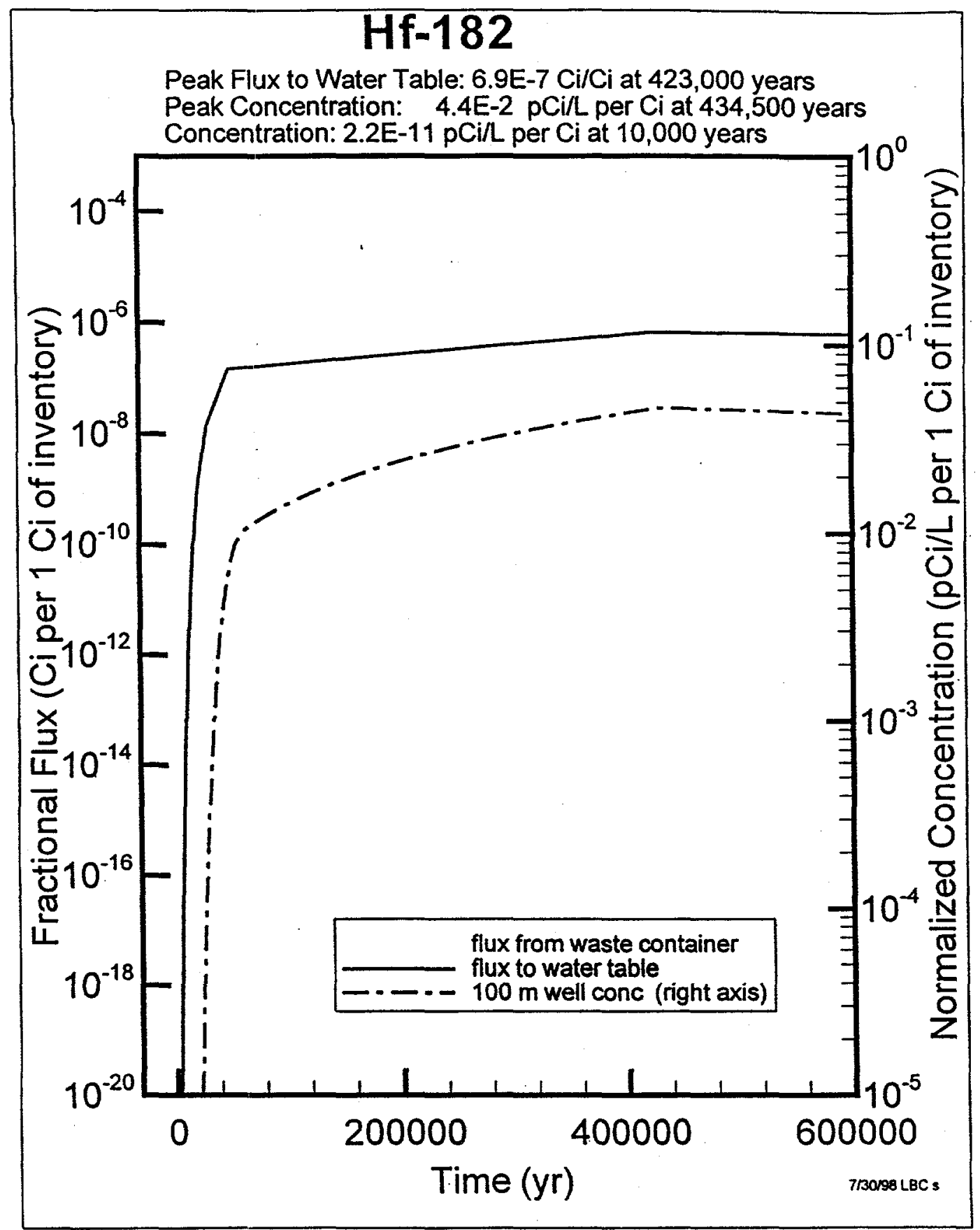

Figure 4.4.31. Flux and Concentration Results for Hf-182 


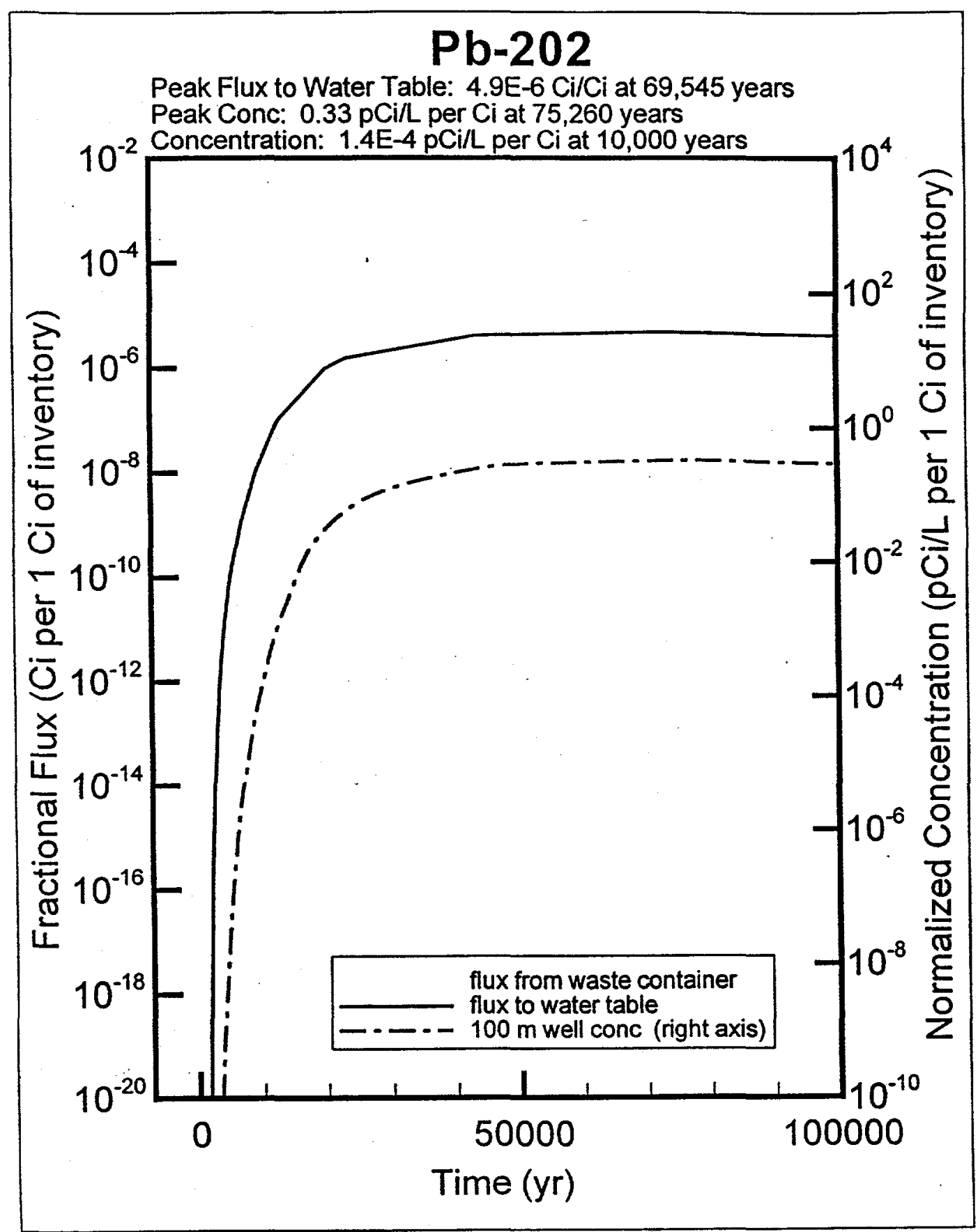

Figure 4.4.32. Flux and Concentration Results for $\mathbf{P b}-202$ 


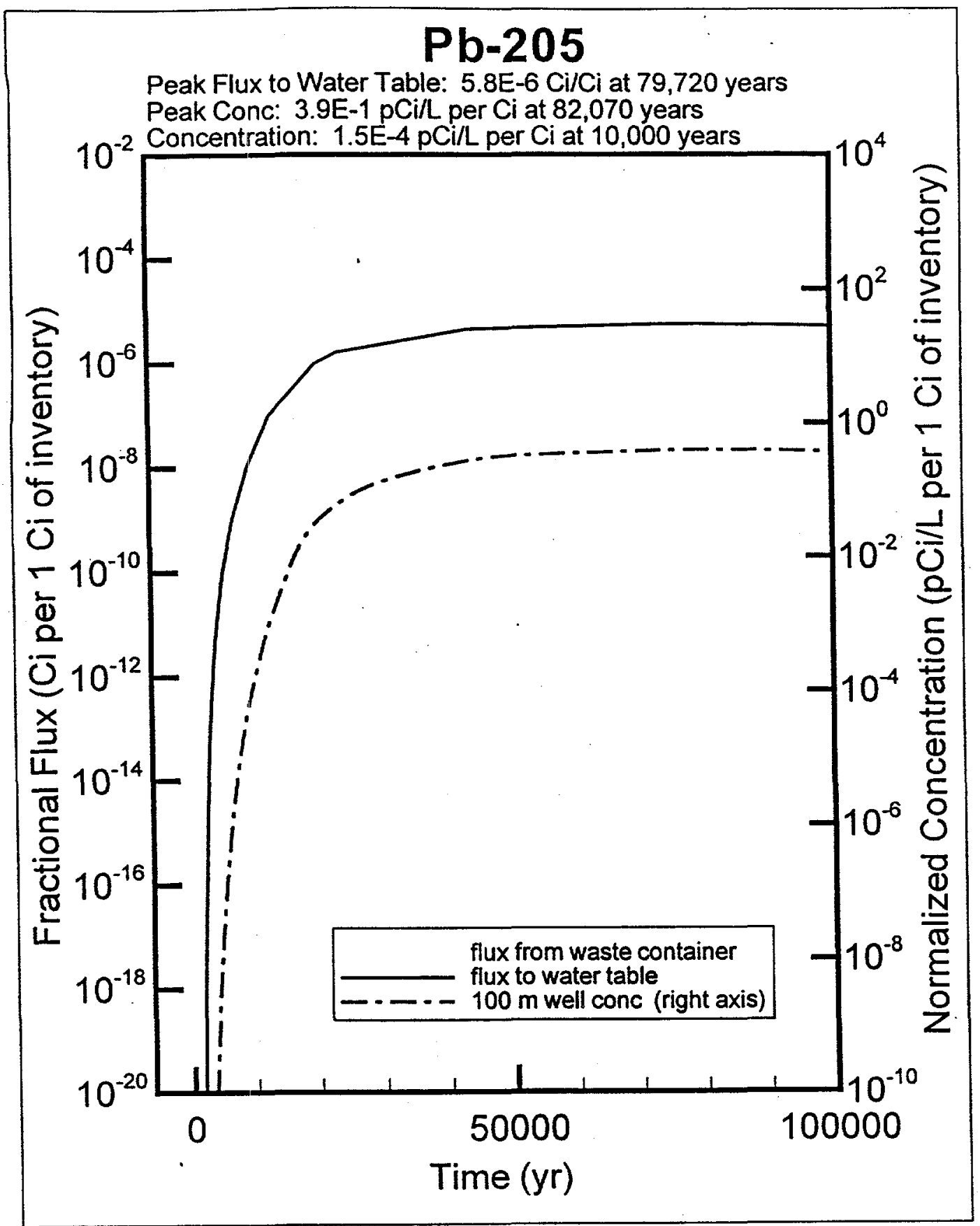

Figure 4.4.33. Flux and Concentration Results for $\mathbf{P b}-205$ 


\subsection{Air Pathway Analysis}

Screening analyses ${ }^{12}$ show that only volatile emissions, such as HTO (tritiated water vapor), HT (tritiated hydrogen), ${ }^{14} \mathrm{C}$ and ${ }^{36} \mathrm{Cl}$ and radioactive isotopes of the noble gasses, ${ }^{39} \mathrm{Ar},{ }^{42} \mathrm{Ar},{ }^{81} \mathrm{Kr},{ }^{85} \mathrm{Kr}$ and ${ }^{127} \mathrm{Xe}$ could produce doses of concern via the air pathway. In this section the release mechanisms used in the air pathway analysis are described.

\subsubsection{Tritium Wasteforms}

A study of tritium permeation from APT and TEF waste packages ${ }^{20}$ was conducted to help plan waste disposal operations for these proposed projects. The waste packages analyzed included the Aluminum, Window, Tungsten, Lead and Steel packages for the APT project and the overpack of extracted Tritium Producing Burnable Absorber Rods (TPBARs) of the TEF project. All of the tritium contained in the waste was assumed to be available as a gas in the free volume inside the waste container at the beginning of disposal, and then to permeate the stainless steel waste container. From estimates of the tritium content of each wasteform, the void or free volume of the package, disposal temperature and container geometry, the amount of tritium permeation was calculated. Two tritium permeation paths were considered separately; through the entire wall surface area and through the weld area only, the weld area having reduced thickness and significantly less surface area compared to the wall area. Permeation out of the five APT waste containers at $50^{\circ} \mathrm{C}$, the estimated disposal temperature, is mainly through the welds. Permeation from the TEF overpacks at the expected disposal temperature of $50^{\circ} \mathrm{C}$ is mainly through the entire wall surface area. Input parameters used in the study are given in Tables $4.5-1$ and $4.5-2$ for the APR and TEF containers, respectively. The results of the study are given in Table 4.5-3.

\begin{tabular}{|l|c|c|c|c|c|}
\hline $\begin{array}{l}\text { Table 4.5-1. Input Parameters Used for APT Waste Container Tritium Permeation } \\
\text { Calculation }{ }^{20}\end{array}$ & Aluminum & Window & Tungsten & Lead & Steel \\
\hline & 0.5 & 0.5 & 0.5 & 0.5 & 0.5 \\
\hline Wall Thickness (in) & 0.25 & 0.25 & 0.25 & 0.25 & 0.25 \\
\hline Weld Thickness (in) & 0.5 & 0.5 & 0.5 & 0.5 & 0.5 \\
\hline Weld Width (in) & 6 & 12 & 6 & 6 & 6 \\
\hline Container Length (ft) & 4 & 4 & 2 & 4 & 4 \\
\hline Container Width (ft) & 4 & 4 & 2 & 2 & 2 \\
\hline Container Height & 0.116 & 1.357 & 2.590 & 0.147 & 1.357 \\
\hline $\begin{array}{l}\text { Tritium Content of Waste after } \\
\text { Interim Storage Period (Ci/cc) }\end{array}$ & 2 & 5 & 5 & 2 & 5 \\
\hline Interim Storage Period (year) & 50,100 & 50,100 & 50,100 & 50,100 & 50,100 \\
\hline Temperature ( ${ }^{\circ}$ C) & & & & & \\
\hline
\end{tabular}




\begin{tabular}{|l|c|}
\hline $\begin{array}{c}\text { Table 4.5-2. Input Parameters Used for TEF } \\
\text { Container Tritium Permeation Calculation }\end{array}$ \\
\hline Wall Thickness (in) & 0.188 \\
\hline Weld Thickness (in) & 0.1225 \\
\hline Weld Width (in) & 0.25 \\
\hline Inside Diameter (ft) & 1.468 \\
\hline Length (ft) & 16 \\
\hline Void volume (cu. ft.) & 12.9 \\
\hline Tritium content per rod (Ci) & 133 \\
\hline Number of Rods per package & 300 \\
\hline Waste Storage Temperature $\left({ }^{\circ} \mathrm{C}\right)$ & 40 \\
\hline
\end{tabular}

\begin{tabular}{|c|c|c|c|c|c|c|c|c|}
\hline $\begin{array}{l}\text { Container \& } \\
\text { Path }\end{array}$ & \begin{tabular}{|c|} 
Tritium \\
Content \\
Of \\
Waste, $\mathrm{Ci}$ \\
\end{tabular} & $\begin{array}{c}\text { Thickness } \\
\text { (inch) }\end{array}$ & \begin{tabular}{|c|} 
Temperature \\
$\left({ }^{\circ} \mathrm{C}\right)$
\end{tabular} & $\begin{array}{c}\text { Surface } \\
\text { Area } \\
(\mathrm{cm} 2)\end{array}$ & $\begin{array}{c}\text { Maximum } \\
\text { Permeation Rate } \\
\left(\mathrm{cm}^{3} \mathrm{~T} / \mathrm{cm} 2 / \mathrm{s}\right)\end{array}$ & $\begin{array}{c}\text { Total } \\
\text { Tritium } \\
\text { Outgas } \\
\text { (Ci) } \\
\end{array}$ & \begin{tabular}{|c} 
Maximum \\
Annual Offgas \\
Rate \\
(Ci/year)
\end{tabular} & $\begin{array}{l}\text { Time to } \\
\text { Maximum } \\
\text { Offgas } \\
\text { Rate } \\
\text { (year) }\end{array}$ \\
\hline $\begin{array}{l}\text { TEF Overpack } \\
\text { Container }\end{array}$ & 39,900 & 0.188 & 40 & 70,016 & $2.3 \mathrm{E}-18$ & 1.3E-03 & $1.3 \mathrm{E}-05$ & 115 \\
\hline $\begin{array}{l}\text { TEF Overpack } \\
\text { Weld }\end{array}$ & & 0.125 & 40 & 91 & $1.8 \mathrm{E}-16$ & $1.1 \mathrm{E}-04$ & $1.3 \mathrm{E}-06$ & 80 \\
\hline $\begin{array}{l}\text { Aluminum } \\
\text { Container }\end{array}$ & $1.88 \mathrm{E}+05$ & 0.5 & 50 & 118,916 & $6.0 \mathrm{E}-23$ & $7.7 \mathrm{E}-08$ & $5.8 \mathrm{E}-10$ & 195 \\
\hline Aluminum Weld & & 0.25 & 50 & 774 & $6.4 \mathrm{E}-18$ & $4.0 \mathrm{E}-05$ & $4.1 \mathrm{E}-07$ & 113 \\
\hline Lead Container & $9.99 \mathrm{E}+04$ & 0.5 & 50 & 81,755 & $5.5 \mathrm{E}-23$ & $4.9 \mathrm{E}-08$ & $3.7 \mathrm{E}-10$ & 195 \\
\hline Lead Weld & & 0.25 & 50 & 774 & $5.9 \mathrm{E}-18$ & 3.7E-05 & $3.7 \mathrm{E}-07$ & 113 \\
\hline $\begin{array}{l}\text { Tungsten } \\
\text { Container }\end{array}$ & $5.28 E+05$ & 0.5 & 50 & 52,026 & $1.5 \mathrm{E}-22$ & 8.5E-08 & $6.4 \mathrm{E}-10$ & 195 \\
\hline Tungsten Weld & & 0.25 & 50 & 619 & $1.6 \mathrm{E}-17$ & $8.2 \mathrm{E}-05$ & $8.2 \mathrm{E}-07$ & 113 \\
\hline $\begin{array}{l}\text { Window } \\
\text { Container }\end{array}$ & $3.69 \mathrm{E}+06$ & 0.5 & 50 & 208,103 & $1.7 \mathrm{E}-22$ & $3.8 \mathrm{E}-07$ & $2.8 \mathrm{E}-09$ & 195 \\
\hline Window Weld & & 0.25 & 50 & 1,239 & $1.8 \mathrm{E}-17$ & $1.8 \mathrm{E}-04$ & $1.8 \mathrm{E}-06$ & 113 \\
\hline Steel Container & $9.22 E+05$ & 0.5 & 50 & 81,755 & $1.7 \mathrm{E}-22$ & $1.5 \mathrm{E}-07$ & $1.1 \mathrm{E}-09$ & 195 \\
\hline Steel Weld & & 0.25 & 50 & 774 & $1.8 \mathrm{E}-17$ & $1.1 \mathrm{E}-04$ & $1.1 \mathrm{E}-06$ & 113 \\
\hline
\end{tabular}

Note: Two container/paths labeled TEF refer to the Commercial Light Water Reactor - Tritium Extraction Facility project, all others are for the Accelerator Production of Tritium Project (APT). 


\subsubsection{Carbon- $14,{ }^{36} \mathrm{Cl}$ and the Noble Gasses}

$\mathrm{C}-14, \mathrm{Cl}-36$ and radioisotopes of the noble gasses will be formed within the metal matrix of the wasteforms. Therefore, it is assumed that they will be released at the same rate as the wasteforms corrode. Corrosion of the APT and TEF wasteforms has been studied ${ }^{14}$. The results for each of the wasteform and container materials are presented in Table 4.5-4.

\section{Table 4.5-4. Corrosion rates for APT and TEF Materials}

\begin{tabular}{|c|c|}
\hline Wasteform or Material & Corrosion Rate $(\mu \mathrm{m} / \mathrm{yr})$ \\
\hline Aluminum & 25.4 \\
\hline Lead & 7 \\
\hline Tungsten & 13 \\
\hline Inconel & $2.5 \mathrm{E}-03$ \\
\hline Stainless Steel & $2.5 \mathrm{E}-03$ \\
\hline TEF (TPBARs and Baseplates) & $2.5 \mathrm{E}-03$ \\
\hline
\end{tabular}

The wasteforms were assumed to be $1.27 \mathrm{~cm}(0.5$ in) thick. Assuming that the wasteform corrodes from both sides, the time for the wasteform to completely corrode through its entire thickness is:

$$
\text { Time }(\mathrm{yr})=1.27 \mathrm{~cm} /[2 * \text { corrosion rate }(\mathrm{cm} / \mathrm{yr})]
$$

Assuming that ${ }^{14} \mathrm{C},{ }^{36} \mathrm{Cl}$, and the radioactive noble gasses are uniformly distributed throughout the wasteforms, they will be uniformly released over the period of time calculated above. The annual release rate is therefore the inverse of the corrosion time. These results are given in Table 4.5-5

\section{Table 4.5.5. Release fractions for C-14, Cl-36, and noble gasses from APT and TEF wasteforms}

\begin{tabular}{|c|c|c|}
\hline Wasteform or Material & Corrosion Time $(\mathrm{yr})$ & Annual Release Rate $\left(\mathrm{yr}^{-1}\right)$ \\
\hline Aluminum & 250 & $4.0 \mathrm{E}-03$ \\
\hline Lead & 910 & $1.1 \mathrm{E}-03$ \\
\hline Tungsten & 490 & $2.0 \mathrm{E}-03$ \\
\hline Inconel & $2.5 \mathrm{E} 6$ & $3.9 \mathrm{E}-7$ \\
\hline Stainless & $2.5 \mathrm{E} 6$ & $3.9 \mathrm{E}-7$ \\
\hline TEF (TPBARs and Baseplates) & $2.5 \mathrm{E} 6$ & $3.9 \mathrm{E}-7$ \\
\hline
\end{tabular}

\subsubsection{Air Pathways Exposure Analysis}

Human exposure calculations related to the air pathway include six pathways; plume shine, ground deposition, inhalation, vegetation consumption, milk consumption and meat consumption. Parameter selection was made to maximize the calculated dose. The parameters are given in Table 4.5-6.

Two points and times of exposure were used in the analysis. For the first 100 years, the minimum time for which institutional control will be maintained, the point of maximum exposure will be at the SRS boundary, about $11 \mathrm{~km}$ north of E-Area. Doses were also calculated at a point $100-\mathrm{m}$ from the E-Area Disposal Facility at 100 years after closure. The dose limit used in the air pathway analysis is $10 \mathrm{mrem} / \mathrm{yr}$, effective dose equivalent, as required by 40 CFR 61. This dose limit was applied at both points of exposure, $100-\mathrm{m}$ from the disposal facility and at the SRS boundary. 


\section{Table 4.5-6. Parameters used in air dose calculations}

\begin{tabular}{|l|l|}
\hline Relative Concentration (X/Q): & $1.70 \mathrm{E}-04(\mathrm{sec} / \mathrm{m} 3)$ \\
\hline Decayed X/Q: & $1.70 \mathrm{E}-04(\mathrm{sec} / \mathrm{m} 3)$ \\
\hline Depleted X/Q: & $1.70 \mathrm{E}-04(\mathrm{sec} / \mathrm{m} 3)$ \\
\hline Relative Deposition (D/Q): & $5.20 \mathrm{E}-07(1 / \mathrm{m} 2)$ \\
\hline Distance to Receptor: & $100(\mathrm{~m})$ \\
\hline Vegetable Consumption: & $276(\mathrm{~kg} / \mathrm{yr})$ \\
\hline Leafy Vegetable Consumption: & $43(\mathrm{~kg} / \mathrm{yr})$ \\
\hline Milk Consumption: & $230(\mathrm{~L} / \mathrm{yr})$ \\
\hline Meat Consumption: & $81(\mathrm{~kg} / \mathrm{yr})$ \\
\hline Origin of Milk: & cow \\
\hline Deposition Buildup Time: & $25(\mathrm{yr})$ \\
\hline Breathing Rate: & $8,000(\mathrm{~m} 3 / \mathrm{yr})$ \\
\hline Elemental Iodine Fraction: & 1 \\
\hline Absolute Humidity: & $0.0114(\mathrm{~kg} / \mathrm{m} 3)$ \\
\hline Tritium Plant-to-Air Ratio: & 0.5 \\
\hline Shielding Factor: & 0.23 \\
\hline Fraction of Year C-14 Released: & 1 \\
\hline Retained Fraction (iodine): & 1 \\
\hline Retained Fraction (particulates): & 0.2 \\
\hline Weathering Rate Constant: & $18.1(1 / \mathrm{yr})$ \\
\hline Crop Exposure Time: & $0.164(\mathrm{yr})$ \\
\hline Pasture Grass Exposure Time: & $0.0822(\mathrm{yr})$ \\
\hline Pasture Grass Productivity: & $1.8(\mathrm{~kg} / \mathrm{m} 2)$ \\
\hline Produce Productivity: & $0.7(\mathrm{~kg} / \mathrm{m} 2)$ \\
\hline Surface Soil Density (15 cm): & $240(\mathrm{~kg} / \mathrm{m} 2)$ \\
\hline Pasture Grass Holdup Time: & $0(\mathrm{yrs})$ \\
\hline Stored Feed Holdup Time: & $0.247(\mathrm{yrs)}$ \\
\hline Leafy Vegetable Holdup Time: & $0.00274(\mathrm{yrs})$ \\
\hline Produce Holdup Time: & $0.164(\mathrm{yrs})$ \\
\hline Milk Cattle Feed Consumption: & $44(\mathrm{~kg} / \mathrm{day})$ \\
\hline Beef Cattle Feed Consumption: & $44(\mathrm{~kg} / \mathrm{day})$ \\
\hline Feed-Milk-Man Transport Time: & $0.00548(\mathrm{yr})$ \\
\hline Fraction of Year on Pasture (beef): & 1 \\
\hline Fraction of Year on Pasture (milk): & 1 \\
\hline Fraction Intake from Pasture (beef): & 0.75 \\
\hline Fraction Intake from Pasture (milk): & 0.56 \\
\hline Slaughter to Consumption Time: & $0.0164(\mathrm{yr})$ \\
\hline Fraction of Produce from Garden: & 0.76 \\
\hline Fraction of Leafy Vegetables from Garden: & 1 \\
\hline & \\
\hline
\end{tabular}

Doses for unit releases of ${ }^{3} \mathrm{H},{ }^{14} \mathrm{C}$ and the radioactive noble gasses were calculated at the site boundary ${ }^{21,22}$ using the MAXIGASP computer program ${ }^{23}$. Doses for unit releases at the E-Area boundary were calculated ${ }^{24}$ using the MAXINE spreadsheet ${ }^{25}$ that implements the MAXIGASP methodology. The results are shown in Table 4.5-7. 


\section{Table 4,5-7. Dose factors for the air pathway}

\begin{tabular}{|l|c|c|}
\hline Radionuclide & $\begin{array}{c}100-\mathrm{m} \text { location } \\
\text { (mrem/yr-Ci Released) }\end{array}$ & $\begin{array}{c}\text { Site Boundary Location } \\
\text { (mrem/yr-Ci Released) }\end{array}$ \\
\hline $\mathrm{H}-3$ & $8.5 \mathrm{E}-03$ & $2.4 \mathrm{E}-06$ \\
\hline $\mathrm{C}-14$ & $3.8 \mathrm{E}+00$ & $1.0 \mathrm{E}-03$ \\
\hline $\mathrm{Cl}-36$ & $8.7 \mathrm{E}+02$ & $2.5 \mathrm{E}-01$ \\
\hline $\mathrm{Ar}-39$ & $1.3 \mathrm{E}-06$ & $1.1 \mathrm{E}-09$ \\
\hline $\mathrm{Ar}-42$ & $1.6 \mathrm{E}-03$ & $1.4 \mathrm{E}-06$ \\
\hline $\mathrm{Kr}-81$ & $6.3 \mathrm{E}-05$ & $5.3 \mathrm{E}-08$ \\
\hline $\mathrm{Kr}-85$ & $1.4 \mathrm{E}-05$ & $1.2 \mathrm{E}-08$ \\
\hline $\mathrm{Xe}-127$ & $1.6 \mathrm{E}-03$ & $1.4 \mathrm{E}-06$ \\
\hline
\end{tabular}

Potential doses via the air pathway were estimated using the following equation:

Dose $=$ Projected Inventory (Table 4.3-2) $\times$ Release Rate $\times$ Dose factor $\times \mathrm{e}^{-\lambda \mathrm{e}}$, where $t=100$ years for the $100-m$ location and 0 for the SRS boundary.

The maximum annual release fraction for tritium from the various wasteforms was calculated from the data in Table 4.5-3 by dividing the maximum annual offgas rate ( $\mathrm{Ci} /$ year) by the tritium content of the waste ( $\mathrm{Ci}$ ).

The results for the case at the E-Area boundary after 100 years of institutional control, and the SRS boundary immediately after closure are given in Tables 4.5-8 and 4.5-9, respectively. The greater of the two doses for each wasteform is given in Table 4.5-10, and the total dose for APT low-level wasteforms, the lead wasteform and TEF wasteforms is given in table 4.5-11. The doses for the APT and TEF wasteforms in Tables 4.5-8 through 4.5-11 were conservatively calculated based on the maximum offgas rate during a single year from all of the waste containers expected to be produced over 40 years of operation.

Table 4.5-8. Potential doses via the air pathway at the E-Area boundary after 100 years of
institutional control
\begin{tabular}{|l|c|c|c|c|c|c|}
\hline & \multicolumn{7}{|c|}{ Doses (mrem/year) } \\
\hline Radionuclide & Tungsten & Window & Steel & Aluminum & Lead & TEF \\
\hline $\mathrm{H}-3$ & $9.8 \mathrm{E}-10$ & $1.0 \mathrm{E}-12$ & $2.5 \mathrm{E}-12$ & $1.4 \mathrm{E}-10$ & $2.6 \mathrm{E}-09$ & $1.6 \mathrm{E}-05$ \\
\hline $\mathrm{C}-14$ & $2.1 \mathrm{E}-02$ & $1.2 \mathrm{E}-06$ & $1.2 \mathrm{E}-06$ & $2.5 \mathrm{E}+00$ & $1.7 \mathrm{E}+01$ & $2.5 \mathrm{E}-03$ \\
\hline $\mathrm{Cl}-36$ & $5.2 \mathrm{E}+00$ & $1.1 \mathrm{E}-04$ & $1.1 \mathrm{E}-04$ & $1.1 \mathrm{E}-09$ & $5.3 \mathrm{E}+00$ & $0.0 \mathrm{E}+00$ \\
\hline $\mathrm{Ar}-39$ & $2.4 \mathrm{E}-06$ & $4.7 \mathrm{E}-11$ & $4.7 \mathrm{E}-11$ & $3.3 \mathrm{E}-13$ & $6.7 \mathrm{E}-07$ & $4.6 \mathrm{E}-10$ \\
\hline $\mathrm{Ar}-42$ & $6.3 \mathrm{E}-05$ & $9.2 \mathrm{E}-15$ & $9.2 \mathrm{E}-15$ & $1.9 \mathrm{E}-13$ & $1.4 \mathrm{E}-03$ & $0.0 \mathrm{E}+00$ \\
\hline $\mathrm{Kr}-81$ & $2.0 \mathrm{E}-07$ & $8.8 \mathrm{E}-13$ & $8.8 \mathrm{E}-13$ & $0.0 \mathrm{E}+00$ & $4.3 \mathrm{E}-07$ & $0.0 \mathrm{E}+00$ \\
\hline $\mathrm{Kr}-85$ & $1.8 \mathrm{E}-08$ & $1.2 \mathrm{E}-17$ & $1.2 \mathrm{E}-17$ & $0.0 \mathrm{E}+00$ & $8.9 \mathrm{E}-07$ & $0.0 \mathrm{E}+00$ \\
\hline $\mathrm{Xe}-127$ & $0.0 \mathrm{E}+00$ & $0.0 \mathrm{E}+00$ & $0.0 \mathrm{E}+00$ & $0.0 \mathrm{E}+00$ & $0.0 \mathrm{E}+00$ & $0.0 \mathrm{E}+00$ \\
\hline
\end{tabular}




\begin{tabular}{|l|c|c|c|c|c|c|}
\hline \multicolumn{7}{|c|}{ Table 4.5-9. Potential doses via the air pathway at the SRS boundary } \\
\hline & \multicolumn{7}{|c|}{ Doses (mrem/year) } \\
\hline & Tungsten & Window & Steel & Aluminum & Lead & TEF \\
\hline $\mathrm{H}-3$ & $9.0 \mathrm{E}-11$ & $9.4 \mathrm{E}-14$ & $2.3 \mathrm{E}-13$ & $1.2 \mathrm{E}-11$ & $2.4 \mathrm{E}-10$ & $1.5 \mathrm{E}-06$ \\
\hline $\mathrm{C}-14$ & $5.6 \mathrm{E}-06$ & $3.1 \mathrm{E}-10$ & $3.1 \mathrm{E}-10$ & $6.6 \mathrm{E}-04$ & $4.5 \mathrm{E}-03$ & $6.6 \mathrm{E}-07$ \\
\hline $\mathrm{Cl}-36$ & $1.5 \mathrm{E}-03$ & $3.1 \mathrm{E}-08$ & $3.1 \mathrm{E}-08$ & $3.2 \mathrm{E}-13$ & $1.5 \mathrm{E}-03$ & $0.0 \mathrm{E}+00$ \\
\hline $\mathrm{Ar}-39$ & $2.6 \mathrm{E}-09$ & $5.1 \mathrm{E}-14$ & $5.1 \mathrm{E}-14$ & $3.6 \mathrm{E}-16$ & $7.3 \mathrm{E}-10$ & $5.0 \mathrm{E}-13$ \\
\hline $\mathrm{Ar}-42$ & $4.5 \mathrm{E}-07$ & $6.6 \mathrm{E}-17$ & $6.6 \mathrm{E}-17$ & $1.4 \mathrm{E}-15$ & $9.6 \mathrm{E}-06$ & $0.0 \mathrm{E}+00$ \\
\hline $\mathrm{Kr}-81$ & $1.7 \mathrm{E}-10$ & $7.4 \mathrm{E}-16$ & $7.4 \mathrm{E}-16$ & $0.0 \mathrm{E}+00$ & $3.6 \mathrm{E}-10$ & $0.0 \mathrm{E}+00$ \\
\hline $\mathrm{Kr}-85$ & $8.6 \mathrm{E}-19$ & $5.6 \mathrm{E}-28$ & $5.6 \mathrm{E}-18$ & $0.0 \mathrm{E}+00$ & $4.1 \mathrm{E}-17$ & $0.0 \mathrm{E}+00$ \\
\hline $\mathrm{Xe}-127$ & $0.0 \mathrm{E}+00$ & $0.0 \mathrm{E}+00$ & $0.0 \mathrm{E}+00$ & $0.0 \mathrm{E}+00$ & $4.5 \mathrm{E}-34$ & $0.0 \mathrm{E}+00$ \\
\hline
\end{tabular}

\begin{tabular}{|l|c|c|c|c|c|c|}
\hline Table 4.5-10. & Maximum dose via the air pathway \\
\hline & \multicolumn{7}{|c|}{ Doses (mrem/year) } \\
\hline Radionuclide & Tungsten & Window & Steel & Aluminum & Lead & TEF \\
\hline $\mathrm{H}-3$ & $9.8 \mathrm{E}-10$ & $1.0 \mathrm{E}-12$ & $2.5 \mathrm{E}-12$ & $1.4 \mathrm{E}-10$ & $2.6 \mathrm{E}-09$ & $1.6 \mathrm{E}-05$ \\
\hline $\mathrm{C}-14$ & $2.1 \mathrm{E}-02$ & $1.2 \mathrm{E}-06$ & $1.2 \mathrm{E}-06$ & $2.5 \mathrm{E}+00$ & $1.7 \mathrm{E}+01$ & $2.5 \mathrm{E}-03$ \\
\hline $\mathrm{Cl}-36$ & $5.2 \mathrm{E}+00$ & $1.1 \mathrm{E}-04$ & $1.1 \mathrm{E}-04$ & $1.1 \mathrm{E}-09$ & $5.3 \mathrm{E}+00$ & $0.0 \mathrm{E}+00$ \\
\hline Ar-39 & $2.4 \mathrm{E}-06$ & $4.7 \mathrm{E}-11$ & $4.7 \mathrm{E}-11$ & $3.3 \mathrm{E}-13$ & $6.7 \mathrm{E}-07$ & $4.6 \mathrm{E}-10$ \\
\hline Ar-42 & $6.3 \mathrm{E}-05$ & $9.2 \mathrm{E}-15$ & $9.2 \mathrm{E}-15$ & $1.9 \mathrm{E}-13$ & $1.4 \mathrm{E}-03$ & $0.0 \mathrm{E}+00$ \\
\hline $\mathrm{Kr}-81$ & $2.0 \mathrm{E}-07$ & $8.8 \mathrm{E}-13$ & $8.8 \mathrm{E}-13$ & $0.0 \mathrm{E}+00$ & $4.3 \mathrm{E}-07$ & $0.0 \mathrm{E}+00$ \\
\hline $\mathrm{Kr}-85$ & $1.8 \mathrm{E}-08$ & $1.2 \mathrm{E}-17$ & $1.2 \mathrm{E}-17$ & $0.0 \mathrm{E}+00$ & $8.9 \mathrm{E}-07$ & $0.0 \mathrm{E}+00$ \\
\hline Xe-127 & $0.0 \mathrm{E}+00$ & $0.0 \mathrm{E}+00$ & $0.0 \mathrm{E}+00$ & $0.0 \mathrm{E}+00$ & $0.0 \mathrm{E}+00$ & $0.0 \mathrm{E}+00$ \\
\hline Total & $5.2 \mathrm{E}+00$ & $1.1 \mathrm{E}-04$ & $1.1 \mathrm{E}-04$ & $2.5 \mathrm{E}+00$ & $2.2 \mathrm{E}+01$ & $2.5 \mathrm{E}-03$ \\
\hline
\end{tabular}

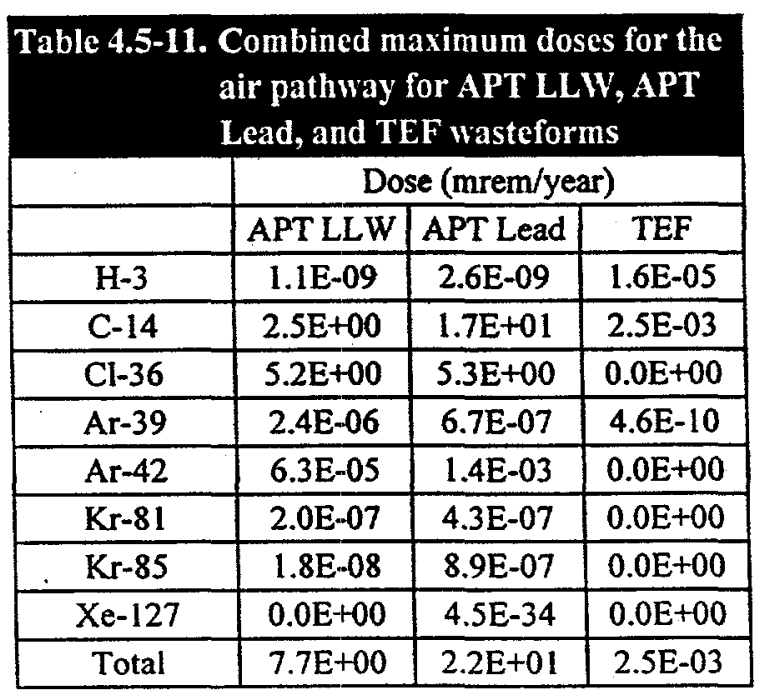




\section{6}

Inadvertent Intruder Analysis

As described in Sect. 2.3.3, disposal of low-level radioactive waste in the E-Area Low Level Waste Facility (LLWF) must meet a performance objective for protection of inadvertent intruders onto the disposal site. In particular, after a potential lapse of active institutional control at 100 years after facility closure, the effective dose equivalent (EDE) to an intruder should not exceed 100 mrem per year for scenarios involving continuous exposure or $500 \mathrm{mrem}$ for scenarios involving a single acute exposure. These dose limits apply to the sum of dose equivalents from all exposure pathways that are assumed to occur in a given exposure scenario for an inadvertent intruder.

In this section, exposure scenarios for an inadvertent intruder are described. These scenarios are then compared to identify the dominant scenarios in terms of total exposure to radionuclides present in a disposal unit (Sect. 4.6.1). Section 4.6.2 summarizes a screening analysis by which radionuclides of potential significance to estimated doses are identified. Analysis of dose to inadvertent intruders for the potentially significant scenarios and radionuclides is also described, and results of the dose calculations are presented (Sect. 4.6.3).

The focus in developing exposure scenarios for inadvertent intruders was on selecting reasonable events that may occur, giving consideration to regional customs and construction practices. An important assumption in all scenarios is that an intruder has no prior knowledge of the existence of a waste disposal facility at the site. Therefore, certain exposure scenarios are assumed to be precluded only by the physical state of the disposal facility, i.e., the integrity of the engineered barriers used in facility construction.

\subsubsection{Exposure Scenarios for Inadvertent Intruders}

\subsubsection{Chronic Exposure Scenarios for Inadvertent Intruders}

We considered three distinct scenarios resulting in chronic exposure of inadvertent intruders. Two of these scenarios, which usually are referred to as the agriculture (or homesteader) and post-drilling scenarios, are commonly used in performance assessments. The third scenario considered in this analysis is specific to the SRS LLWF. This scenario is referred to as the resident scenario. Assumptions made in defining the agriculture, resident, and post-drilling scenarios are discussed below.

\subsection{Agriculture Scenario}

The agriculture scenario assumes that an intruder comes onto the site and establishes a permanent homestead, including on-site sources of water and foodstuffs. Waste in disposal units is assumed to be accessed when an intruder constructs a home directly on top of a disposal facility and the foundation of the home extends into the facility itself. All waste in the disposal facility at the time the foundation is dug is assumed to be physically indistinguishable from native soil.

In the agriculture scenario, some of the waste exhumed from the disposal facility is assumed to be mixed with native soil in the intruder's vegetable garden. The following exposure pathways involving exhumed waste or waste remaining in the exposed disposal facility on which the intruder's home is located then are assumed to occur:

- ingestion of vegetables grown in contaminated garden soil;

- direct ingestion of contaminated soil, primarily in conjunction with intakes of garden vegetables ;

- external exposure to contaminated soil while working in the garden or residing in the home on top of the disposal facility; and

- inhalation of radionuclides attached to soil particles that are suspended into air from contaminated soil while working in the garden or residing in the home

\subsection{Resident Scenario}

As in the agriculture scenario described above, the resident scenario assumes that an intruder excavates a foundation for a home on top of a disposal facility. During excavation, however, the intruder may encounter an engineered barrier, such as the roof of a concrete vault, that cannot easily be penetrated by the types of excavation equipment normally used at the SRS. In these cases, the presence of intact engineered barriers or wasteforms is assumed to preclude direct intrusion into the waste during excavation. Instead of abandoning the site, the intruder constructs a home directly on top of the intact barrier or wasteform and, thus, establishes a residence at that location.

From the definition of the resident scenario, the primary exposure pathway of concern is external exposure to photon-emitting radionuclides during the time the intruder resides in the home on the disposal site. The presence of intact barriers and/or wasteforms would preclude any ingestion exposures and most inhalation exposures.

The resident scenario is assumed to occur at any time after closure of the disposal facility. However, even though the concentrations of most radionuclides in the disposal facility will decrease monotonically with time, due to radioactive decay and migration from the disposal facility, the dose in the resident scenario is not necessarily the 
highest at 100 years after facility closure. At 100 years after closure, the concrete roof on top of the intermediate level tritium vauits (ILTV) is assumed to be intact, thereby providing a substantial amount of shielding that greatly reduces the external dose from the waste. Also, the layer of uncontaminated grout on top of the waste provides a considerable amount of additional shielding. At some later time, however, the concrete roof is assumed to have lost its integrity and most of the layer of uncontaminated grout is assumed to have weathered to soil-equivalent material. These processes take hundreds to thousands of years or more. Therefore, for long-lived radionuclides that are retained in the waste for long periods of time, the external dose in the resident scenario would be considerably higher long after active institutional control ceases, when excavation essentially to the depth of the waste could occur.

Thus, for the resident scenario, the maximum dose to an inadvertent intruder and the time at which the maximum dose occurs depend on 1) the half-lives and concentrations of the important photon-emitting radionuclides in the waste, 2) the time period over which the engineered barriers above the waste lose their integrity and can easily be excavated, and 3) the rate at which the important radionuclides migrate from the disposal facility. The maximum dose for this scenario can be estimated by considering two bounding cases: 1) intrusion at 100 years after disposal; and 2) intrusion at a much later time. The first bounding case takes into account radionuclides of both shorter and longer half-lives and any shielding provided by concrete roofs or other barriers between the waste and the roof, whereas the second bounding case applies to time periods when only long-lived radionuclides are present, but the waste is assumed to be unshielded. In both cases, self-shielding provided by the waste and any encapsulating materials is taken into account in estimating external dose.

\subsection{Comparison of Agriculture and Resident Scenarios}

From the definition of the resident scenario, this scenario can be regarded as a variation of the agriculture scenario in which only one of the exposure pathways is potentially important; namely, external exposure while residing in the home located on top of the disposal facility. Therefore, since this exposure pathway is essentially the same in the two scenarios and the agriculture scenario includes other exposure pathways that are not relevant for the resident scenario, the agriculture scenario probably will be more important than the resident scenario. That is, the dose per unit concentration of radionuclides in disposed waste probably will be higher in the agriculture scenario than in the resident scenario. Thus, the agriculture scenario is expected to be more restrictive in regard to determining acceptable disposals.

However, a possibility exists that the resident scenario may result in higher doses than derived from the agriculture scenario if radionuclides are leached to a significant extent from the waste between the time the resident scenario occurs and the time the agriculture scenario can first occur. An example of this might be the case where the engineered barriers have degraded to soil-equivalent material, and can be excavated, but the wasteform itself cannot yet be excavated. In this case, the external dose from unshielded waste could be greater than the total dose from all exposure pathways that would result at a later time when excavation into the waste is possible. This could particularly be the case for the ILTV in which the waste is grouted, and thus may maintain its physical integrity past the time the overlying vault roof fails. Another possibility exists in which the doses from the resident scenario may exceed those from the agriculture scenario if shorter-lived radionuclides are important in the resident scenario at 100 years after disposal, when all engineered barriers are presumed to be intact, but have decayed significantly by the time the agricultural scenario may occur. Therefore, the resident scenario is considered in the intruder dose analysis for disposal units with engineered barriers (i.e., ILTV) that prevent excavation into the wasteform (i.e., as required for the agriculture scenario) at the time the resident scenario may occur (100 years post-closure and beyond).

\subsection{Post-Drilling Scenario}

The post-drilling scenario assumes that an intruder who resides permanently on the disposal site drills through a disposal unit in constructing a well for a domestic water supply. Following construction of the well, the contaminated material brought to the surface during drilling operations, which is assumed to be indistinguishable from native soil, is assumed to be mixed with native soil in the intruder's vegetable garden. The exposure pathways involving ingestion of contaminated vegetables, ingestion of contaminated soil, and external and inhalation exposures while working in the garden then are the same as the pathways described previously for the agriculture scenario. In the post-drilling scenario, however, external and inhalation exposures while residing in the home on the disposal site, which are important in the agriculture scenario, are not relevant, because all drilling waste is assumed to be mixed with native soil in the garden and the intruder's home is assumed not to be located directly on top of exposed waste.

In this analysis, as in the agriculture scenario, drilling through a disposal unit is assumed to be precluded during the time when the concrete vaults and steel containers maintain their integrity. For the ILTV, the post-drilling scenario involving drilling through a disposal facility is assumed not to be credible until the same time as the agriculture scenario involving direct excavation into the disposal facility. The basis for this assumption is that the types of drill bits normally used in constructing wells in the soft sand and clay soils at the SRS could not easily penetrate an intact concrete vault or other grouted wasteform or non-degraded steel container. Therefore, in attempting to drill directly through a disposal facility, it seems reasonable to assume that an intruder would encounter considerable resistance 
and, instead of taking extraordinary measures to obtain a drill bit designed to penetrate through hard rock or steel, would move the drilling operation to a different location away from the disposal facility.

\subsection{Comparison of Agriculture and Post-Drilling Scenarios}

Previous analyses of the agriculture and post-drilling scenarios have shown that the dose to an intruder per unit concentration of radionuclides in excavated material should be considerably greater for the agriculture scenario than for the post-drilling scenario, provided the assumptions for the exposure pathways in the two scenarios are reasonably consistent. The principal reasons for the greater doses in the agriculture scenario are 1) the greater volume of waste exhumed during construction of a foundation for a home compared with the volume of waste exhumed during drilling of a well, which results in greater concentrations of radionuclides in contaminated soil in the intruder's vegetable garden, and 2) the doses from external and inhalation exposure while residing in a home on the disposal site, which contribute to the dose for the agriculture scenario but are not relevant for the post-drilling scenario.

\subsubsection{Acute Exposure Scenarios for Intruders}

Three distinct scenarios resulting in acute exposure of inadvertent intruders have commonly been applied to LLW disposal facilities. These scenarios usually are referred to as the construction, discovery, and drilling scenarios. As noted previously, all acute exposure scenarios for inadvertent intruders are subject to a limit on EDE of $500 \mathrm{mrem}$. The following sections describe the three acute exposure scenarios and their potential importance in the intruder dose analysis.

\subsection{Construction Scenario}

The chronic agriculture scenario described in Sect. 6.1.1 is based on the assumption that an intruder builds a home on the disposal site, with the foundation extending into a disposal unit. The construction scenario considers exposures during the short period of time for digging a foundation and building a home.

During construction, the relevant exposure pathways are assumed to be inhalation of radionuclides suspended into air from an uncovered disposal unit and external exposure to photon-emitting radionuclides in the disposal unit. Ingestion exposure is assumed to be unimportant during normal work activities. The potential importance of the construction scenario arises primarily from the assumption that construction activities result in airborne concentrations of radionuclides that are substantially higher than those during normal activities while inhabiting the site, as in the agriculture scenario. The construction scenario also assumes external exposure to unshielded waste, whereas in the agriculture scenario shielding during indoor residence on the disposal site is taken into account.

From its definition, the construction scenario would occur at the same time as the agriculture scenario. Therefore, the dose analysis for the two scenarios would be based on the same concentrations of radionuclides. Previous calculations (Kennedy and Peloquin 1988) provide a direct comparison of doses for the two scenarios. For a few radionuclides, the dose per unit concentration could be slightly higher for the construction scenario but, for most radionuclides, the dose per unit concentration is expected to be much greater for the agriculture scenario. This result assumes a reasonable exposure time for the construction scenario and the use of a reasonably consistent set of assumptions for the exposure pathways in the two scenarios. Therefore, since the dose limit for the acute construction scenario is a factor of 5 higher than the dose limit for the chronic agriculture scenario, the agriculture scenario always will be more restrictive and the construction scenario can be neglected.

\subsection{Discovery Scenario}

As in the resident scenario described in Sect. 4.6.1.1.2, the discovery scenario assumes that an intruder attempts to dig into a disposal facility while excavating a foundation for a home on the disposal site, but encounters an intact concrete roof or other engineered barrier which cannot easily be penetrated by the types of excavating equipment that normally would be used at the SRS. However, in distinction from the resident scenario, the intruder soon decides to abandon digging at that location and moves elsewhere. Since intact engineered barriers are assumed not to be breached during excavation, the primary exposure pathway for this scenario is external exposure to photonemitting radionuclides in the disposal facility during the time the intruder digs at the site and the barriers are uncovered. The presence of intact barriers is assumed to preclude any significant inhalation or ingestion exposures.

From its definition, the discovery scenario would occur at the same time as the resident scenario. Furthermore, the relevant exposure pathway, which is external exposure to photon-emitting radionuclides in the waste, is essentially the same in the discovery and resident scenarios. Other than the exposure time, the only difference is the shielding factor during indoor residence, which is relevant only for the resident scenario. Therefore, since the exposure time for the discovery scenario presumably would be no more than $100 \mathrm{~h}$ (ORNL 1990), which is considerably less than a reasonable exposure time for indoor residence in the resident scenario, and the dose limit for the discovery scenario is a factor of 5 greater than the dose limit for the resident scenario, the resident scenario always will be more restrictive and the discovery scenario can be neglected. 


\subsection{Drilling Scenario}

The chronic post-drilling scenario described in Sect. 4.6.1.1.4 is based on the assumption that an intruder drills a well directly through a disposal unit. The acute drilling scenario considers exposures during the short period of time for drilling and construction of the well.

During well drilling and construction, the most important exposure pathway is assumed to be external exposure to uncovered drilling wastes confined to a pile near the well. Although some radionuclides in the drilling waste could be suspended into the air and inhaled during well drilling and construction, inhalation exposures are expected to be relatively unimportant due to such factors as the initial water content of the drilling wastes, the small volume of the waste produced, and the absence of direct mechanical disturbance of the waste pile. Ingestion exposure also is assumed to be unimportant during normal drilling activities. The potential importance of the drilling scenario arises primarily from the assumption that an intruder could be located near an unshielded waste pile for a substantial period of time.

From its definition, the drilling scenario would occur at the same time as the post-drilling scenario. Therefore, the dose analyses for the two scenarios would be based on the same concentrations of radionuclides. Previous calculations (Kennedy and Peloquin 1988) provide a direct comparison of doses for the two scenarios. For all radionuclides, the dose per unit concentration for the drilling scenario is expected to be at least an order of magnitude less than the dose per unit concentration for the post-drilling scenario, provided a reasonable exposure time for the drilling scenario and a reasonably consistent set of assumptions for the exposure pathways in the two scenarios are used. Therefore, the post-drilling scenario always will be more restrictive and the drilling scenario can be neglected.

\subsection{Summary of Acute Exposure Scenarios}

In this section, three scenarios for acute exposure of inadvertent intruders were discussed, i.e., the construction, discovery, and drilling scenarios. However, an evaluation of these scenarios has shown that all three scenarios can be neglected because the chronic agriculture, resident, and post-drilling scenarios will always be more restrictive.

\subsubsection{Summary of Exposure Scenarios for Inadvertent Intruders}

Several chronic and acute exposure scenarios for inadvertent intruders have been considered for use in this preliminary PA. However, on the basis of previous analyses and considerations of how these scenarios would apply to the E-Area LLWF, it is evident that only the following three chronic exposure scenarios need to be included:

- an agriculture scenario involving direct intrusion into disposal units at times after the engineered barriers above the waste have lost their structural and physical integrity and can be penetrated by the types of excavation procedures normally used at the SRS;

- a resident scenario involving permanent residence in a home located on top of an intact ILTV, which first could occur at 100 years after facility closure, or on top of intact but essentially exposed waste at times after the engineered barriers have lost their integrity; and

- a post-drilling scenario involving exhumation of waste from a disposal unit at times after drilling through a disposal unit becomes credible.

Estimates of dose for all of these scenarios are considered in this preliminary PA. All acute exposure scenarios would be less restrictive in regard to demonstrating compliance with the performance objective for protection of inadvertent intruders and, thus, are not considered further in this analysis.

\subsubsection{Screening Of Radionuclides for Intruder Dose Analysis}

Many radionuclides decay significantly before an inadvertent intruder may come into contact with them according to the exposure scenarios described in Sect. 4.6.1. For these radionuclides, calculated allowable inventories greatly exceed any imaginable inventory in a disposal unit of the E-Area LLWF. Screening calculations were therefore carried out to eliminate radionuclides that are negligible contributors to dose from further analysis ${ }^{12}$.

\subsubsection{Dose To Inadvertent Intruders}

The discussion of possible exposure scenarios for inadvertent intruders in Sect. 4.6.1 shows that only three scenarios need be considered in the analysis for the E-Area LLWF. All of these scenarios involve chronic exposure and, thus, are subject to a limit on EDE from all exposure pathways of $100 \mathrm{mrem}$ per year. The discussion in Sect. 4.6.1 shows that other scenarios involving chronic or acute exposure either are not credible for the E-Area LLWF, would result in lower doses than the scenarios considered in the analysis, or are subject to a higher dose limit in the case of acute 
exposure scenarios (i.e., $500 \mathrm{mrem}$ ) and, thus, would be less restrictive than the chronic exposure scenarios considered in the analysis.

The models for estimating dose for the three chronic exposure scenarios for inadvertent intruders considered in this analysis are presented in the LLWF PA ${ }^{3}$. The inputs to the model for each scenario are the concentrations of radionuclides in the disposal facility at any time after the scenario is first assumed to be credible. The concentrations of radionuclides in disposal units over time are estimated using the initial concentrations at disposal corrected for radioactive decay. Ingrowth of radiologically significant decay products at times long after disposal is potentially important in the intruder dose analysis, and is accounted for in the analysis. The results of implementing models for the agriculture, resident, and post-drilling scenarios for a unit concentration in waste are summarized in Table 4.6.3. For each radionuclide. and exposure scenario, the scenario dose conversion factor (SDCF) gives the EDE in rem per year for a unit concentration in the disposal facility of $1 \mu \mathrm{Ci} / \mathrm{m}^{3}$.

For an assumed exposure scenario and particular type of disposal unit, the EDE (rem/year) to an inadvertent intruder from exposure to a given radionuclide can be expressed as

$H=\left(I_{0} / V\right) * S D C F * G * F$

where

$$
\begin{array}{lll}
H & = & \text { EDE (rem/year) } \\
I D & = & \text { inventory of radionuclide in disposal units at time of disposal }(\mu \mathrm{Ci}), \\
V & = & \text { volume of waste in disposal units }\left(\mathrm{m}^{3}\right), \\
S D C F & = & \text { scenario dose conversion factor for radionuclide }\left(\mathrm{rem} / \mathrm{year} \text { per } \mu \mathrm{Ci} / \mathrm{m}^{3}\right), \\
G & = & \text { geometrical correction factor (dimensionless), and } \\
F & = & \text { fraction of initial inventory of radionuclide remaining in disposal unit at time } \\
\text { intrusion occurs. }
\end{array}
$$

The correction factors $G$ and $F$ take into account the fact that the average radionuclide concentration encountered by an inadvertent intruder would be less than the initial average concentration in disposed waste and that the dose would be correspondingly reduced.

The geometrical correction factor, $G$, in Eq. 4.6.3-1 takes into account that a large-scale excavation into disposal units, as assumed in the agriculture and resident scenarios, would involve exposure to uncontaminated material between individual disposal units as well as disposed waste itself. This correction factor assumes, in essence, that excavation into disposal units would occur at random locations. Therefore, the geometrical correction factor is given by the fraction of the land area encompassed by the disposal unit. The geometrical correction factor for the ILTV is $0.4^{3}$. For the post-drilling scenario, the geometrical correction factor is assumed to be unity, because an intruder is assumed to drill only through contaminated regions in the disposal unit. Any uncontaminated material above and below the waste that also would be exhumed by drilling is taken into account in estimating the SDCF for the post-drilling scenario.

The parameter $F$ in Eq. 4.6.3-1 takes into account that, between the time of disposal and the time that a scenario for inadvertent intrusion is assumed to occur, the initial inventories of radionuclides in the disposal units would be reduced by radioactive decay.

\subsubsection{Dose Analysis for Agriculture Scenario}

This section discusses the results of applying the model for the intruder-agriculture scenario ${ }^{3}$ to the disposal of APT and TEF wastes in the ILTV.

Because of the design of the ILTV, the agriculture scenario involving direct excavation into the waste is not expected to become credible for a considerable period of time after disposal. Since the waste will be located well below the ground surface, a considerable amount of erosion will need to occur before the waste could be accessed by normal excavation procedures for a home. Then, the concrete roof and layer of uncontaminated grout above the waste are expected to preclude excavation into the waste for as long as they maintain their physical integrity.

An analysis ${ }^{3}$ of the expected performance of the earthen cover above the ILTV and the concrete roof and layers of grout in the vaults indicates that excavation into the waste is not credible for at least 20,000 years after disposal. The SDCFs for the radionuclides of concern are given in Table 4.6.3-1. The geometrical reduction factor for the ILTV is 0.4. The results of the dose analysis for the agriculture scenario are given in Table 4.6.3-2. The results are presented as the limit on inventory so as not to exceed the performance objective of $100 \mathrm{mrem} / \mathrm{year}$. 
Table 4,6.3-1 Intruder Scenario Dose Conversion Factors

\begin{tabular}{|c|c|c|c|}
\hline & Agriculture & Resident & Post-drilling \\
\hline Radionuclide & $\mathrm{rem} /$ year per $\mu \mathrm{Ci} / \mathrm{m}^{3}$ & $\mathrm{rem} /$ year per $\mu \mathrm{Ci} / \mathrm{m}^{3}$ & rem/year per $\mu \mathrm{Ci} / \mathrm{m}^{3}$ \\
\hline $\mathrm{H}-3$ & $3.89 \mathrm{E}-06$ & $0.00 \mathrm{E}+01$ & $3.89 \mathrm{E}-07$ \\
\hline $\mathrm{C}-14$ & $1.51 \mathrm{E}-05$ & $0.00 \mathrm{E}+01$ & $1.51 \mathrm{E}-06$ \\
\hline Al-26 & $3.87 \mathrm{E}-03$ & $2.77 \mathrm{E}-06$ & $1.81 \mathrm{E}-06$ \\
\hline Si-32 & $4.84 \mathrm{E}-07$ & $0.00 \mathrm{E}+01$ & $4.47 \mathrm{E}-08$ \\
\hline Cl-36 & $7.72 \mathrm{E}-04$ & $0.00 \mathrm{E}+0 \mathrm{I}$ & $7.71 \mathrm{E}-05$ \\
\hline $\mathrm{Ca}-41$ & $7.72 \mathrm{E}-06$ & $0.00 \mathrm{E}+01$ & $7.72 \mathrm{E}-0 \overline{7}$ \\
\hline Ti-44 & $7.81 \mathrm{E}-05$ & $4.20 \mathrm{E}-07$ & $1.09 \mathrm{E}-07$ \\
\hline $\mathrm{Mn}-53$ & $3.82 \mathrm{E}-07$ & $0.00 \mathrm{E}+01$ & $3.82 \mathrm{E}-08$ \\
\hline $\mathrm{Fe}-60$ & $2.75 \mathrm{E}-06$ & $0.00 \mathrm{E}+0 \mathrm{I}$ & $2.72 \mathrm{E}-07$ \\
\hline Co-60 & $3.52 \mathrm{E}-03$ & $1.16 \mathrm{E}-06$ & $1.81 \mathrm{E}-06$ \\
\hline $\mathrm{Ni}-59$ & $6.80 \mathrm{E}-08$ & $0.00 \overline{\mathrm{E}}+0 \mathrm{l}$ & $6 . \overline{79 E-09}$ \\
\hline $\mathrm{Ni}-63$ & $1.83 \mathrm{E}-07$ & $0.00 \mathrm{E}+01$ & $1.83 \mathrm{E}-08$ \\
\hline Se-79 & $1.22 \mathrm{E}-06$ & $0.00 \mathrm{E}+01$ & $1.22 \mathrm{E}-07$ \\
\hline Sr-90 & $1.90 \mathrm{E}-04$ & $0.00 \mathrm{E}+01$ & $1.85 \mathrm{E}-05$ \\
\hline $\mathrm{Nb}-93 \mathrm{~m}$ & $4.14 \mathrm{E}-08$ & $0.00 \mathrm{E}+01$ & $1.78 \mathrm{E}-09$ \\
\hline $\mathrm{Nb}-94$ & $2.11 \mathrm{E}-03$ & $1.40 \mathrm{E}-07$ & $1.08 \mathrm{E}-06$ \\
\hline Mo-93 & $1.81 \mathrm{E}-06$ & $0.00 \mathrm{E}+01$ & $1.68 \mathrm{E}-07$ \\
\hline Tc-97 & $1.43 \mathrm{E}-06$ & $0.00 \mathrm{E}+01$ & $1.26 \mathrm{E}-07$ \\
\hline Tc-98 & $1.94 \mathrm{E}-03$ & $7.00 \mathrm{E}-08$ & $4.95 \mathrm{E}-06$ \\
\hline Tc-99 & $1.09 \mathrm{E}-05$ & $0.00 \mathrm{E}+01$ & $1.09 \mathrm{E}-06$ \\
\hline Pd-107 & $3.17 \mathrm{E}-08$ & $0.00 \mathrm{E}+01$ & $3.14 \mathrm{E}-09$ \\
\hline $\mathrm{Ag}-108 \mathrm{~m}$ & $3.86 \mathrm{E}-03$ & $5.60 \mathrm{E}-08$ & $1.12 \mathrm{E}-06$ \\
\hline $\mathrm{Cd}-113$ & $1.03 \mathrm{E}-03$ & $0.00 \mathrm{E}+01$ & $1.03 \mathrm{E}-04$ \\
\hline $\ln -115$ & $6.33 \mathrm{E}-06$ & $0.00 \mathrm{E}+01$ & $6.14 \mathrm{E}-07$ \\
\hline $\mathrm{Sn}-121 \mathrm{~m}$ & $5.30 \mathrm{E}-08$ & $0.00 \mathrm{E}+01$ & $5.27 \mathrm{E}-09$ \\
\hline Sn-126 & $2.63 \mathrm{E}-03$ & $8.41 E-08$ & $3.05 \mathrm{E}-06$ \\
\hline $\mathrm{Te}-123$ & $5.29 \mathrm{E}-06$ & $0.00 \mathrm{E}+01$ & $5.29 \mathrm{E}-07$ \\
\hline Cs- 137 & $7.74 \mathrm{E}-04$ & $2.19 \mathrm{E}-08$ & $1.24 \mathrm{E}-06$ \\
\hline $\mathrm{Ba}-133$ & $4.23 \mathrm{E}-04$ & $7.70 \mathrm{E}-10$ & $2.83 \mathrm{E}-07$ \\
\hline La-137 & $3.11 \mathrm{E}-06$ & $0.00 \mathrm{E}+01$ & $3.10 \mathrm{E}-09$ \\
\hline $\mathrm{Pm}-145$ & $6.35 \mathrm{E}-06$ & $0.00 \mathrm{E}+01$ & $5.03 \mathrm{E}-09$ \\
\hline Sm-146 & $8.52 \mathrm{E}-06$ & $0.00 \mathrm{E}+01$ & $6.29 \mathrm{E}-07$ \\
\hline Sm-151 & $1.03 \mathrm{E}-08$ & $0.00 \mathrm{E}+01$ & $9.26 \mathrm{E}-10$ \\
\hline Eu-150 & $1.90 \mathrm{E}-03$ & $3.85 \mathrm{E}-09$ & $9.97 \mathrm{E}-07$ \\
\hline Eu-152 & $1.55 \mathrm{E}-03$ & 3.47E-07 & $7.76 \mathrm{E}-07$ \\
\hline Eu-154 & $1.69 \mathrm{E}-03$ & $3.50 \mathrm{E}-07$ & $8.45 \mathrm{E}-07$ \\
\hline Gd-148 & $1.63 \mathrm{E}-05$ & $0.00 \mathrm{E}+01$ & $6.89 \mathrm{E}-07$ \\
\hline Tb-157 & 6.37E-07 & $0.00 \mathrm{E}+01$ & $6.71 \mathrm{E}-10$ \\
\hline Tb-158 & $1.06 \mathrm{E}-03$ & $7.00 \mathrm{E}-08$ & $5.32 \mathrm{E}-07$ \\
\hline Ho- $166 \mathrm{~m}$ & $2.25 \mathrm{E}-03$ & $1.02 \mathrm{E}-07$ & $1.16 \mathrm{E}-06$ \\
\hline Hf- $178 \mathrm{~m}$ & $2.85 \mathrm{E}-03$ & $4.55 \mathrm{E}-09$ & $1.59 \mathrm{E}-06$ \\
\hline Hf- 182 & $2.75 \mathrm{E}-04$ & $5.95 \mathrm{E}-07$ & $2.28 \mathrm{E}-07$ \\
\hline Pt-193 & $1.43 \mathrm{E}-07$ & $0.00 \mathrm{E}+01$ & $1.42 \mathrm{E}-08$ \\
\hline $\mathrm{Pb}-202$ & $6.08 \mathrm{E}-06$ & $1.82 \mathrm{E}-08$ & $6.08 \mathrm{E}-07$ \\
\hline $\mathrm{Pb}-205$ & $8.67 \mathrm{E}-08$ & $0.00 \mathrm{E}+01$ & $8.51 \mathrm{E}-09$ \\
\hline Bi-207 & $2.08 \mathrm{E}-03$ & $3.85 \mathrm{E}-07$ & $1.65 \mathrm{E}-\overline{06}$ \\
\hline
\end{tabular}




\subsubsection{Dose Analysis for Resident Scenario}

Two bounding assumptions have been considered in the dose analysis for the resident scenario. In the first case, the intruder is assumed to reside in a home located immediately on top of the intact concrete vault roof, and the scenario is assumed to be credible immediately following assumed loss of active institutional control at 100 years after disposal. In the second case, the home is assumed to be located immediately on top of the waste in the disposal unit, but the scenario is assumed not to occur until the concrete roof and any other engineered barriers above the waste have lost their integrity and can be penetrated during excavation.

In both bounding cases for the resident scenario, the intruder is assumed not to excavate into the waste itself while constructing a home on the disposal site. Thus, the only exposure pathway of concern for this scenario is external exposure to photon-emitting radionuclides in the waste while residing in the home. The only differences between the two bounding cases are the time at which the scenario is assumed to become credible, as described above, and the amount of shielding between waste and the receptor location.

For the ILTV, however, the second case would not be credible at any time between the assumed loss of institutional control at 100 years and the time at which the agriculture scenario becomes credible (i.e., 20,000 years after disposal). Once the agriculture scenario becomes credible, the resident exposure becomes irrelevant because the agriculture scenario includes the resident scenario. Thus, the resident scenario is only evaluated at 100 years after disposal.

The ILTV will be constructed with a concrete roof of average thickness about $90 \mathrm{~cm}$ and a layer of uncontaminated grout above the waste of thickness about $90 \mathrm{~cm}$. Thus, the total thickness of the engineered barriers is about $1.8 \mathrm{~m}$, and this thickness of shielding would apply to the resident scenario for the ILTV at 100 years after disposal when all engineered barriers are assumed to be intact and impenetrable by normal excavation procedures.

The 1.8-m thickness of shielding in the ILTV is sufficient to reduce the external dose to very low levels for any conceivable concentrations of photon-emitting radionuclides in the waste ${ }^{3}$. Therefore, in the dose analysis for the ILTV at 100 years after disposal, the conservative assumption is made that only the layer of uncontaminated grout above the waste is present to provide shielding. For purposes of this analysis, the thickness of the grout layer is assumed to be $100 \mathrm{~cm}$. This value is slightly greater than the planned thickness and is intended to take into account the somewhat greater shielding provided by any metal waste containers and wasteforms in the ILTV compared with the shielding provided by soil-equivalent material.

The SDCFs obtained from the model for estimating dose to an inadvertent intruder for the resident scenario are given in Table 4.6.3-1. The geometrical reduction factor for the ILTV is 0.4 . The results of the dose analysis for the agriculture scenario are given in Table 4.6.3-2. The results are presented as the limit on inventory so as not to exceed the performance objective of $100 \mathrm{mrem} /$ year.

\subsubsection{Dose Analysis for Post-Drilling Scenario}

The post-drilling scenario is potentially relevant for any disposal unit for which drilling into the waste may occur before the agriculture scenario becomes credible. However, in the ILTV, the waste will be grouted, and drilling into the waste is not expected to be a credible occurrence until the grout essentially has weathered to soil-equivalent material, at which time the agriculture scenario becomes credible. Therefore, since the agriculture scenario always results in greater calculated dose than the post-drilling scenario when the two scenarios are assumed to occur at the same time, the post-drilling scenario need not be considered further. 
Table 4.6.3-2 Intruder Results

\begin{tabular}{|c|c|c|}
\hline Radionuclide & $\begin{array}{c}\text { Agriculture } \\
20,000 \text { years } \\
\text { Ci/vault }\end{array}$ & $\begin{array}{c}\text { Resident } \\
100 \text { years } \\
\mathrm{Ci} / \text { vault }\end{array}$ \\
\hline $\mathrm{H}-3$ & No Limit & No Limit \\
\hline C-14 & No Limit & No Limit \\
\hline Al-26 & No Limit & $5.15 E+02$ \\
\hline $\mathrm{Si}-32$ & No Limit & No Limit \\
\hline $\mathrm{Cl}-36$ & No Limit & No Limit \\
\hline $\mathrm{Ca}-41$ & $3.61 \mathrm{E}+13$ & No Limit \\
\hline$\overline{T i-44}$ & No Limit & $1 . \overline{47 \mathrm{E}+04}$ \\
\hline $\mathrm{Mn}-53$ & $2.02 E+07$ & No Limit \\
\hline $\mathrm{Fe}-60$ & No Limit & No Limit \\
\hline $\mathrm{Co}-60$ & No Limit & $6.17 \mathrm{E}+08$ \\
\hline Ni-59 & No Limit & No Limit \\
\hline $\mathrm{Ni}-63$ & $9.71 \mathrm{E}+23$ & No Limit \\
\hline Se-79 & $1.58 \mathrm{E}+63$ & No Limit \\
\hline $\mathrm{Sr}-90$ & No Limit & No Limit \\
\hline $\mathrm{Nb}-93 \mathrm{~m}$ & No Limit & No Limit \\
\hline $\mathrm{Nb}-94$ & $1.73 E+03$ & $1.02 E+04$ \\
\hline Mo-93 & No Limit & No Limit \\
\hline Tc-97 & $5.34 \mathrm{E}+10$ & No Limit \\
\hline Tc-98 & No Limit & $2.04 \mathrm{E}+04$ \\
\hline Tc-99 & No Limit & No Limit \\
\hline Pd-107 & $4.05 E+15$ & No Limit \\
\hline $\mathrm{Ag}-108 \mathrm{~m}$ & No Limit & $4.39 \mathrm{E}+04$ \\
\hline $\mathrm{Cd}-113$ & No Limit & No Limit \\
\hline In-115 & No Limit & No Limit \\
\hline $\mathrm{Sn}-12 \mathrm{~lm}$ & No Limit & No Limit \\
\hline $\mathrm{Sn}-126$ & $1.39 \mathrm{E}+00$ & $1 . \overline{70 E+04}$ \\
\hline $\mathrm{Te}-123$ & No Limit & No Limit \\
\hline Cs-137 & No Limit & $6.52 \mathrm{E}+05$ \\
\hline $\mathrm{Ba}-133$ & $2.89 E+60$ & $1.36 \mathrm{E}+09$ \\
\hline La-137 & No Limit & No Limit \\
\hline Pm-145 & No Limit & No Limit \\
\hline $\mathrm{Sm}-14 \overline{6}$ & No Limit & No Limit \\
\hline $\mathrm{Sm}-151$ & $3.81 E+38$ & No Limit \\
\hline Eu-150 & No Limit & $2.84 \mathrm{E}+06$ \\
\hline Eu-152 & No Limit & $7.25 \mathrm{E}+05$ \\
\hline Eu-154 & No Limit & $1.07 \mathrm{E}+07$ \\
\hline Gd-148 & No Limit & No Limit \\
\hline $\mathrm{Tb}-157$ & No Limit & No Limit \\
\hline $\mathrm{Tb}-158$ & No Limit & $2.16 \mathrm{E}+04$ \\
\hline Ho-166m & No Limit & $1 . \overline{49 E+04}$ \\
\hline Hf- $178 m$ & No Limit & No Limit \\
\hline Hf-182 & No Limit & $2.39 \bar{E}+03$ \\
\hline Pt-193 & $6.63 \mathrm{E}+05$ & No Limit \\
\hline $\mathrm{Pb}-202$ & No Limit & $7.83 \mathrm{E}+04$ \\
\hline $\mathrm{Pb}-205$ & $2.26 E+36$ & No Limit \\
\hline $\mathrm{Bi}-207$ & No Limit & $2.95 \mathrm{E}+04$ \\
\hline
\end{tabular}




\subsubsection{Sensitivity and Uncertainty in Dose Models for Inadvertent Intruders}

The generalized model for estimating dose to an inadvertent intruder, as represented by Eq. 4.6.3-1, is based on estimates of annual doses per unit concentration of radionuclides in disposed waste, the so-called SDCFs for the agriculture, and resident scenarios summarized in Table 4.6.3-1. In this section, the sensitivity and uncertainty. analyses of the models used to estimate the SDCFs for the different exposure scenarios for inadvertent intruders are discussed.

For each of the assumed exposure scenarios, the SDCFs for radionuclides are single values based on the models and parameter values presented in the LLWF PA. The parameter values adopted for use in models for the different exposure pathways usually were intended to represent reasonable average conditions that might be experienced, rather than maximum possible conditions that would yield the highest estimates of dose. This approach was used in selecting parameter values related to human activities, such as the annual consumption of foodstuffs, breathing rate, and exposure times, and parameter values describing transport of radionuclides through environmental pathways to man, such as the elemental plant-to-soil concentration ratios and atmospheric mass loading of activity suspended from surface soil.

The exposure pathways considered in the dose analyses for an inadvertent intruder for the different exposure scenarios include consumption of vegetables grown in contaminated garden soil, direct consumption of contaminated garden soil, external exposure while working in the garden or during indoor residence, and inhalation exposure while working in the garden or during indoor residence. In implementing the models for the various exposure pathways, data specific to the SRS generally were not available for such important parameters as the elemental plant-to-soil concentration ratios in vegetables grown in contaminated garden soil and the airborne concentration of suspended radionuclides in particulate form. Therefore, generic parameter values obtained from the literature were used in many of the exposure pathway models.

A list of parameters used in calculating SDCFs is provided in Table 4.6.4-1. The value assumed for each parameter, the exposure scenario to which each parameter is relevant, and comments pertinent to the choice of parameter value are given.

Parameters listed in Table 4.6.4-1 that are the focus of the following discussion include: 1) atmospheric mass loading of contaminated surface soil; 2) consumption of contaminated soil; 3) exposure times for working in a garden and residing in a home; and 4) plant-to-soil concentration factors. Other parameters listed in Table 4.6.4-1 are not a part of this discussion because they are either not considered as highly variable as the above-listed parameters (e.g., breathing rate of $8,000 \mathrm{~m}^{3} / \mathrm{yr}$; bulk density of soil of $1,400 \mathrm{~kg} / \mathrm{m}^{3}$; and shielding factor during indoor residence), and/or because their variability is not readily quantifiable. For parameters falling into this latter category (e.g., thicknesses of engineered barriers; annual consumption of $90 \mathrm{~kg}$ of home-grown vegetables; dilution factors for mixing exhumed or drilled waste into garden soil), conservative values were assumed that are likely to lead to overestimates of dose.

For radionuclides which do not emit significant intensities of high-energy photons (e.g., C-14, Sr-90 and Tc-99), the vegetable pathway is the only significant contributor to the total dose for the agriculture and post-drilling scenarios, and the dose for this pathway is directly proportional to the plant-to-soil concentration ratio. Data available in the literature, which often were obtained under conditions that may not be representative of the SRS, indicate that this parameter could be uncertain by as much as one-to-three orders of magnitude depending upon the radionuclide ( $\mathrm{Ng}$ et al. 1982; Peterson 1983).

The dose for the resident scenario is due entirely to external exposure; and, for radionuclides that emit significant intensities of high-energy photons (e.g., Sn-126 and Cs-137), this pathway is the only significant contributor to the total dose for the agriculture scenario. The dose from external exposure depends on the assumed exposure time and the amount of shielding between the source and receptor locations. Particularly in the resident scenario, estimates of external dose could be uncertain by an order of magnitude or more if the assumed thickness of shielding provided by engineered barriers is in error by only a few tens of $\mathrm{cm}$. The assumed thickness of shielding for the ILTV probably results in overestimates of dose. External dose in the resident and agriculture scenarios also depends on the shielding factor for the walls of the home during indoor residence, and the duration of residence throughout a year. The shielding factor for the walls probably is uncertain by no more than a factor of two, as is the amount of time spent inside a home.

For some important parameters in the exposure pathway models, it is difficult to quantify the uncertainty even on the basis of generic data. An example of a parameter for which the uncertainty appears to be essentially unquantifiable is the assumed dilution factor for mixing of waste exhumed from disposal units with native soil in a vegetable garden. The dose from several exposure pathways in the agriculture scenario is directly proportional to this dilution factor. An uncertainty analysis for this parameter could be based on estimated uncertainties in the volume of waste exhumed from disposal units, the fraction of exhumed waste that is mixed with soil in a vegetable garden, and the size of the garden. But, except for the assumed size of the garden, there are no data that could be used to support such an uncertainty analysis, essentially because the values are based primarily on assumptions presumed to be reasonable. The uncertainty in this dilution factor is probably an order of magnitude or more. 
However, it seems likely that the values chosen for use in this analysis tend to overestimate the average concentrations of radionuclides that would be found in contaminated soil in a vegetable garden. The dilution factor of 0.2 assumed in the agriculture scenario probably is conservative because exhumed waste presumably would not be fertile material and, thus, soil containing a significantly larger fraction of exhumed material would not support plant growth.

It is important to note that the most significant source of uncertainty in the estimates of the SDCFs for the different exposure scenarios probably is the definitions of the scenarios themselves, not withstanding any parameter uncertainties that could be quantified and regardless of whether or not the results would reasonably represent the variability in doses that could be experienced at the SRS. The dose analyses for inadvertent intruders are based on assumptions that the exposure scenarios will occur as postulated, but many of the explicit or implicit assumptions used in defining the scenarios are open to question and, furthermore, are likely to be conservative.

In defining exposure scenarios, it seems reasonable to assume that an inadvertent intruder will establish a homestead within the boundary of the disposal facility at some time after assumed loss of active institutional controls. However, several of the assumptions used in developing the particular exposure scenarios are less certain and probably pessimistic. For example, all scenarios assume that individuals will have no knowledge of prior waste disposal activities at the site, but this assumption seems unreasonable for times soon after loss of active institutional controls. Furthermore, even if knowledge of the disposal facility were lost, all exposure scenarios assume that an inadvertent intruder will build a home or drill a well at the location of disposal units, rather than in uncontaminated areas, and that exhumed waste will be mixed with uncontaminated soil in a vegetable garden. Particularly at the SRS, it may also be pessimistic to assume that an intruder would excavate to depths well below the ground surface in constructing a home, because most homes near the site do not have a basement.

By their very definitions, the exposure scenarios for inadvertent intruders assume conditions that probably tend to produce estimates of dose considerably greater than doses that reasonably could be received by most individuals who might come onto the disposal site. Quantitative estimates of uncertainties in calculated doses based on parameter uncertainty analyses may not be meaningful, because the results are conditional on the occurrence of the assumed exposure scenarios. The most important factor in determining whether or not the dose analyses for inadvertent intruders are likely to be reasonable is the credibility of the assumed exposure scenarios (i.e., whether the assumed exposure scenarios reasonably could occur at a particular disposal facility) rather than any estimates of uncertainties in the results due to uncertainties in model parameters. 


\begin{tabular}{|c|c|c|c|}
\hline \multicolumn{4}{|c|}{$\begin{array}{l}\text { Table 4.6.4-1 Parameters used in calculating SDCFs for Intruder dose analyses, by exposure } \\
\text { scenario }\end{array}$} \\
\hline Parameter description & Parameter value & $\begin{array}{l}\text { Exposure } \\
\text { scenario }\end{array}$ & Comments \\
\hline Air intake (breathing rate) & $8,000 \mathrm{~m}^{3} /$ year & Agriculture & Standard value \\
\hline $\begin{array}{l}\text { Atmospheric mass loading of } \\
\text { contaminated surface soil - } \\
\text { working in garden " } \\
\text { residing in home " }\end{array}$ & $\begin{array}{l}10^{-7} \mathrm{~kg} / \mathrm{m}^{3} \\
10^{-8} \mathrm{~kg} / \mathrm{m}^{3}\end{array}$ & Agriculture & $\begin{array}{l}\text { Value based on site- } \\
\text { specific and nonurban } \\
\text { U.S. data }\end{array}$ \\
\hline Consumption of contaminated soil & $0.037 \mathrm{~kg} /$ year & Agriculture & $\begin{array}{l}\text { EPA value - may vary } \\
\text { by at least an order of } \\
\text { magnitude }\end{array}$ \\
\hline Consumption of contaminated vegetables & $\begin{array}{l}90 \mathrm{~kg} \text { (fresh } \\
\text { weight) per } \\
\text { year }\end{array}$ & Agriculture & $\begin{array}{l}\text { Site-specific and } \\
\text { assumes } 1 / 2 \text { veg from } \\
\text { garden }\end{array}$ \\
\hline Density of soil when waste is mixed in & $1,400 \mathrm{~kg} / \mathrm{m}^{3}$ & All & $\begin{array}{l}\text { Reasonable, and in } \\
\text { agreement with site- } \\
\text { specific values }\end{array}$ \\
\hline $\begin{array}{l}\text { Dilution factor for mixing of exhumed } \\
\text { waste with native soil in vegetable garden }\end{array}$ & $0.2^{2}$ & Agriculture & $\begin{array}{l}\text { May vary by about l } \\
\text { order of magnitude; no } \\
\text { data to support, but } \\
\text { consistent with other } \\
\text { intruder analyses }\end{array}$ \\
\hline $\begin{array}{l}\text { Exposure times - } \\
\text { working in garden } \\
\text { residing in home }\end{array}$ & $\begin{array}{l}1 \% \text { per year } \\
50 \% \text { per year }\end{array}$ & All & $\begin{array}{l}\text { Reasonable, but could } \\
\text { vary for individuals }\end{array}$ \\
\hline Plant-to-soil concentration factors & $\begin{array}{l}\text { Element- } \\
\text { specific }\end{array}$ & Agriculture & $\begin{array}{l}\text { May be uncertain by as } \\
\text { much as one-to-three } \\
\text { orders of magnitude }\end{array}$ \\
\hline $\begin{array}{l}\text { Shielding factor for external exposure } \\
\text { during indoor residence }\end{array}$ & 0.7 & $\begin{array}{l}\text { Agriculture, } \\
\text { resident }\end{array}$ & $\begin{array}{l}\text { May be uncertain by } \\
\text { about a factor of two }\end{array}$ \\
\hline Thickness of engineered barriers & $100 \mathrm{~cm}$ & Resident & $\begin{array}{l}\text { May be uncertain by } \\
\text { several } \mathrm{cm} \text {, but value is } \\
\text { underestimated }\end{array}$ \\
\hline
\end{tabular}

2 Value of parameter applies to agriculture scenario for inadvertent intruders.

${ }^{b}$ Value of parameter applies to agriculture and resident scenarios for inadvertent intruders. 


\section{0}

INTERPRETATION OF RESULTS

This Section provides the interpretation of the results presented in Section 4.

\subsection{Groundwater Pathway}

The performance criteria that must be met were discussed in Section 2.3. Two criteria apply to the groundwater pathway. These are the $25 \mathrm{mrem} / \mathrm{year}$ "all pathways" criterion (Section 2.3.1) and the water resources protection criterion (Section 2.3.2). Previous analysis has shown that, at SRS, the water resources protection criterion is more restrictive than the all pathways criterion. Thus, the all pathways performance objective will not be discussed further.

The groundwater protection performance objective (Sect. 2.3.2) requires that the projected maximum groundwater concentration, within 10,000 years after disposal facility closure, must not exceed the maximum contaminant levels (MCL) specified by the Environmental Protection Agency". The projected maximum groundwater concentration for each radionuclide that is significant in the groundwater pathway is presented in Table 5.1-1. The values in the Table were obtained by multiplying the normalized concentration from Table 4.4-12 (either the normalized peak concentration or, if the peak occurs after 10,000 years, the normalized concentration at 10,000 years) by the total project inventory in Table 4.3-2. For the APT tungsten wasteform, the inventory of ${ }^{129} \mathrm{I},{ }^{127} \mathrm{La},{ }^{146} \mathrm{Sm}$, ${ }^{158} \mathrm{~Tb}$, and ${ }^{82} \mathrm{Hf}$ was reduced to $1 \%$ of the Table $4.3-2$ value to reflect that the tungsten is encased in inconel'

\begin{tabular}{|c|c|c|c|c|c|c|c|c|}
\hline \multirow[b]{3}{*}{ Radionuclide } & \multirow[b]{3}{*}{ MCL, $\mathrm{pCi} / \mathrm{L}$} & \multicolumn{5}{|c|}{ APT Waste } & \multicolumn{2}{|c|}{ TEF Waste } \\
\hline & & Tungsten & Window & Steel & Aluminum & Lead & TPBAR & Baseplate \\
\hline & & $\mathrm{pCi} / \mathrm{L}$ & $\mathrm{pCi} / \mathrm{L}$ & $\overline{\mathrm{pCi} / \mathrm{L}}$ & $\mathrm{pCi} / \mathrm{L}$ & $\mathrm{pCi} / \mathrm{L}$ & $\overline{\mathrm{pCi} / \mathrm{L}}$ & $\mathrm{pCi} / \mathrm{L}$ \\
\hline $\mathrm{Be}-10$ & $1.30 \mathrm{E}+03$ & $4.96 \mathrm{E}-04$ & $2.48 \mathrm{E}-05$ & $2.48 \mathrm{E}-05$ & $1.76 \mathrm{E}-02$ & $8.65 \mathrm{E}-02$ & & \\
\hline $\mathrm{C}-14$ & $6.40 \mathrm{E}+03$ & $3.64 \mathrm{E}-03$ & $1.04 \mathrm{E}-03$ & $1.04 \mathrm{E}-03$ & $2.14 \mathrm{E}-01$ & $5.32 \mathrm{E}+00$ & $2.06 \mathrm{E}+00$ & $1.30 \mathrm{E}-01$ \\
\hline Al-26 & $5.00 \mathrm{E}+01$ & $1.68 \mathrm{E}-08$ & $1.12 \mathrm{E}-09$ & $1.12 \mathrm{E}-09$ & $3.98 \mathrm{E}-06$ & $3.00 \mathrm{E}-06$ & & \\
\hline Si-32 & $3.22 \mathrm{E}+03$ & $2.04 \mathrm{E}-01$ & $2.72 E-06$ & $2.72 \mathrm{E}-06$ & $4.13 \mathrm{E}-08$ & $3.98 \mathrm{E}-05$ & & \\
\hline Cl-36 & $1.83 \mathrm{E}+03$ & $3.30 \mathrm{E}+01$ & $3.52 \mathrm{E}+00$ & $3.52 \mathrm{E}+00$ & $3.54 \mathrm{E}-09$ & $6.11 E+01$ & & \\
\hline $\mathrm{K}-40$ & $2.88 \mathrm{E}+02$ & $1.68 \mathrm{E}-02$ & $1.12 \mathrm{E}-03$ & $1.12 \mathrm{E}-03$ & $8.69 \mathrm{E}-08$ & $1.91 \mathrm{E}-01$ & & \\
\hline $\mathrm{Ca}-41$ & $4.57 \mathrm{E}+03$ & $2.16 \mathrm{E}+02$ & $1.44 \mathrm{E}+01$ & $1.44 \mathrm{E}+01$ & $5.26 \mathrm{E}+01$ & $2.58 \mathrm{E}+03$ & $1.37 \mathrm{E}+02$ & \\
\hline Mn-53 & $5.53 \mathrm{E}+04$ & $1.92 \mathrm{E}+00$ & $4.80 \mathrm{E}-02$ & $4.80 \mathrm{E}-02$ & $1.01 \mathrm{E}-09$ & $1.94 \mathrm{E}-01$ & & \\
\hline$\overline{\mathrm{Fe}}-60$ & $3.65 \mathrm{E}+01$ & $3.52 \mathrm{E}-04$ & $8.80 \mathrm{E}-06$ & $8.80 \mathrm{E}-06$ & $2.71 \mathrm{E}-08$ & $3.83 \mathrm{E}-03$ & & \\
\hline $\mathrm{Ni}-59$ & $5.30 \mathrm{E}+02$ & $3.44 \mathrm{E}-0 \mathrm{I}$ & $2.06 \mathrm{E}-03$ & $2.06 \mathrm{E}-03$ & $3.16 \mathrm{E}-03$ & $7.75 \mathrm{E}-06$ & $3.66 \mathrm{E}+00$ & $3.83 \mathrm{E}-01$ \\
\hline Se-79 & $1.10 \mathrm{E}+02$ & $3.46 \mathrm{E}-01$ & $3.84 \mathrm{E}-06$ & $3.84 \mathrm{E}-06$ & & $4.12 \mathrm{E}+01$ & & \\
\hline Zr-93 & $2.10 \mathrm{E}+03$ & $1.44 \mathrm{E}-13$ & $1.44 \mathrm{E}-15$ & $1.44 \mathrm{E}-15$ & & $1.70 \mathrm{E}-12$ & $2.94 \mathrm{E}-11$ & \\
\hline $\mathrm{Nb}-94$ & $7.07 \mathrm{E}+02$ & $1.00 \mathrm{E}+00$ & $2.00 \mathrm{E}-03$ & $2.00 \mathrm{E}-03$ & & $1.35 \mathrm{E}-01$ & $1.58 \mathrm{E}-01$ & $2.55 \mathrm{E}-03$ \\
\hline Mo-93 & $4.21 \mathrm{E}+03$ & $2.35 \mathrm{E}+03$ & $1.18 \mathrm{E}+01$ & $1.18 \mathrm{E}+01$ & & $3.61 \mathrm{E}+03$ & $1.18 \mathrm{E}+03$ & $2.97 \mathrm{E}+01$ \\
\hline Tc-99 & $8.00 \mathrm{E}+02$ & $1.80 \mathrm{E}+00$ & $1.80 \mathrm{E}-03$ & $1.80 \mathrm{E}-03$ & & $2.28 \mathrm{E}+00$ & $4.74 E+00$ & $3.50 \mathrm{E}-02$ \\
\hline $1-129$ & $5.00 \mathrm{E}-01$ & $2.00 \mathrm{E}-05$ & & & & $3.97 \mathrm{E}-01$ & & \\
\hline La-137 & $1.27 \mathrm{E}+04$ & $8.04 \mathrm{E}-11$ & & & & $4.07 \mathrm{E}-10$ & & \\
\hline $\mathrm{Sm}-146$ & $1.50 \mathrm{E}+01$ & $6.72 \mathrm{E}-12$ & & & & $3.04 \mathrm{E}-10$ & & \\
\hline Tb-158 & $1.25 \mathrm{E}+03$ & $1.28 \mathrm{E}-04$ & & & & $2.67 \mathrm{E}-02$ & & \\
\hline Ho-166m & $7.02 \mathrm{E}+02$ & $6.84 \mathrm{E}-10$ & & & & $8.90 \mathrm{E}-09$ & & \\
\hline Hf-182 & $3.91 \mathrm{E}+02$ & $2.64 \mathrm{E}-14$ & & & & $7.41 \mathrm{E}-15$ & & \\
\hline $\mathrm{Pb}-202$ & $1.40 \mathrm{E}+02$ & & & & & $1.17 \mathrm{E}+00$ & & \\
\hline $\mathrm{Pb}-205$ & $3.65 \mathrm{E}+03$ & & & & & $1.66 \mathrm{E}-02$ & & \\
\hline
\end{tabular}


The groundwater concentrations must be compared to the MCLs (Section 2.3.2). Table 5.1-1 also shows the relevant MCLs. The MCLs vary by radionuclide characteristic. For the radionuclides considered here, all but ${ }^{146} \mathrm{Sm}$ fall in the category of "man-made beta particle and photon emitting radionuclides" for which the MCL is based on a dose of 4 mrem per year from all of these radionuclides combined. The MCL for alpha-emitting radionuclides is 15 $\mathrm{pCi} / \mathrm{L}$.

The APT waste streams include low-level waste (i.e., Tungsten, Window, Steel, and Aluminum) as well as mixed waste (i.e., Lead). Even though SRS has no plans to develop disposal capability for mixed waste, the mixed waste Lead was evaluated based solely on its radionuclide content. In comparing the APT waste with the MCLs, the lowlevel waste streams are grouped together separately from the mixed waste Lead. Table 5.1-2 shows the ratio of the projected maximum groundwater cancentration to the MCL for each radionuclide. The APT and TEF low-level waste streams have been grouped together.

\begin{tabular}{|c|c|c|c|}
\hline $\begin{aligned} \text { Table 5.1-2 } & \begin{array}{l}\text { Ratio of Proje } \\
\text { Concentration }\end{array}\end{aligned}$ & $\begin{array}{l}\text { Maximum C } \\
\text { MCL }\end{array}$ & iroundwater & \\
\hline Radionuclide & APT LLW & TEF LLW & APT Lead \\
\hline $\mathrm{Be}-10$ & $1.39 \mathrm{E}-05$ & & $6.63 \mathrm{E}-05$ \\
\hline$C-14$ & $3.43 \mathrm{E}-05$ & $3.43 \mathrm{E}-04$ & $8.31 \mathrm{E}-04$ \\
\hline Al-26 & $8.01 \mathrm{E}-08$ & & $6.00 \mathrm{E}-08$ \\
\hline $\mathrm{Si}-32$ & $6.33 \mathrm{E}-05$ & & $1.23 \mathrm{E}-08$ \\
\hline$\overline{C l}-36$ & $2.19 \mathrm{E}-02$ & & $3.35 \mathrm{E}-02$ \\
\hline $\mathrm{K}-40$ & $6.60 \mathrm{E}-05$ & & $6.61 \mathrm{E}-04$ \\
\hline $\mathrm{Ca}-41$ & $6.51 \mathrm{E}-02$ & $3.00 \mathrm{E}-02$ & $5.65 \mathrm{E}-01$ \\
\hline Mn-53 & $3.64 \mathrm{E}-05$ & & $3.50 \mathrm{E}-06$ \\
\hline $\mathrm{Fe}-60$ & $1.01 \mathrm{E}-05$ & & $1.05 \mathrm{E}-04$ \\
\hline Ni-59 & $6.63 \mathrm{E}-04$ & $7.62 \mathrm{E}-03$ & $1.46 \mathrm{E}-08$ \\
\hline Se-79 & $3.14 \mathrm{E}-03$ & & $3.75 \mathrm{E}-0 \mathrm{I}$ \\
\hline Zr-93 & $6.99 \mathrm{E}-17$ & $1.40 \mathrm{E}-14$ & $8.10 \mathrm{E}-16$ \\
\hline $\mathrm{Nb}-94$ & $1.42 \mathrm{E}-03$ & $2.27 \mathrm{E}-04$ & $1.90 \mathrm{E}-04$ \\
\hline Mo-93 & $5.64 \mathrm{E}-01$ & $2.88 \mathrm{E}-01$ & $8.57 \mathrm{E}-01$ \\
\hline Tc-99 & $2.25 \mathrm{E}-03$ & $5.97 \mathrm{E}-03$ & $2.85 \mathrm{E}-03$ \\
\hline I-129 & $4.00 \mathrm{E}-05$ & & $7.95 \mathrm{E}-01$ \\
\hline La-137 & $6.31 \mathrm{E}-15$ & & $3.20 \mathrm{E}-14$ \\
\hline Sm-146 & $4.48 \mathrm{E}-13$ & & $2.03 \mathrm{E}-11$ \\
\hline $\mathrm{Tb}-158$ & $1.02 \mathrm{E}-07$ & & $2.14 \mathrm{E}-05$ \\
\hline Ho-166m & $9.74 \mathrm{E}-13$ & & $1.27 \mathrm{E}-11$ \\
\hline Hf-182 & $6.75 \mathrm{E}-17$ & & $1.89 \mathrm{E}-17$ \\
\hline $\mathrm{Pb}-202$ & & & $8.29 \mathrm{E}-03$ \\
\hline $\mathrm{Pb}-205$ & & & $4.55 \mathrm{E}-06$ \\
\hline $\begin{array}{l}\text { Sum of Fractions for beta- } \\
\text { gamma radionuclides }\end{array}$ & $6.58 \mathrm{E}-01$ & $3.32 \mathrm{E}-01$ & $2.64 \mathrm{E}+00$ \\
\hline
\end{tabular}

The sum of fractions for the APT and TEF low-level waste streams are less than one, indicating that these wastes are suitable for disposal in the SRS LLWF Intermediate level vaults.

The sum of fractions for the APT mixed waste stream exceeds one; thus, based on the results of this preliminary PA, it is not suitable for disposal at SRS. However, considering the conservatism in the analysis, further work, if desired, is likely to show that this waste is also suitable for disposal at SRS.

\footnotetext{
'Samarium-146 is an alpha-emitting radionuclide. Thus, it is not included in the grouping of beta-gamma radionuclides.
} 


\subsection{Air Pathway}

The air pathway analysis is presented in Section 4.5. The results of the air pathway analysis are summarized in Table 4.5-11. The combined air dose from the TEF LLW is $0.0025 \mathrm{mrem} /$ year. The dose is dominated by the dose from ${ }^{14} \mathrm{C}$ at the E-Area boundary after 100 years of institutional control. The total dose is less than the performance objective of $10 \mathrm{mrem} /$ year. Thus, from the perspective of the air pathway, the TEF LLW is acceptable for disposal in the SRS LLWF.

The combined air dose from the APT LLW (i.e., tungsten, window, steel and aluminum, combined) is 7.7 mrem per year. The dose is essentially all from ${ }^{14} \mathrm{C}$ and ${ }^{36} \mathrm{Cl}$. The assumption that all of these isotopes are released in a gaseous phase is undoubtedly very conservative. Nonetheless, since the calculated dose is less than the performance objective of $10 \mathrm{mrem} /$ year, the APT LLW is acceptable for disposal in the SRS LLWF. However, further work to determine the fate of ${ }^{14} \mathrm{C}$ and ${ }^{36} \mathrm{Cl}$ released from the APT waste into the Intermediate Level Vault will likely be necessary to ensure compliance for the air pathway.

The calculated dose from the APT mixed-waste lead wasteform is 22 mrem/year. Since the dose is greater than the $10 \mathrm{mrem} /$ year performance objective, the APT mixed-waste lead, based on this preliminary performance assessment, is not suitable for disposal at SRS (based solely on its radionuclide content). However, the assumption that all of the ${ }^{14} \mathrm{C}$ and ${ }^{36} \mathrm{Cl}$ is released to the air is undoubtedly very conservative. Further work, if warranted, is likely to show the APT mixed-waste lead to be acceptable for disposal at the SRS LLWF, from the perspective of the air pathway.

\subsection{Inadvertent Intruder}

The performance objective for protection of persons who may inadvertently intrude onto the LLWF requires that the calculated dose to an inadvertent intruder not exceed 100 mrem per year for chronic exposures. The calculated dose should also not exceed 500 mrem for a single acute exposure (Sect. 2.3.3). As shown in Section 4.6.1, the chronic scenarios are more restrictive than acute scenarios.

The results of the intruder scenario calculations are presented in Table 4.6.3-2. The results are presented in the form of radionuclide inventory limits (i.e., curies per vault). If the expected radionuclide inventory exceeds the calculated limit, disposal of that inventory would result in exceedance of the performance objective. Thus, those APT or TEF wasteforms whose inventory for a particular radionuclide exceeds the calculated limits are not suitable for disposal in the LLWF.

Table 5.3-1 compares the radionuclide inventory (Table 4.3-2) to the calculated intruder limits (Table 4.6.3-2). In the table, ratio values are missing when there is no calculated limit for a radionuclide or when the inventory for a particular radionuclide is zero. 


\begin{tabular}{|c|c|c|c|c|c|c|}
\hline \multirow[b]{2}{*}{ Radionuclide } & \multicolumn{2}{|c|}{ APT LLW } & \multicolumn{2}{|c|}{ TEF LLW } & \multicolumn{2}{|c|}{ APT Lead } \\
\hline & Agriculture & Resident & Agriculture & Resident & Agriculture & Resident \\
\hline \multicolumn{7}{|l|}{$\mathrm{H}-3$} \\
\hline \multicolumn{7}{|l|}{$\mathrm{C}-14$} \\
\hline $\mathrm{Al}-26$ & & $5.55 \mathrm{E}-01$ & & & & $4.16 \mathrm{E}-01$ \\
\hline \multicolumn{7}{|l|}{ Si-32 } \\
\hline $\mathrm{Cl}-36$ & $3.78 \mathrm{E}-174$ & & & & $5.77 \mathrm{E}-174$ & \\
\hline $\mathrm{Ca}-41$ & $4.57 \mathrm{E}-13$ & & $2.11 \mathrm{E}-13$ & & $3.97 \mathrm{E}-12$ & \\
\hline Ti-44 & & $1.69 \mathrm{E}-01$ & & & & \\
\hline $\mathrm{Mn}-53$ & $8.30 \mathrm{E}-08$ & & & & $7.98 \mathrm{E}-09$ & \\
\hline \multicolumn{7}{|l|}{$\mathrm{Fe}-60$} \\
\hline $\mathrm{Co}-60$ & & $1: 95 \mathrm{E}-03$ & & $1.06 \mathrm{E}-02$ & & $2.64 \mathrm{E}-05$ \\
\hline \multicolumn{7}{|l|}{$\mathrm{Ni}-59$} \\
\hline $\mathrm{Ni}-63$ & $2.72 \mathrm{E}-21$ & & $7.59 \mathrm{E}-19$ & & $1.46 \mathrm{E}-20$ & \\
\hline Se-79 & $2.28 \mathrm{E}-64$ & & & & $2.72 \mathrm{E}-62$ & \\
\hline \multicolumn{7}{|l|}{ Sr-90 } \\
\hline $\mathrm{Nb}-93 \mathrm{~m}$ & $2.19 \mathrm{E}-243$ & & $2.04 \mathrm{E}-248$ & & $8.14 \mathrm{E}-246$ & \\
\hline Nb-94 & $2.33 \mathrm{E}-01$ & $3.93 \mathrm{E}-02$ & $3.72 \mathrm{E}-02$ & $6.28 \mathrm{E}-03$ & $3.12 \mathrm{E}-02$ & $5.27 \mathrm{E}-03$ \\
\hline Mo-93 & $1.92 \mathrm{E}-244$ & & $9.80 \mathrm{E}-245$ & & $2.92 \mathrm{E}-244$ & \\
\hline Tc-97 & $4.49 \mathrm{E}-12$ & & & & $8.19 \mathrm{E}-12$ & \\
\hline Tc-98 & $9.53 \mathrm{E}-150$ & $1.57 \mathrm{E}-06$ & & & $4.89 \mathrm{E}-149$ & $8.06 \mathrm{E}-06$ \\
\hline \multicolumn{7}{|l|}{ Tc-99 } \\
\hline Pd-107 & $3.95 \mathrm{E}-18$ & & & & $8.97 \mathrm{E}-17$ & \\
\hline $\mathrm{Ag}-108 \mathrm{~m}$ & & $6.38 \mathrm{E}-05$ & & & & $1.35 \mathrm{E}-04$ \\
\hline \multicolumn{7}{|l|}{$\mathrm{Cd}-113$} \\
\hline \multicolumn{7}{|l|}{ In-115 } \\
\hline Sn-121m & $2.95 \mathrm{E}-83$ & & $9.95 \mathrm{E}-81$ & & $8.18 \mathrm{E}-80$ & \\
\hline Sn-126 & $1.15 \mathrm{E}-14$ & $9.44 \mathrm{E}-19$ & & & $2.92 \mathrm{E}-05$ & $2.40 \mathrm{E}-09$ \\
\hline \multicolumn{7}{|l|}{$\mathrm{Te}-123$} \\
\hline Cs-137 & $2.69 \mathrm{E}-203$ & $2.45 \mathrm{E}-09$ & & & $8.29 \mathrm{E}-200$ & $7.55 \mathrm{E}-06$ \\
\hline $\mathrm{Ba}-133$ & $4.16 \mathrm{E}-56$ & $8.81 \mathrm{E}-05$ & $2.56 \mathrm{E}-59$ & $5.43 \mathrm{E}-08$ & $1.35 \mathrm{E}-56$ & $2.85 \mathrm{E}-05$ \\
\hline \multicolumn{7}{|l|}{ La-137 } \\
\hline Pm-145 & $2.16 \mathrm{E}-232$ & & & & $2.42 \mathrm{E}-233$ & \\
\hline \multicolumn{7}{|l|}{ Sm-146 } \\
\hline Sm-151 & $4.19 \mathrm{E}-37$ & & & & $5.96 \mathrm{E}-36$ & \\
\hline$\overline{\mathrm{Eu}-150}$ & $0.00 \mathrm{E}+01$ & & & & & \\
\hline Eu-152 & $0.00 \mathrm{E}+01$ & & & & $8.38 \mathrm{E}-222$ & $4.25 \mathrm{E}-03$ \\
\hline Eu-154 & & $2.24 \mathrm{E}-04$ & & & & $1.10 \mathrm{E}-03$ \\
\hline \multicolumn{7}{|l|}{ Gd-148 } \\
\hline Tb-157 & $7.20 \mathrm{E}-78$ & & & & $2.73 \mathrm{E}-78$ & \\
\hline Tb-158 & & $1.85 \mathrm{E}-01$ & & & & $3.87 \mathrm{E}-01$ \\
\hline Ho-166m & & 8.07E-04 & & & & $1.05 \mathrm{E}-02$ \\
\hline \multicolumn{7}{|l|}{$\mathrm{Hf}-178 \mathrm{~m}$} \\
\hline Hf- 182 & & $5.01 \mathrm{E}-05$ & & & & $1.41 \mathrm{E}-07$ \\
\hline Pt-193 & $2.41 \mathrm{E}-11$ & & & & $2.68 \mathrm{E}+00$ & \\
\hline $\mathrm{Pb}-202$ & & & & & & $1.06 \mathrm{E}-01$ \\
\hline $\mathrm{Pb}-205$ & & & & & $4.91 \mathrm{E}-35$ & \\
\hline $\mathrm{Bi}-207$ & & & & & $1.46 \mathrm{E}-116$ & $1.36 \mathrm{E}+01$ \\
\hline Total & $2.33 \mathrm{E}-01$ & $9.52 \mathrm{E}-01$ & $3.72 \mathrm{E}-02$ & $1.69 \mathrm{E}-02$ & $2.71 \mathrm{E}+00$ & $1.45 \mathrm{E}+01$ \\
\hline
\end{tabular}


The sum of the ratios for each radionuclide is also given in the table. When the sum of the ratios is less than one, the wasteform, in the aggregate of radionuclides, does not exceed the performance objective and is suitable for disposal in the LLWF.

The sum of the ratios for the TEF low-level waste is less than four percent of the intruder limits. Thus, the TEF LLW is suitable for disposal in the LLWF, based on this preliminary PA.

The sum of the ratios for the APT LLW is less than one. Thus, the APT LLW is suitable for disposal in the LLWF, based on this preliminary PA. Because the sum of the ratios is nearly one, further analysis, or a restriction of the APT waste to the lower layers of containers in the Intermediate Level Vaults will be necessary.

The APT mixed waste lead exceeds the agriculture scenario limit by almost three times and the resident scenario limit by fourteen times. This is due primarily to ${ }^{193} \mathrm{Pt}$ and ${ }^{207} \mathrm{Bi}$. The APT lead waste is not suitable for disposal in the LLWF, based on this preliminary PA. However, from the perspective of the intruder analysis, the APT lead waste could be suitable for disposal if emplacement of the waste were to be restricted to the lower layers of containers in the Intermediate Level Vaults. 


\subsection{REFERENCES}

I. U.S. Department of Energy, Radioactive Waste Management, DOE-5820.2A, September 1988.

2. U.S. Department of Energy, Interim Format and Content Guide and Standard Review Plan for U.S. Department of Energy Low-Level Waste Disposal Facility Performance Assessments, October 31, 1996.

3. WSRC, Draft Radiological Performance Assessment for the E-Area Vaults Disposal Facility, WSRC-RP-94218, Rev.1, Westinghouse Savannah River Company, Aiken, SC.

4. WSRC, Accelerator Production of Tritium, Pollution Prevention Design Assessment (U), WSRC-TR-970260, Rev. 0, September 1997.

5. WSRC, Savannah River Technology Center, Commercial Light Water Reactor - Tritium Extraction Facility Process Waste Assessment (U), WSRC-TR-96-0294, Rev. 1, November 1997.

6. WSRC, Accelerator Production of Tritium, Pollution Prevention Design Assessment (U), Appendix B, WSRC-TR-97-0260, Rev. BB, September 2, 1998.

7. PNNL, Source Terms and Dose Rates for the LTA Hold-Down Assembly, TTQP-1-084, Rev. 1, 6/10/98.

8. PNNL, TPBAR Source Term, Radionuclide Concentrations, and Decay Heat, TTQP-1-050, Rev. 2, 3/20/98

9. PNNL, Lead Test Assembly Waste Classification, TTQP-1-049, Rev. 0, June 1997

10. U.S. Nuclear Regulatory Commission, Draft Branch Technical Position on a Performance Assessment Methodology for Low-Level Radioactive Waste Disposal Facilities, NUREG-1573, May 1997

11. U.S. Environmental Protection Agency, National Primary Drinking Water Regulations, 40 CFR 141.

12. J.R. Cook and E.L. Wilhite, Radionuclide Screening and Preliminary Scoping Study for EAV Disposal of $A P T$ and TEF Wastes (U), 2/26/98.

13. J.R. Cook, Groundwater Pathway Scoping Analysis for Disposal of APT and TEF Wastes, WSRC-RP-98$00729,8 / 20 / 98$.

14. G.T. Chandler, Corrosion Evaluation of Accelerator Production of Tritium and Tritium Extraction Facility Low-Level Waste Forms and Disposal Boxes in the E-Area Vaults, SRT-MTS-98-2028, 8/7/98.

15. DOE-SR, Savannah River Site Future Use Plan, March 1998

16. R.A. Freeze and J.A. Cherry, Groundwater, 1979, Prentice-Hall, Inc., New Jersey

17. A.K., Runchal, PORFLOW User's Manual, Version 4.00, Analytic \& Computational Research, Inc., 1997

18. G.P. Flach and M.K. Harris, Integrated Hydrogeological Model of the General Separations Area (U), Volume 2: Groundwater Flow Model, WSRC-TR-96-0399, Rev. 0, 8/97.

19. R.K. Aadland, et al, Hydrogeologic Framework of West-Central South Carolina, State of South Carolina, Department of Natural Resources, Water Resources Division, Report 5, South Carolina.

20. E.A. Clark, Tritium Permeation Estimate from APT and CLWR-TEF Waste Packages (U), WSRC-TR-98$00238,7 / 31 / 98$.

21. A.A. Simpkins and W.H. Carlton, Modeling of Releases From the New Burial Ground, E Area, SRT-EST98-288, 6/16/98.

22. A.A. Simpkins, Modeling of Releases from the new Burial Ground, E Area-Additional Radionuclides, SRTEST-98-341.

23. D. M. Hamby, MAXINE: An Improved Methodology for Estimating Maximum Individual Dose from Chronic Atmospheric Radioactive Releases, WSRC-TR-94-053.

24. A.A. Simpkins, Modeling of Releases from the New Burial Ground, E Area-MEI at $100 \mathrm{~m}$, SRT-EST-98333.

25. D. M. Hamby, Verification of the MAXIGASP and POPGASP Computer Codes for Environmental Dose Assessment, WSRC-RP-94-522. 